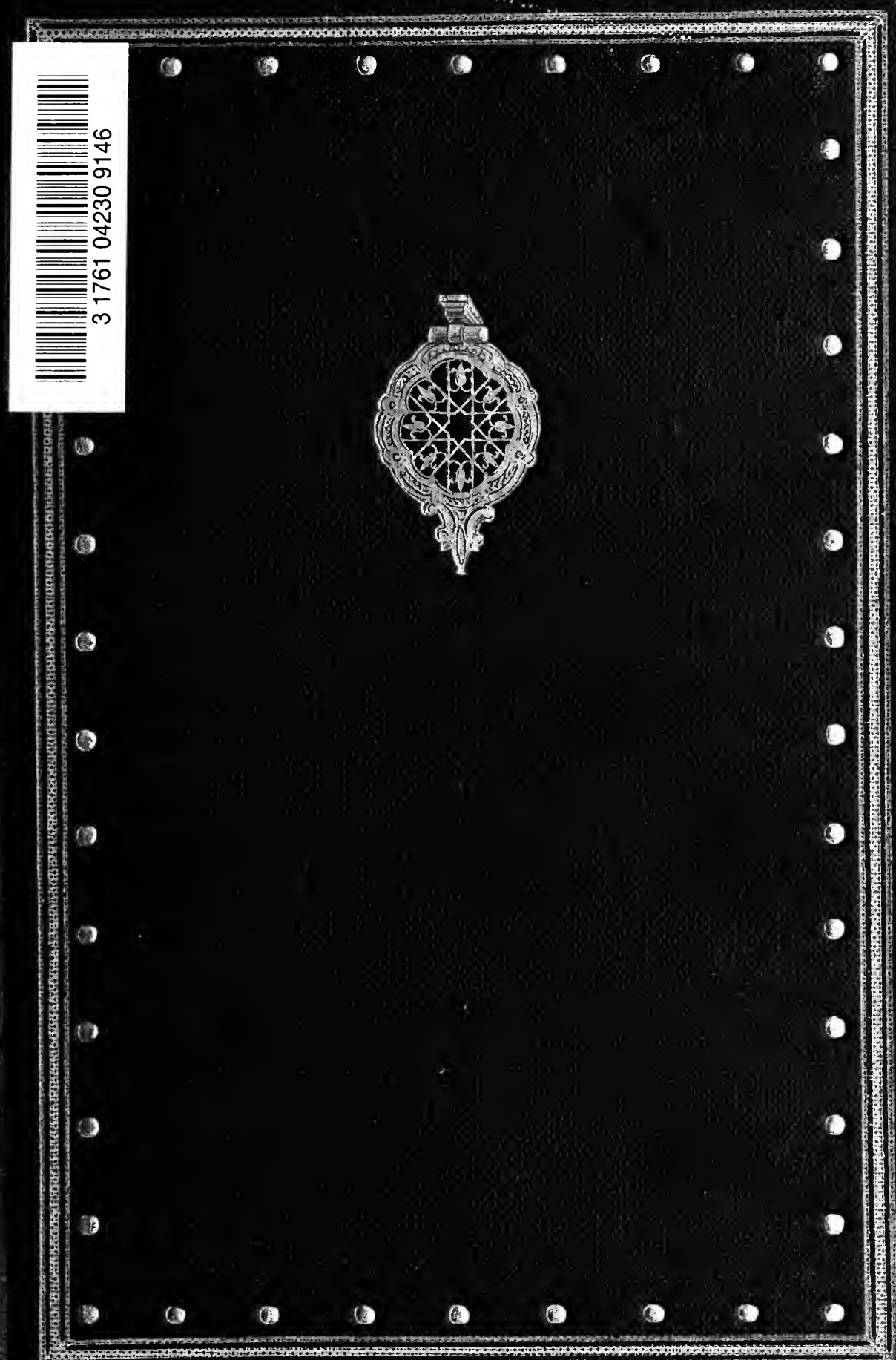


Digitized by the Internet Archive in 2008 with funding from

-. Microsoft Corporation

\section{㱠}


ABOUT ALGERIA

A LGIERS-TLEMCCEN-CONSTANTINE-BISKRA - TIMGAD 
BY THE SAME AUTHOR

LEAVES FROM A

MADEIRA GARDEN

Crown 8vo, 5s. NET 


$$
\therefore=y^{\prime \prime}+4
$$

की को -

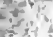

$=2-1$

:

(a)

? 


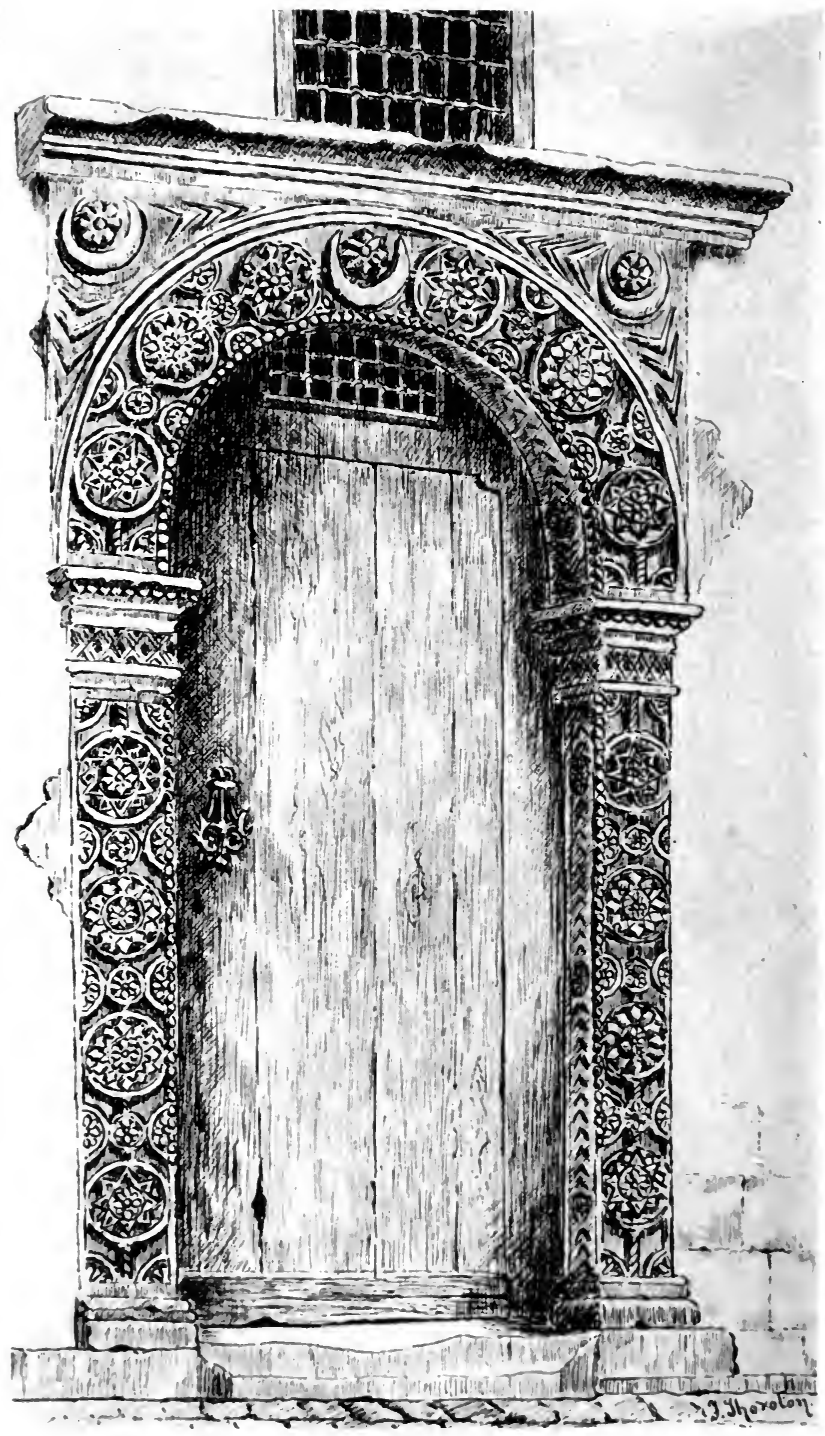




\section{ABOUT ALGERIA}

ALGIERS B TLEMÇEN CONSTANTINE B BISKRA $T I M G A D \Leftrightarrow B \quad B \quad B Y$ CHARLES THOMAS-STANFORD F.S.A. $B$ WITH A MAP AND THIRTY - TWO ILLUSTRATIONS FROM DRA WINGS BY F. DORRIEN THOROTON AND FROM PHOTOGRAPHS B B B B B

LONDON: JOHN LANE, THE BODLEY HEAD NEW YORK: JOHN LANE COMPANY. MCMXII 


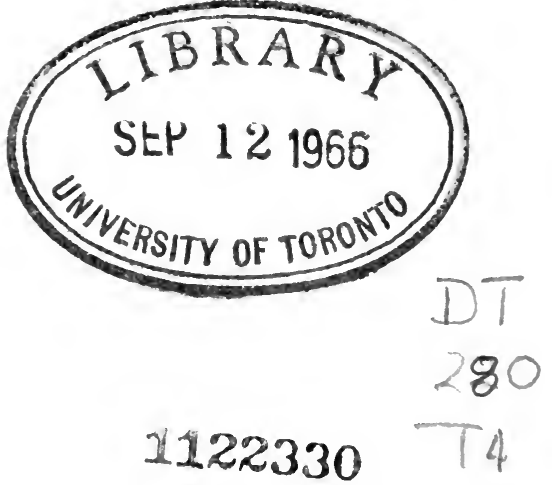

WM. BRENDON AND SON, LTD., PRINTERS, PLYMOUTH 


\section{PREFACE}

7 HE following pages are a record of impressions received from a visit to Algeria in the early months of I9I I. In a former volume I dared to ridicule the pretensions of those who, on the strength of a short stay in a foreign country and a perusal of previous authorities, undertook to enlighten the public. My chickens have come home to roost.

If I must seek an excuse for hasty conclusions I may find it in the motor-car. It has revolutionized the relations of time and space, and abolished the barren interludes of travel. It has increased fourfold the traveller's opportunities of observation. Algeria, a land of great distances and admirable roads, is especially suited to its use. And it is a country brimful of interest, historical and actual. The scholar may dig 


\section{Preface}

in the debris of the Roman and Byzantine dominions; the connoisseur revel in the relics of Moorish art; the politician contemplate the colonization of a conquered territory in the face of a subject population alien in race and religion; the ordinary traveller will be content to sip a little at each source. So have I sipped in these pages. Much that I have written will be trite to those who know the country. But perhaps I shall induce others to go and see for themselves. And on their gratitude I rely with confidence.

The reproduction here of some of $\mathrm{Mr}$. Thoroton's admirable drawings of Arab doorways may serve to lead the attention of travellers-and perhaps of the authoritiesto these interesting features of the old town of Algiers. The destroyer is busy, but here, as elsewhere, his ruinous energy makes what he has spared more precious. There are signs that his days are numbered, of the rise of a more enlightened public opinion con- 


\section{Preface}

cerning the preservation of features of antiquarian value or natural beauty. The excellent work of the Service des monuments bistoriques is bearing good fruit. At Timgad it has given a Roman City to the modern world; at Tlemçen it is safeguarding the treasures of Arab decorative art; the less important antiquities of Algiers and Constantine, and of a hundred less considerable places, should be its future care.

It is too much to expect that a trading and agricultural community should wax enthusiastic over such matters for their own sake. The point we have to emphasise is that there is money in them; that they have a very distinct and rising commercial value, easily destroyed, and, once lost, irrecoverable.

The guide-books to Algeria, in the English language at all events, are, in view of modern conditions of travel, hopelessly out of date. The motorist will, of course, provide himself with Messrs. Michelins' admirable road-book. There he is furnished with precise and con- 


\section{Preface}

densed information as to distances, surfaces, and hotels. The traveller who desires to look beyond these primary facts will find in M. Maurice Wahl's "L'Algerie" (Cinquième Edition, Paris, I908), a compendium of information-concise, logical, and complete, after the French manner; and he will regret that its usefulness is much diminished, in accordance with an unfortunate French fashion, by the absence of an index.

C. T. S.

Brighton, July, 1911. 


\section{CONTENTS}

\section{I-Araby's Daughter}

Europe and the Mediterranean-Algiers-The clash of civilizations-Things ancient and modern-The strangers' quarter-Arabs, Berbers, Moors, Jews, and others-A tale of a telegram . .

\section{II-The Corsair City}

The old town-The Arab ménage-The Penon-Barbarossa-French achievements and shortcomings -The Arab house - Christian slavery - Lord Exmouth

\section{III-New Roads and Old Cities}

Rome's successors-The Road and its influenceAlgerian highways-The motor-car and modern travel - An aqueduct - Cherchel - Cleopatra's daughter-Tipasa-The French as ColonistsViticulture . $\quad$. $\quad . \quad$.

\section{IV-A Garden and some Buildings}

Jardin d'Essai-A lost opportunity-Some suggestions - The villas of Mustapha-A model museumArab art-Its origins-Its limitations-Its significance 


\section{Contents}

\section{V-Sword and Plough}

Great events and trivial causes-The Dey's fan-

France roused-England as dog-in-the-mangerThe French expedition and conquest-ClauzelAbd-el-Kader-Bugeaud . .

\section{VI-Tlemçen the Holy}

Western Algeria--Sidi Bel Abbès-The Foreign

Legion-A city of learning - Its inhabitants-The Mosque of Aboul Hassan-Mansoura-Its storySidi Bou Medine-Oran-Spanish immigrants.

\section{VII-The City of Precipices}

Road and rail to the eastward-Constantine-Its remarkable site-Its chequered history - French Conquest-Roman remains-Fronto-The Mairie -The road northward-The Aurès $\quad$. $\quad$ i 78

\section{VIII-The Alluring Oasis}

El-Kantara-The Gateway of the Desert-BiskraIts attractions-The dancing-girls- " Hichenstown "-A garden and a vision-Railway extension-Conquering Mohammedans-Sidi OkbaThe Arab's point of view

\section{IX-The Sahara}

The desert in imagination and reality-Underground water-Artesian wells-Mozabites-TouaregsThe camel-Recent developments-Railway projects-The Army of Africa . . . 228 


\section{Contents}

\section{X-Timgad}

The Roman frontier-Lambessa-The Empire ruined by bad finance-African Emperors-The plan of Timgad-Buildings, inscriptions, and mosaicsProsperity of Roman Africa-Local patriotismThe Roman tradition .

\section{XI-A Public Library}

A romantic find-A municipal library of the third century-A Roman Carnegie-Christian Africa -The Donatists-Genseric the Vandal-Justinian-Timgad and Pompeii . . 266

\section{XII-The Road Through Khabylia}

Sétif-The Chabet pass-A fishless river-A lovely coast-Bougie-Khabylia_Greek types-Fort National

INDEX 
$-$

a. 


\section{ILLUSTRATIONS}

Algiers: Doorway in the Rue Kleber .

- Frontispiece

TO FACE PAGB

" Carved Stone Doorway in the Native Quarter . $\quad \cdot \quad$. $\quad$ I 7

" Doorway in the Rue de la Kasbah . . 24

” Moorish Doorway, Rue Porte Neave . 35

" Marble Doorway, Rue Bruce . . $3^{6}$

” Doorway, Rue Medea . . . $\quad 48$

” Doorway in the Rue Ben-Ali . . 54

" Entrance-door of the Mosque, Rue de la

Marine . $\quad . \quad$. $\quad .68$

Cherchel : the Aqueduct . . . . 90

Algiers : Garden of the Hotel St. George . . 104

" Fountain in the Kasbeh . . . 108

" Dragon Tree in the Garden of the Hotel

Continental . . . . II2

" Fountain, Rue de l'Intendance . . II 8

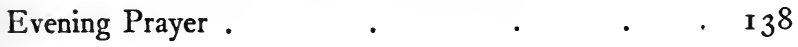

Caravan of a Caid $\quad . \quad$. $\quad . \quad$. I4I

Tlemçen : the Minaret of Agadir . . . I53

The Walls of Mansoura . $\quad$. . . 164

The Tower of Mansoura . $\quad$. $\quad$ r 169 


\section{Illustrations}

Sidi Bou Medine : the Bronze Doors

TO FACE PAGE

Constantine

Zouaves

El Kantara

Old Biskra

Biskra : Statue of Cardinal Lavigerie .

Sidi Okba : a Street

The Outskirts of the Sahara

An Artesian Well

A Native Well .

A Caravan

A Street at Timgad

Timgad: Arch at Trajan .

" The Public Library

- 172

- $18 \mathrm{I}$

- 191

. 201 


\section{ABOUT ALGERIA $A L G I E R S-T L E M C E N-C O N-$ $S T A N T I N E-B I S K R A-T I M G A D$}





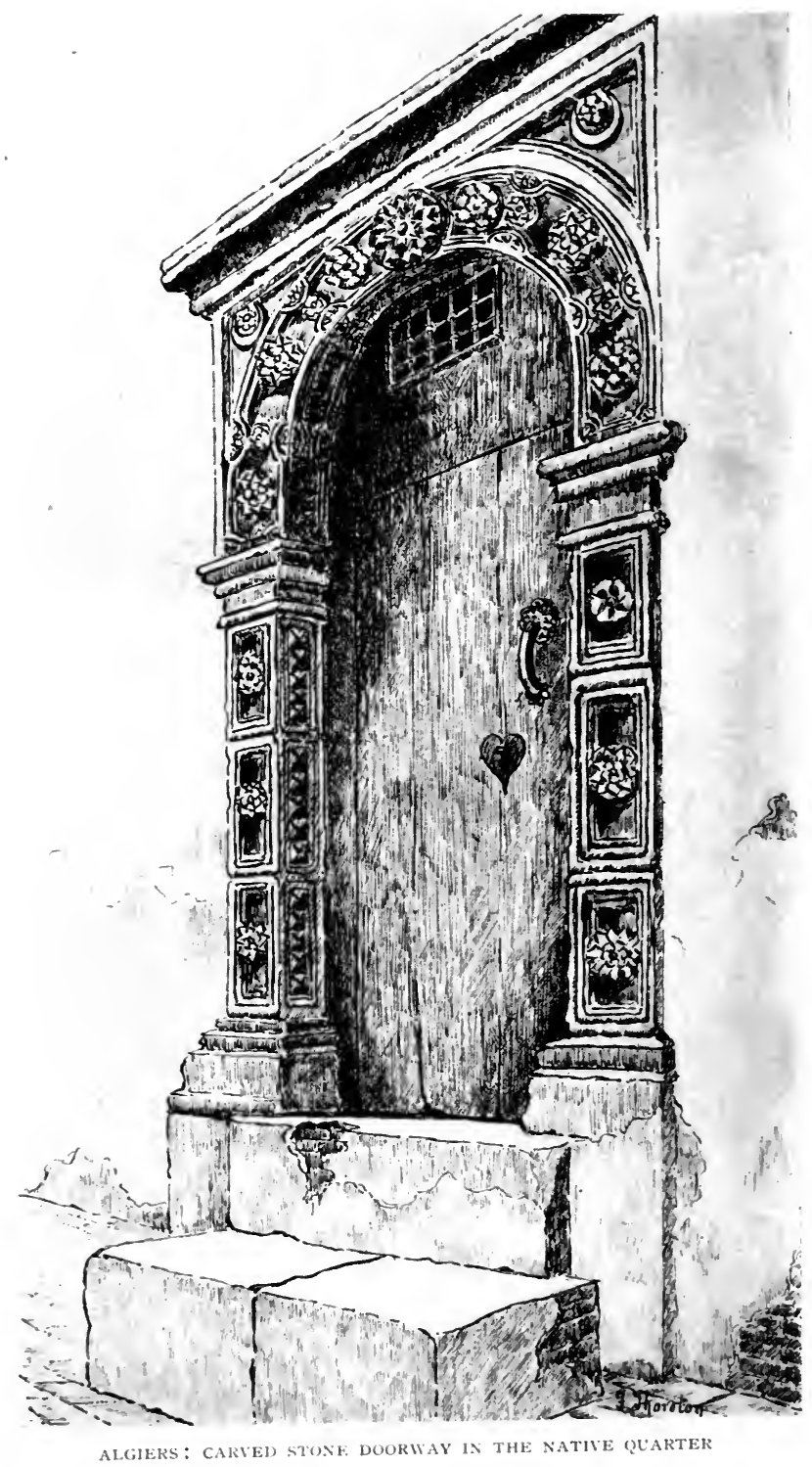




\section{ABOUT ALGERIA}

\section{$I-A R A B Y^{\prime} S$ DAUGHTER}

Europe and the Mediterranean-Algiers-The clash of civilizationsThings ancient and modern-The strangers' quarter-Arabs, Berbers, Moors, Jews, and others-A tale of a telegram.

"E'en now the devastation is begun And half the business of destruction done."

Goldsmith.

OME of the ashes of the Roman Empire have been recovered. The Mediterranean is once more a European lake. The Turk indeed still holds its eastern shores; the amazing Sultanate of Morocco yet persists in the west; strong, after the manner of Barbary for centuries, in the jealousies of Europe. Yet the Turk, while maintaining his assertion of the Unity of the Godhead, which divides him from Christendom, is, nevertheless, in other ways almost to be accounted a member of the European 


\section{About Algeria}

family; and even in the vigorous days of the Empire the wild tribes of the Greater Atlas recked little of the might and majesty of Rome. These are the limitations; our concern is with the achievement, and especially with the fertile country, once Rome's granary, now after a thousand years of neglect and abasement restored to the orderly uses of civilized man. We are to visit a land unsurpassed in the variety of its historical vicissitudes, and strewn with the stones of many empires; a land where to-day a European nation, cherishing, perhaps more than any other, Roman traditions in its law and polity, controls by force of arms and of character a vast and heterogeneous population, previously united only in its submission to the brooding blight of Islam.

"The grand object of travelling," said Dr. Johnson, " is to see the shores of the Mediterranean; on those shores were the four great empires of the world; the Assyrian, the Persian, the Grecian, and the Roman. All our religion, almost all our law, almost all our arts, almost all that sets us above savages has come to us from the shores of the Mediter- 


\section{Araby's Daughter}

ranean." The Doctor's aspirations were doubtless confined to its northern shore. If he had indiscreetly placed himself within the jurisdiction of the Dey of Algiers or the Bey of Tunis he might have found his value appraised on a basis different from that which prevailed at The Club, and in default of ransom have been set to uncongenial tasks. We are more fortunate in our generation.

To men trained in the traditional scholarship of English schools and universities certain places of the earth are holy places. The Acropolis of Athens, the heights and harbour of Syracuse, the Roman forum; perhaps in a scarcely less degree, Constantinople seen from the Bosphorus; - these stir to life sentiments born of youthful struggles and enthusiasms, but buried beneath a load of years crowded with other interests. Such sentiments may even prevail over those which attach to more recent history and national predilections. The approach by sea from the Atlantic to the Straits of Gibraltar is an experience to move the most indifferent; to an Englishman a very moving experience. He has passed Cape St. Vincent, with its undying fame, 


\section{About Algeria}

and the Rock is ahead, with its triumphant symbolism of his country's world-power. Across the straits lies the rocky coast between Tangiers and Ceuta, a rampart of that vast continent, the last home of mystery, which has played so great a part in the lives of the present generation of Englishmen. And the Rock itself, detached, impregnable, is rich in English memories from Blake to our own day.

Yet to him who has preserved some shreds of his classical learning, the passage from the Atlantic to the Mediterranean has a still deeper significance. It marks the separation of the old and the new worlds. At the Pillars of Hercules the old world ended ; they guarded the threshold of the unknown. On the inland sea within were cradled the civilizations on which our own is mainly based-Hebrew, Hellenic, Roman. Perhaps we may wonder at their limitations, especially at the comparative inefficiency of Rome in maritime affairs. If Rome with her vast resources had owned a spark of the naval enterprise of ancient Phœnicia or modern Britain ; if she had spent on the sea a tithe of the energy she exercised on land-exhibited nowhere more completely 


\section{Araby's Daughter}

than in that Northern Africa to which we are bound-the history of the world might, indeed, have taken a different course. But it was reserved for the great awakening of the fifteenth century to probe the secrets of the mysterious Atlantic, and to throw open vast fields for conquest and colonization to the European races. And when through the gathering darkness we look back to the twin peaks, we recall the legend of the two dragons guarding the entrance to the Garden of the Hesperides, and wonder if it was invented by ancient mariners to cover their lack of enterprise.

Many Mediterranean cities present a fair prospect to him who comes by sea, especially in the pearly radiance of the Mediterranean dawn. Algiers surpasses all. The steepness of the hill-side which it fills and its own white brilliancy give to it a special distinction. Many writers, following a leader as sheep that have gone astray, have compared it to the tiers of seats rising one above another in a Greek theatre-a fanciful and baseless comparison. There is no such ordered arrangement. The straight lines of modern houses 


\section{About Algeria}

enclose a central mass of strange irregularity, so confused that from a distance it has the semblance of a heap of ruins. This is the remnant of the Arab city, a swarming antheap of native life, filled with strange and savage memories of the, astonishing pirates who were through centuries, and even until living memory, the scourge of Christendom. The sea front has entirely lost its ancient aspect; its long line of symmetrical houses, with its Boulevard de la République, and its Boulevard Carnot, recalls Palermo or Messina. And stretching south and east along the hills which encircle the bay the city's suburbs seem to have no end; white houses gleam amid dark foliage and splendid villas crown the heights.

The first view of the streets is something of a shock and a disappointment. We have heard of the ancient Arab city, we have seen photographs of narrow lanes with quaint Moorish houses almost meeting over the wayfarer's head; and yet we find ourselves driving at a hand gallop through wide, modern streets, with their normal garniture of tramways and motor-cars. An occasional snow- 


\section{Araby's Daughter}

white mosque, a public building or two of Arabesque style, suggest the Orient; in other respects the streets are those of a very prosperous and busy modern French town. It is easy to see that Algiers enjoys a municipality anxious to be in the forefront of civic progress; that $M$. le Maire is determined that his city shall not be ashamed to look Marseilles and Nice in the face; and that as the native and the stranger wander incuriously through the streets, earnest committeessanitary committees, waterworks committees, lighting committees, tramway committees, committees for the regulation of everything that can be regulated-are seated in upper chambers eagerly concerting measures for their welfare. And it may even be that civilization is sufficiently advanced for a Ratepayers' Association to be keeping a bilious eye on the proceedings of its chosen representatives, and endeavouring to solve the eternal problem-Quis custodiet custodes?

It will be recalled that the immortal Tartarin suffered a similar disenchantment. He had figured to himself an Oriental town of fairy mythology, holding a middle place between 


\section{About Algeria}

Constantinople and Zanzibar-" il tombait en plein Tarascon." But that soaring and romantic spirit refused to be bound in the chains of the commonplace, and, following humbly in his wake, let us strive to see an Arab beauty beneath the veil of our neighbour in the tram-car, and to hear in the rumble of a distant train at night the roar of ravening lions.

The hasty and inconsiderate modernization of an ancient and historic town such as Algiers suggests serious considerations. The process of destroying what is noteworthy for age or beauty in the name of improvement would seem to be generally accepted as one of the conditions of progress. Cities and towns, it is not unnaturally held, are not museums or curiosity shops; men are massed in them to gain their livelihood, or to pursue their pleasures. The antiquaries, those who admire and study the works of the past, because they are the works of the past; the naturelovers, who "cultivate the beautiful without extravagance"; these are an insignificant section drawn for the most part from that hard-working class which is known to poli- 


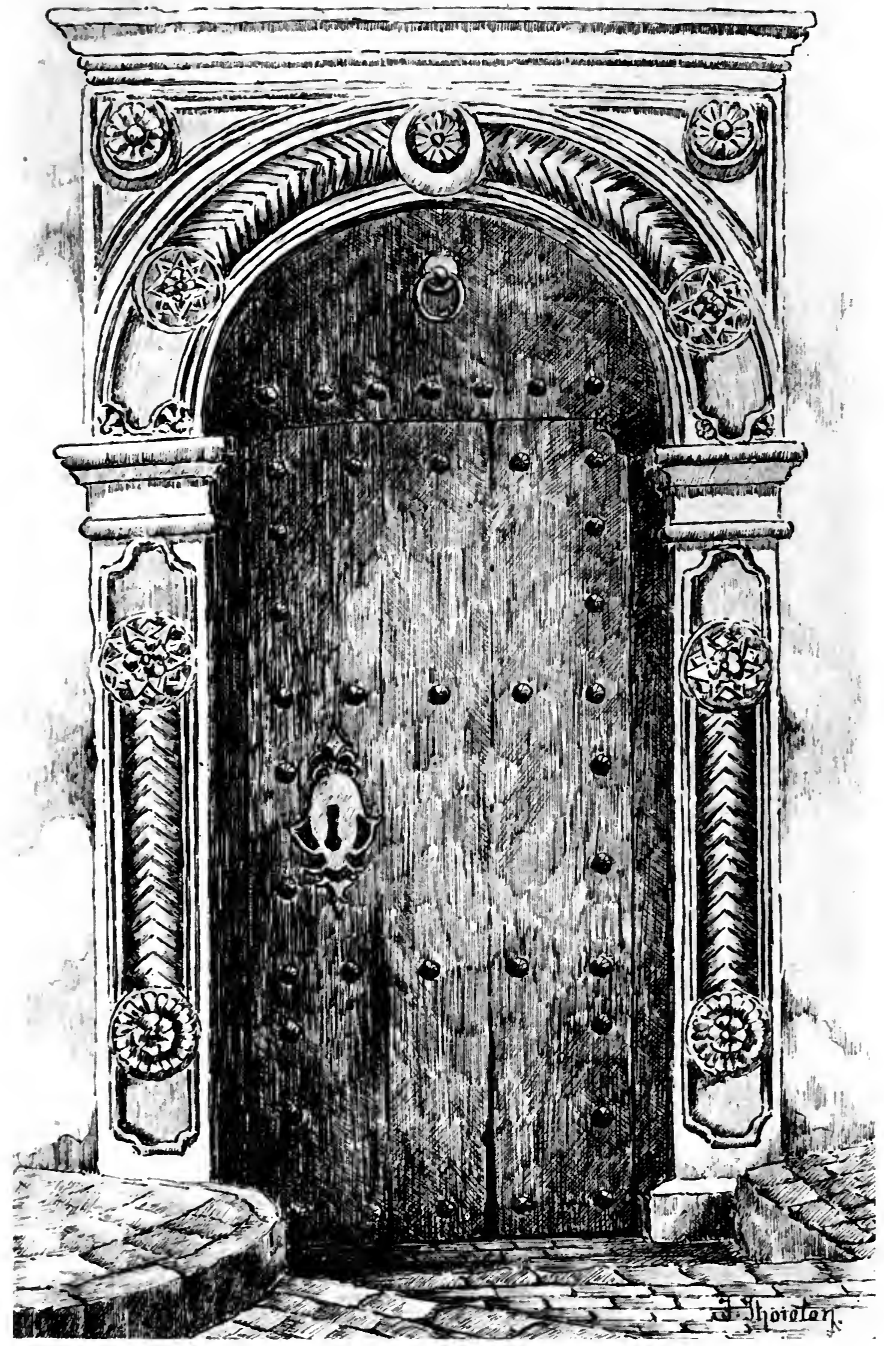

ALGIERS: DOORWAY IN THE RUE DE LA KASBAH 
हर

$\Rightarrow$

ipe

$7 n=4$ 


\section{Araby's Daughter}

ticians as the idle rich. Their protests are of no great avail. Governments, if well-meaning, are lukewarm; local authorities, eager to be in the municipal movement, are commonly apathetic as regards the claims of mere ancientry or natural comeliness. Of what the modern Italians are doing to desecrate Rome and despoil Florence it is difficult to speak with patience. And it is the work of their own fathers that they are pulling down or vulgarizing. The conditions here are quite different, and the reforming zeal of the French so far less flagrant. They have replaced by their own civilization what they regard as the barbarism of a conquered race; they wanted the city of that race to live in, and they found it in every way repugnant to their tastes and unsuited to their needs. The soldiers began the work of destruction; soldiers destroy ruthlessly in the day of battle; but the persistent waste of the horde that follows after-the engineers, the architects, the speculative builders, the railway constructors, and the great industrial companies-is infinitely more damaging in the long run.

And what are we that we should cast a 


\section{About Algeria}

stone at the French? How much have we spared of old London and its suburbs? How much of the urban beauty and rural charm of England did our rude forefathers of the nineteenth century wantonly and light-heartedly destroy? When have railway projects or proposed public works been stayed on æsthetic grounds? Do the station and bridge at Charing Cross lend dignity to our great river ? And, to look further afield, to what fate have we, masters of the Nile, condemned Philae?

In this changeful North Africa succeeding conquerors have imposed their civilizations and their works upon those of the conquered in a manner which has scarcely any parallel in Europe. Carthage destroyed, Rome came in her might and built a hundred cities, conducted water, brought huge areas into cultivation, and made roads after her manner; and in due time overthrew her own ancient altars in zeal for a new faith. In the age of her decrepitude Byzantium strove to maintain the Pax Romana, to curb the Vandal usurpation and the Arian schism, and to keep the aspirations of the indigenous population within bounds. All went down in a day before a 


\section{Araby's Daughter}

troop of Arabians who rode as conquerors from Egypt to the Atlantic. Islam followed in their wake. The civilization derived from Europe disappeared; the watercourses were broken, the desert resumed its sway, and the stones of Roman temples and basilicas went to build the mosques and villas of the visitors. For twelve centuries the creed of Mahomet held dominion; Europe was busy with its own affairs, and endured the insolent depredations and exactions of the Deys with scarcely a serious attempt to suppress them. But at length the cup was full. An English fleet struck the first blow; a few years later France took the subjugation of Algeria seriously in hand; and to-day European civilization is once more paramount in the ancient provinces of Rome.

There are hotels in the town, frequented, perhaps, more by commercial than by leisurely travellers, and the visitor will probably prefer to lodge himself at Mustapha Supérieur. Here, if he chooses a house in a good situation, and obtains a room with a southern aspect, he may feast his eyes untiringly on a scene of great beauty. At his feet lies the bay where 


\section{About Algeria}

Charles V landed his ill-fated expeditiona shallow bay in which often the waves breaking afar out roll to the land in foam. Towering above the lesser hills which front its opposite shore are the snow-clad mountains of the Djurjura range, guarding the highlands of Khabylia, and glistening as if with crystals in the strong southern light. All around, on the well-wooded heights, are countless villas, of high and low degree, almost all of dazzling white, the whiter for the sombre foliage of cypress and stone pine and olive in which they are set. Perhaps no city of the earth possesses a lovelier suburb. The Englishman will find himself quite at home. The villas and the hotels are to a great extent occupied by his compatriots; and the institutions of his country are fitly represented by an Anglican church and a nine-hole golf-course. If he should be led to climb through an aromatic wood of eucalyptus to the home of "le golf," and be able to remove for a moment his eye from the ball, he may enjoy a most glorious prospect. The snowy Djurjura of the southeast finds a rival in the Lesser Atlas to the south-west, and between the two lies a billowy 


\section{Araby's Daughter}

champaign of cultivated and wooded hill and plain. If his preconceived notions of Algeria, like the great Tartarin's, are dominated by the Sahara, if of Africa he knows only the river banks of Egypt and the rolling veldt of the South, he will perhaps recognize once more that Africa is ever the continent of surprise.

To return to the town. If at first sight the aspect of the French quays, and the modern streets, shops, and boulevards, destroys pre-existing illusions, ample amends are made by the colour and variety of the crowds which frequent them, a very colluvies gentium. Jews, Turks, infidels, and heretics jostle the faithful on equal terms; men and women sprung from very diverse stocks in Africa, Asia, and Europe, impartially and to all appearance fraternally throng the pavements and the public conveyances. The eye is dazzled by the combination of European fashions and smart French uniforms, with the outlandish aspect of Zouaves and Spahis, the white-robed dignity of the stately Arab and the rich colours of the impassive Turk. It is only after a time that one is able to 


\section{About Algeria}

separate them into classes, and to perceive that the native inhabitants fall naturally into further subdivisions.

The greater part of the inhabitants of Algeria, Tunisia, and Morocco, known collectively to Arabs as the Maghrab, and to our forefathers as Barbary,-an island girt by sea and desert, - still represents those original peoples who preceded the Phœnicians and the Romans. They have endured and survived many conquests, for the most part accommodating themselves to the conquerors' institutions and religions. The Arabs called them Berbers,-the origin of the name is doubtful. Being to-day Arab in all but descent,-and very mixed in that,-they are described in common parlance as Arabs.

In A.D. 647, when the Sultan Othmar decided to attempt the conquest of North Africa, it was still under the rule of the weak Byzantine Emperors, Gregorius being its governor. Othmar collected 20,000 of the élite of the Arab forces, and added to them a similar number of Egyptians. This small army performed a brilliant feat of arms. Advancing against Gregorius, who was stationed 


\section{Araby's Daughter}

at Sbeitla (in Tunisia), the Arab leader, Abdulla Ibn Säad, offered the Christian leader terms: that he should embrace Islam and render tribute to the Sultan. These being declined, a fierce battle raged for several days. Gregorius was in command of 120,000 men, but they were probably no match for the disciplined Arabs. It is said that his daughter, a maid of incomparable beauty, fought at her father's side, and promised her hand and a fortune to whoever should kill Abdulla. This seems to have been a somewhat ill-advised proposal, for Abdulla, hearing of it, offered the same reward to the slayer of Gregorius. After several days of desperate fighting the Christian host was utterly defeated. Gregorius fell in the final onslaught, and his daughter was bestowed on Ibn EzZobeir, who had slain him.

So ended the first Arab attack on Northern Africa. It had momentous consequences. Not only did it bind to Islam for twelve hundred years the provinces which for centuries before had been Christian and an appanage of Europe, but it paved the way for the Arab invasion of Spain. 


\section{About Algeria}

Abdulla's raid was shortly followed by other military expeditions. Eighteen years later Sidi Okba, having established a permanent government, pursued his course through what is now Morocco to the Atlantic Ocean. In order to complete the downfall of Christianity, a special tax was imposed on Christians, a leaf out of the book of Constantine the Great, who, in order to ensure its spread through the Roman world, had ingeniously enacted that no pagan master should own a Christian slave. The tax had the effect desired, and the whole population embraced the faith and rule of Islam.

Four hundred years later a great Arab immigration took place. The brigand tribes of Hillal and Soleim being driven from Arabia into Egypt, speedily found their way thence into Northern Africa, which they overran like a flight of locusts. From these nomad hordes are descended in the main the Arabs of to-day.

If the true Arabs only represent a fraction of the total Mohammedan population, variously estimated at a third and a sixth, they have imposed on the remainder their 


\section{Araby's Daughter}

language, their religion, their institutions, and their customs, with the result that in a sense all are Arabs, though not of race. The purebred Arab is of an aristocratic type-tall, thin, muscular, and of dignified carriage. His narrow and retreating forehead indicates no great brain power; this feature is sometimes so marked as to give an aspect of semi-idiocy.

A rigorous childhood ensures the survival of the fittest; the Arab children are left to themselves, naked in heat and cold, in sun and rain and frost, and only the hardiest reach manhood. The result is seen in the finely tempered physique of the race, in the Arab's extraordinary powers of endurance, and in his disregard of hardship and suffering. Whole tribes are infected with what are called the diseases of civilization; typhus and smallpox sometimes blaze like a flame among them; the Arab scorns precaution or cure, and lives or dies with indifference.

As becomes his aristocratic traditions, he prefers war to peace, and plunder to work. His nomad life, which accords with these tastes, is probably an accident forced upon him by the climatic conditions of the country. 


\section{About Algeria}

His wealth depends on his flocks and herds, his very existence is tied to the necessity of finding pasture for them. New ground has ever to be sought, different altitudes being visited according to the season and the period of rainfall. For a people of filthy habits a nomad life has many advantages; the constant change of camping-ground counteracts in some degree the want of sanitary conditions.

According to European ideas the Arab is a barbarian, sans foi ni loi. With some limitations, as in his hospitality, although he will not scruple to rob his guest next day, he has no sense of honour, and aims not at telling the truth, but at telling a lie adroitly. His women are mere beasts of burden, absolutely at the mercy of their lord. A whole world of progress lies between the Frenchman who works his fingers to the bone to give his daughter a dower, and the Arab who sells his to the highest bidder. And in love as in life the Arab is often a nomad, as the desert towns bear witness. But as he stalks haughtily through the streets of Algiers, he is an attractive and interesting figure. And who may measure his disgust at the triumph of the infidel ? 
प⿺ 


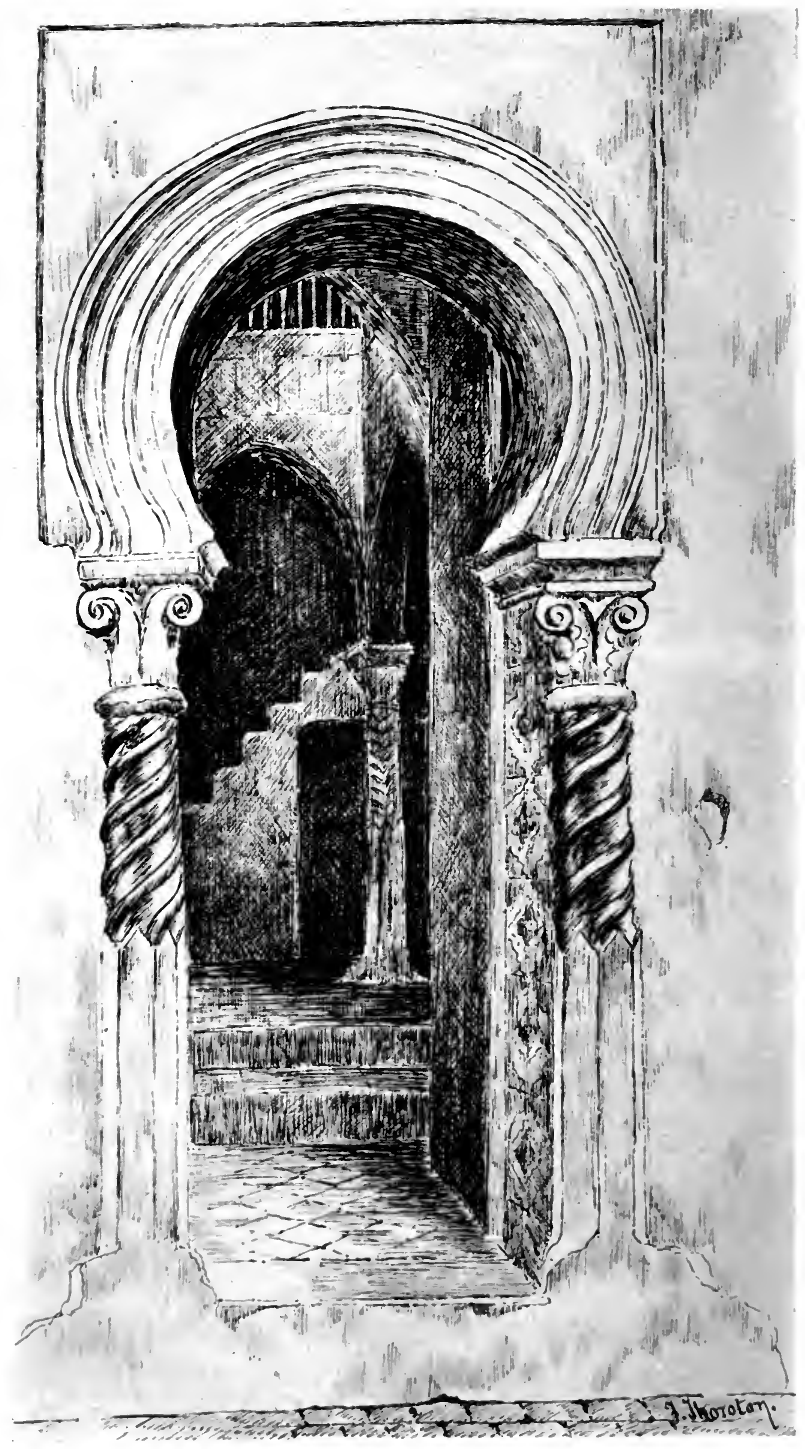

ALGIERS : MOORISI DOORWA, KLE PORTE NEUYE 


\section{Araby's Daughter}

It is impossible to contemplate this strange being, moving among a medley of races, without wondering what the future has in store. Will the Arab live apart, as the Jew has often lived apart, or can he be brought to assimilate the ideas and methods of his conquerors? At present he seems dazed; his civilization founded on war has failed him in war. It is useless to think of France converting him to Christianity; you cannot convert a man to a faith you have abandoned yourself. And his religion, absolute and absorbing-not of his life a thing apart, but his whole existence-seems to oppose an impassable barrier to European influences. You cannot reason with a man under a spell. Yet it is impossible to suppose that the present situation can continue indefinitely, and this is fully recognized by the French themselves. The only solution so far attempted is in some kind of education for Arab children. Our problem in India and Egypt is a less urgent one; we have not colonized either country as the French have colonized Algeria.

The sang pur of the original inhabitants, called Berbers by the Arabs, is most fully 


\section{About Algeria}

represented by the Khabyles, who inhabit the mountainous tracts of the littoral, both east and west of Algiers. They were Christian under the later Roman rule, but adopted the religion of Islam after the Arab invasions. Otherwise they have little in common with the later comers; physically they are more nearly allied to the races of Southern Europe. Living in their mountain fastnesses they have retained their own customs and institutions, some of which are said to show a trace of Roman influence. Their women are not veiled, and occupy a much more independent position than is usual in Mohammedan countries. Their men, to be seen in the streets of Algiers, may frequently be distinguished from the Arabs by their fair complexions, blue eyes and reddish hair. They have no inclination to a nomad life, and are naturally industrious, freely offering their labour to the French colonists. They would seem to present a more likely field for the spread of social progress according to European ideas than does the lazy indifference of the Arab; but in their case, too, religion is a bar. 


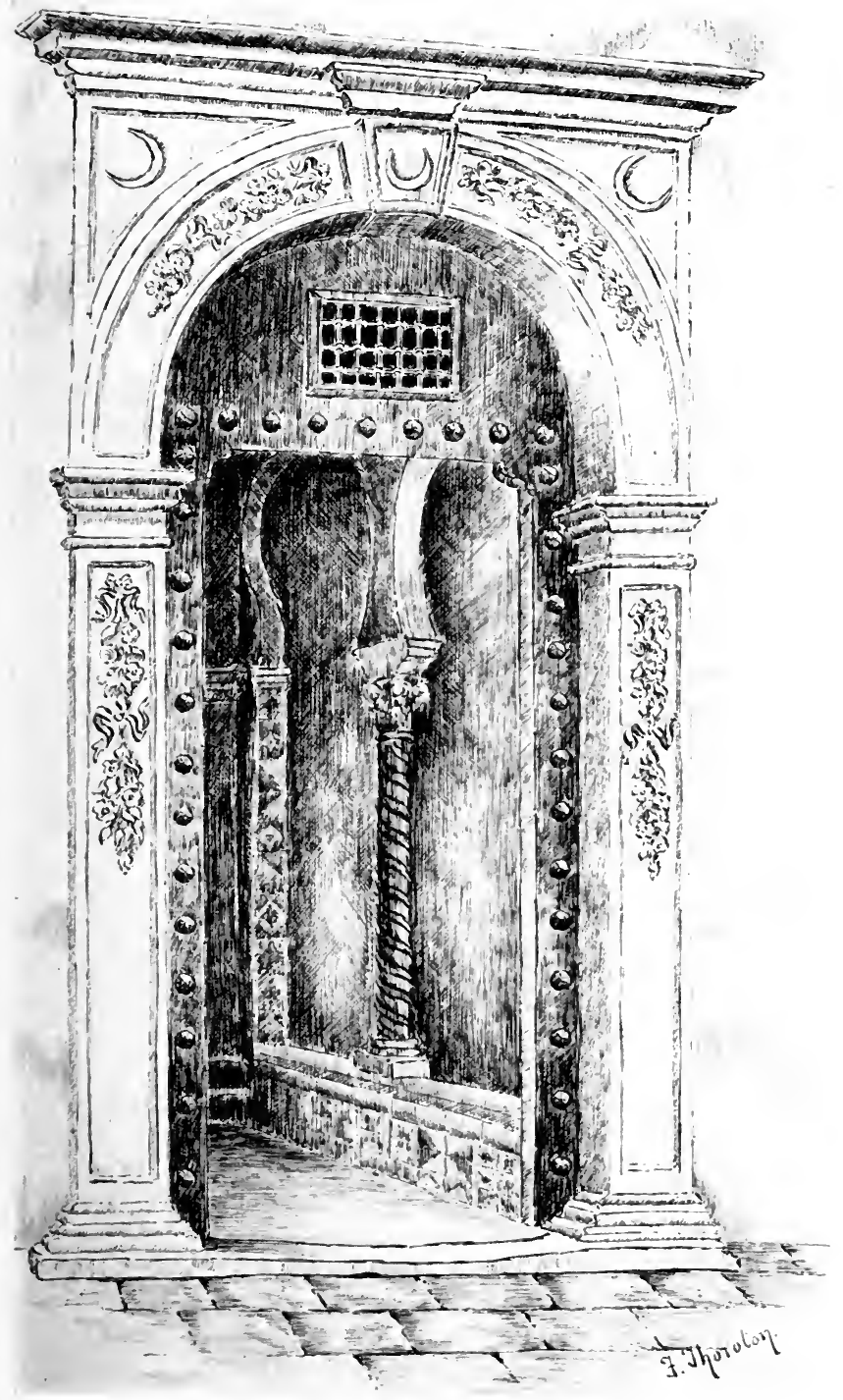

ALGIERS : MARBLE DOORWAY, RLE BRUCE 


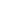




\section{Araby's Daughter}

The Mohammedan townsfolk, chiefly engaged in commercial pursuits, are called Moors, a name which has no connection with Morocco. Chiefly Arab or Berber in ultimate descent, there is among them much admixture of Turkish and European blood. Their somewhat effeminate appearance exhibits the influence of generations of town life. They affect brightly coloured clothing, embroidered waistcoats and voluminous trousers fastened at the ankle. They deal largely in embroidery, perfumes, and fancy articles, and may commonly be seen lolling in their little shops in attitudes of exaggerated indolence and unconcern. The Moorish women, like those of the Arabs, are veiled; a white linen handkerchief is tied closely across the nose, leaving the eyes visible, and perhaps somewhat heightening their effect. A white shawl, called a baik, is thrown over the head and extends to the knees or lower; the legs are encased in very voluminous trousers tied at the ankles, and setting in a way which gives them the appearance of being stuffed full. Altogether a very ungainly costume. But even so they are less wanting in dignity 


\section{About Algeria}

than the middle-class European women decked in a travesty of a mode which is itself absurd. The veiling of all Mohammedan women for the last twelve hundred years is due to the jealousy of the prophet of his young and beautiful wife Ayesha.

Since the decree of 1870 , which constituted them French citizens, the Jews have gradually ceased to wear a distinctive dress, and have become, as far as outward semblance goes, merged in the European population; but their physiognomy bewrayeth them. It is, however, as far at least as the men are concerned, of a less marked type than that of the German and Russian Jews, with whom we are more familiar; and, possibly from some admixture of Arab and Spanish blood, has an air suggestive of better breeding. The Jews have existed in Algeria from early times; according to tradition since the fall of Jerusalem. It is certain that the first Arab invaders found many Jewish colonies which had made numerous proselytes among the indigenous population. But the modern Algerian Jews are probably derived in the main from the Jews who were expelled from Italy in $\mathbf{1 3 4 2}$, 


\section{Araby's Daughter}

and from the emigrants from Spain in the fourteenth and fifteenth centuries. These Spanish Jews, better instructed and more cultivated than their African brethren, have exercised a dominating influence, exhibited to-day in their names, their customs and their language. The Jew of the South is scarcely to be distinguished from the nomads among whom he lives.

The Jew will go to any country, and live under any government; and he can make a living anywhere, except, it is said, in Aberdeen. $\mathrm{He}$ has been trained for countless generations to endure the restraint of princes and the buffets of outrageous fortune; but probably at no time and in no place has he had to put up with such treatment as was commonly meted out to him by the Deys of Algiers. Habitually subject to every kind of indignity, he was liable on the smallest provocation to be put to torture and to death. If he raised a hand to the striker the hand was lopped off. "But," said one of them to an English traveller, "look what a lot of money we make."

Profits may no longer be what they were, but the ancient race has ceased to quail 


\section{About Algeria}

before the oppressor. It is indeed not slow to exhibit the contempt which it was long forced to conceal. A little Jew entered a railway carriage in which every seat was taken but one, and over that sprawled a big Arab, who showed no intention of making room. The Jew pushed him aside with scant ceremony, whereupon the Arab turned and said, "Est-ce que vous desirez me manger ?" "Vous manger? Moi ?" replied the other; "je suis juif." The refined insult of this reference to Jewish rules of diet was doubtless lost on the barbarian, but it is a happy illustration of the passing of the old order.

In Algeria the Jews number about 70,000, or in the proportion of one to six of the European population. Since their admission to French citizenship they appear to have performed the civil and military duties attaching to it in the most exemplary manner. This has not prevented the rise of a very strong anti-Semitic feeling among the European immigrants. It is based partly on the objection to the Jews which is felt in other countries, on the fact that they toil not, neither do they spin, but that by commercial 


\section{Araby's Daughter}

arts they grow rich where others fail, and are able to make more money in five days than "Christians" can in six. This is appreciated, it may be, with especial force in a new colony, to which adventurous spirits resort in hope of fortune, only to find that every avenue is already closed to all but Jewish enterprise. Partly this animosity is due to local causes, to the solidarity with which they have used their electoral privileges, with a view, it is said, to support their own interests, rather than for public objects. It will be recalled that in 1898 , at the instigation of the notorious Max Régis, a mob composed of the turbulent elements always present in Mediterranean towns attacked and pillaged the shops and warehouses of Jewish traders in Algiers. This tribulation, however serious in itself, must have seemed comparatively slight to a race which remembered the rule of the Deys. And the crisis past things have settled down again. An agitation for the abrogation of the rights of citizenship granted in 1870 still exists, but it is unable to produce serious grounds in support of such an extreme step. To an observer it would appear that the 


\section{About Algeria}

commercial and financial enterprise of the Jews must be of immense advantage. Algiers itself is booming. Mr. Lloyd George's mouth would water at the rise in the value of suburban land from a few pence per metre ten years ago to more than as many francs to-day; and building is progressing in all directions. The command of capital which the Jews with their international connections possess is almost certainly an important factor in this prosperity. And the decline of credit in England, the fear of spoliation by predatory politicians, from which its capitalist classes, rightly or not, are suffering, may be having unsuspected results in assisting the development of other countries.

Another race of traders will attract the attention of the observant stranger. Of heavy build, flat-faced, broad-nosed, and thicklipped, the Mozabites have nothing in common with the physical qualities of the Arab. They represent a section of the original Berber inhabitants; although, it may be from the different conditions under which they have lived for many centuries, their appearance bears no great resemblance to that of their 


\section{Araby's Daughter.}

Khabyle connections. They inhabit a far country, the district of El-Mzab, in the most arid part of the Sahara. By persevering toil they have turned this inhospitable region into a garden; have dug wells and created a complicated system of irrigation. They are no less active as traders than as agriculturists. They have established markets in their own oasis, and frequent others throughout the Sahara. A considerable portion of the tribe has long lived in Algiers, being encouraged by the Deys. They have almost a monopoly of certain of the more humble trades; they are especially butchers and greengrocers.

The Biskris, a very low-class Berber tribe from the neighbourhood of Biskra, are the water-carriers and scavengers of the city. They form picturesque groups around the fountains in the Arab quarter. Their dark complexions suggest a considerable admixture of negro blood. The true negroes are also numerous, and with their alert and smiling faces offer an agreeable contrast to the sombre impassiveness of the Arab. As elsewhere, they do much of the hard work of the country, as masons and workers on the roads and railways. 


\section{About Algeria}

Negresses are employed as servants, and especially as masseuses in the Moorish baths.

Such, mingled with Frenchmen, Italians, Spaniards, Maltese, and a sprinkling of almost every European race, are the numerous types of diverse humanity which the streets of Algiers everywhere present. In so rich a scene the artist will find fruitful sources of inspiration, both of form and colour; the ethnologist will have scope for studying the features and carriage of different races, and for tracing the effects of their not infrequent intermixture; to the politician it will all give furiously to think. During the last century or two a large portion of the Mohammedan world has fallen under Western dominion. France, like England, has acted on the Roman principle, parcere subjectis et debellare superbos, but neither has succeeded in infusing the conquered races with the ambition of citizenship, as Rome did. Their attitude at best seems to be one of sullen acquiescence in the inevitable, at worst that of a hunted beast who waits his opportunity to spring. And the most incurious tourist will not escape a certain wonder at the strange 


\section{Araby's Daughter}

and varied inhabitants of a city so near his home that he may read his Monday's "Times" on Wednesday afternoon.

To outward appearance Algiers is a busy French town. But when we come to probe below the surface we find that the Golden East, with its leisurely and slipshod methods, holds us in fee. The mere sending of a common telegram is no light matter. I desired to telegraph five words to an inhabitant of the city of Funchal in the island of Madeira. I took the despatch to a branch office at Mustapha, officered by female clerks. It caused some commotion. The young women laid their heads together, pored over several tattered volumes, and finally informed me, with a certain touch of commiseration, that the charge was four francs and fifteen centimes a word. Now as the charge from London is one shilling a word, this was obviously too much. What visions of Madagascar or Macao they had conjured up I know not; they are, I believe, both islands, both, like Macedon, Monmouth and Madeira, have M's in them, and both are distant enough to justify some such charge. I tried to point 


\section{About Algeria}

out that Madeira does not ride in such remote seas, but to no purpose; and wearily I betook myself to the chief post office. This is a magnificent building in the finest style of neo-Arab art, glorious within and without. It is agreeable to find that the French authorities are now erecting great buildings in the local style, instead of reproducing the monotonous ugliness of the Third Empire. If only the Boulevard facing the harbour could be so transformed, the view of the port would indeed be worth looking at. In this resplendent Temple of Mercury one youthful clerk is considered sufficient to receive the telegrams of Algiers. He took my paper, counted the words backwards and forwards, and said airily, "Un franc." I inquired whether he meant for each word, or for the whole. He replied for the whole. Now he was evidently erring on the side of moderation, as his sisters had erred on the side of excess. I protested that I would not pay so little. Books were consulted, higher officials interviewed, many shoulders shrugged and many palms spread, but to no purpose. Meantime in a somewhat impatient queue the telegraphic 


\section{Araby's Daughter}

business of Algiers stood waiting. At length I was invited to state what I would like to pay, and I suggested a suitable amount. It was then discovered that as the charge for Teneriffe, which is also situate in the Atlantic Ocean, is one franc twenty centimes (or thereabouts) a word, this figure might not be unsuitable for Madeira; on that basis the account was adjusted, and Algiers restored, after a considerable interval, to telegraphic communication with the outer world.

Although the words colonization and colonists are on everybody's lips, Algeria is not in fact a colony. It is attached to the Ministère de l'Intérieur, and is therefore technically a part of France. It is divided into three departments, each of which sends to Paris two deputies and one senator. The suffrage is " universal," but confined to citizens of French origin or naturalized. The Mohammedan natives are subjects, not citizens. A colonial air is given by the existence of a Governor-General, appointed by the President on the advice of the Ministre de l'Intérieur. The organization of local government is similar to that of France. 


\section{II-THE CORSAIR GIT}

The old town-The Arab ménage-The Penon-Barbarossa-French achievements and shortcomings - The Arab house-Christian slavery-Lord Exmouth.

"That execrable sum of all villanies."-W ESLEY.

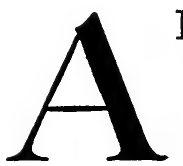

PERAMBULATION of the town of Algiers removes much of the impression of its over-modernization which is received on landing. The boulevards facing the sea and the streets immediately behind them are all new, but where the hill begins to rise steeply the traveller will pass at a step from the French city to the old Arab town. A greater contrast could not be imagined. The French love broad streets, lofty houses, big windows, open spaces, and above all straight lines. The Arab town is a labyrinth of narrow lanes, twisting and curling according to no sort of plan, in fact to all appearance so inextricably confused and so full of blind alleys that one might suppose 


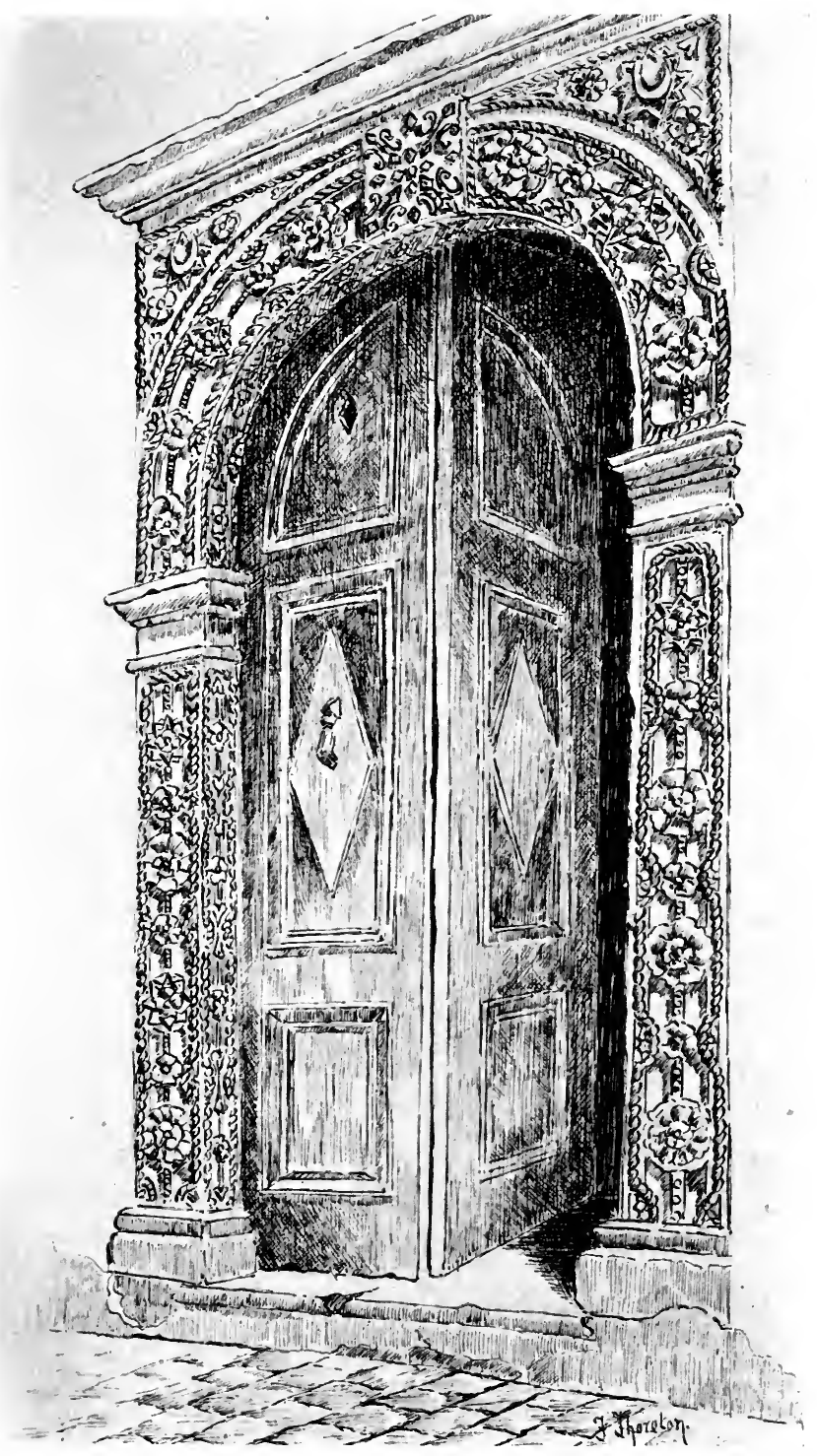

ALGIEKS: DOORWAY, RLE MFIDEA 
How 35

तो?

$\therefore$ ofut a

다.

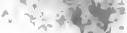

3 


\section{The Corsair City}

no living man capable of mastering their meanderings. But a stranger need be under no apprehension of being lost. He has only to keep ascending to reach the Kasbeh, the old Turkish fort at the top of the town, or descending, a course which sooner or later will bring him back to civilization. The lanes are very narrow, in many cases only just wide enough to permit a horseman to pass a foot-passenger; and as a rule the first floors of the houses, supported on diagonal cedar poles, in themselves an interesting and picturesque feature, extend over the footways, and almost meet. In many cases the road is completely vaulted. Beyond the general suggestion of ancientry there is really little in this old town to engage the attention of the stranger; a few charming marble doorways of conventional Arab design; an occasional glimpse of a colonnaded court-yard within; that is all. Writers on Algiers have strained their vocabularies in frenzied efforts to make something of this curious maze of dwellings; to produce any effect they have generally had to fall back on their imagination of what is happening behind those locked 


\section{About Algeria}

portals and those heavily barred windows; of that life of the Orient of which we know and comprehend nothing. Perhaps there is nothing very extraordinary to be known. The sombre, tyrannical master and husband, the infantile and enslaved wife,-that is our general impression of the Oriental ménage. Yet even Arab wives are not dumb animals, and all men that are born of women are born to be henpecked. Perhaps even here les paroles de l'oreiller have their force, and it may be that the stately lord sometimes meets his match.

"From a vixen wife protect us well; Save us, O God! from the pains of hell,"

says The Gulistann. The conventional sternness of the husband's control suggests a sense of his own weakness. It certainly confesses a curious diffidence as to his own charms, perhaps with reason, for, says an Arab proverb, "Quand la femme a vu l'hôte, elle ne veut plus de son mari." So even if the Western idea of Mohammedan domestic tyranny is correct ( $\mathrm{I}$ am far from believing that it is), we may at least console ourselves 


\section{The Corsair City}

with the hope that the wife sometimes has as much of her own way as is good for her.

And it would seem that women everywhere must still have chains to hug. If in Western countries the husband is no longer lord, and the priest no more director, the tyranny of the dressmaker is cheerfully, nay, eagerly, accepted. In one decade a tight cape prevents the lifting of the arms, in the next a skimpy skirt hobbles the legs; a mere man may venture to see in these disagreeable manifestations a surviving badge of ingrained servitude.

The lanes of this old town, with its squalid exteriors and possibly rich interiors, are not very clean, and to the Western eye, if not nose, they suggest insanitary conditions. But it is never safe to judge from appearances, and it may be that your brand-new botel de luxe is richer in lethal germs than this ramshackle city. I am not armed with any statistics bearing on the point. At any rate, these devious thoroughfares appear to be admirably policed, and in spite of their cutthroat appearance it is said that they are safe for passage by day or by night. 


\section{About Algeria}

If the aspiring word-painter has failed to convey any due impression of this curious labyrinth, the artist has seldom been more successful. Perhaps it passes the endurance of flesh and blood to sit and paint, where there is too little room to sit, exposed to the torments of an Arab crowd. Even the humble photographer must own defeat. The narrowness of the lanes, the height of the houses and the unwelcome attentions of the passersby try his skill beyond endurance. The casual wayfarer, content with his own impressions, has the best of it.

It appears that in Turkish times the streets of the city had no distinctive names. It may be that everyone knew where everyone else lived. The Arab, at any rate, had no address. Presumably he had no extensive correspondence. And perhaps he seldom received callers. There were certainly no public vehicles, indeed no vehicles at all. It was all, and is, a strange tangle; an incongruous medley of great houses and squalid shops, of "the grey homes of the people and the palaces of the mighty," as Mr. Lloyd George said at Mile End. With laudable intentions the 


\section{The Corsair City}

French set to work to unravel it-to give at least to every street a name, for to the European mind a street without a name is inconceivable; although we frequently see in new-fledged localities names bestowed on streets which are as yet in embryo. The official who was entrusted with the job deserves immortality in the pillory. A more hopelessly inappropriate collection of titles it would be difficult to conceive. Such aberration almost touches genius. Rue du 4 Septembre, Rue d'Amfreville, Rue du Galmier, Rue Annibal,- -such are the gems which greet our astonished eyes. And, above all, Rue Sidney Smith! What is the witty parson -or is it the admiral ?-doing in this galley? If only he had lived to know it. But so for all time, or until the next conqueror arrives, will it be.

The amateur will look in vain in Algiers for fine examples of Arab art, such as he may study at Cairo, at Granada, or at Tlemçen, in the province of Oran. The ravages of war, the stress of successive bombardments, amply account for this. The old minarets are gone; such work of the best period as may. have 


\section{About Algeria}

existed has long disappeared; what the French have spared is chiefly of the Turkish domination.

But, in truth, during the great days of Mohammedan art Algiers was not of much importance. Its site had been previously occupied by the Roman Icosium, a town of little place in history, but the seat of one of the numerous North African bishoprics of the fifth century. The Arab town was founded in the tenth century, at which time numerous monuments of the Roman period are said to have been still standing. About the year 1500, when the Moors were expelled from Spain, many settled here, and adopted the profession of pirates. It is at this time that the importance of Algiers in the history of Europe commences.

The Penon, the islet which, being connected with the shore by a mole, forms the present inner harbour of Algiers, the old harbour of the corsair fleet, is intimately connected with this period. Some good Arab work is to be seen, notably a magnificent doorway in the Bureau de la Marine, carved in white marble, or orna- 


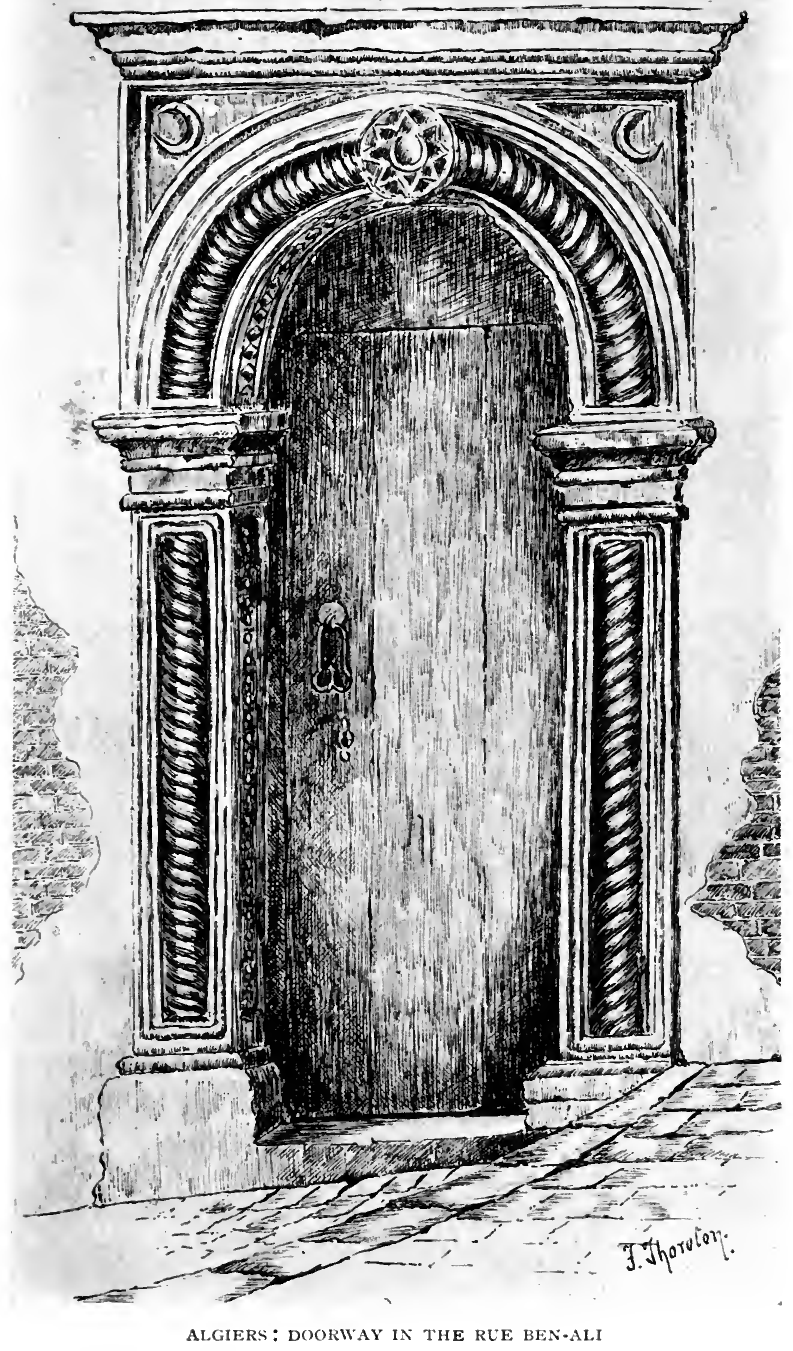





\section{The Corsair City}

mented with inscriptions and with tigers, -an infringement of the Moorish law which perhaps indicates its Persian origin. ${ }^{1}$ A small and very charming Arab house with good carving and many tiles is used as the residence of the Admiral. As I gazed deferentially at the exterior an obliging sailor invited me to enter. "This," he said, "is the grand salon of the Admiral; and this," laying his hand on the handle of a door, "the Admiral's bureau." I recalled the Oxford undergraduate who showed "his people" over his college: "That," he said, "is the Master's Lodge, and that," hurling a stone at a window, "is the Master." Perhaps my face showed some apprehension of the possible apparition of a fierce French admiral with bristling moustache hastening to repel the foreign invader, for my conductor reassured me. "M. l'Amiral est absent," he said. From a pleasant flagged terrace, with a summer-house at the further end, the Admiral may look down on the inner harbour, packed now with the French torpedoboats which have replaced the lateen-rigged vessels of its former owners.

1 See Chapter IV. 


\section{About Algeria}

The island and its mole have a strange history,-not the least astonishing episode in the annals of this astonishing city. The depredations of the Moorish pirates soon became extremely harassing to Spain; not only did they seriously interfere with Spanish commerce, but they made frequent raids on the Spanish coast, pillaging towns and carrying away their inhabitants to slavery. The evil became so pressing that at length a determined effort was made to put a stop to it. In 1509 a Spanish expedition, under Cardinal Ximenes, captured Oran and Bougie, and as a check to the pirates of Algiers occupied the island facing the town. Here they built a fort, which still exists in part, and forms the base of the lighthouse. This expedition, for which the Cardinal supplied the funds, was known as the "Crusade of Ximenes de Cisteros," and was regarded as a holy war, bestowing certain indulgences on those who took part in it.

For nearly twenty years the Spaniards held the island, commanding the roadstead and controlling the maritime proceedings of the Algerines. These found the position so irksome that their Emir, to his own un- 


\section{The Corsair City}

doing, called in the services of the celebrated pirate, Baba Aroudj, known to Christendom as Barbarossa,

"A corsair's name, linked with a thousand crimes."

The romantic story of this king of robbers supplies a curious picture of the times. At the beginning of the sixteenth century Lesbos, in Mytilene, was the head-quarters of Turkish piracy in the Eastern Mediterranean. A simple potter, or fisherman, as some say, of the island had four sons, of whom two, Baba Aroudj and Kheir-ed-Din, rose to fame. Aroudj was in particular of a soaring spirit. Marking the avenues to fortune which the staple industry of the island presented, he became "apprenticed to a pirate." An early disaster seemed like to blast his promising career; he was captured by a vessel of the Knights of Rhodes and condemned to the galleys. But such checks are to the really great only stepping-stones to higher things. Having, as was inevitable, effected his escape, he betook himself to Tunis, determined in the freer air of a new country to wipe out the memory of his early failure, and to find 


\section{About Algeria}

a fresh theatre for his energies. His professional knowledge stood him in good stead. He proposed to the Sultan of Tunis that they should enter into a partnership, in accordance with which he should conduct the active part of the business, and the Sultan receive half the profits, in consideration of his countenance and support. The Sultan, with that discernment that has so often characterized sovereigns, saw that he had to deal with a man of mark, and jumped at the proposal. A pirate station on the most approved lines was established at Djerba, where Aroudj was shortly joined by his brother, Kheir-ed-Din. The enterprise met with more than the success it deserved. Besides the ordinary dividends of the business, the brothers were able to make many very handsome presents to their partner and patron. On one occasion, it is recorded, they offered to him fifty Spanish youths holding in leash hounds and hawks of the rarest breeds, and four young ladies of noble birth, attired in splendid garments and mounted on magnificent horses. Mulai Mohammed, the Sultan, however keen a hand in purely business matters, was not the man to turn a deaf 


\section{The Corsair City}

ear to the appeal of a brother in distress. The plight of his fellow-monarch, the Emir of Algiers, moved him deeply. With a quite distinguished disinterestedness he proposed to his associates that they should abandon for a time the ordinary course of their duties and proceed to Algiers to turn the obnoxious Spaniards out of their eyrie on the island. Baba Aroudj arrived at Algiers with $5000 \mathrm{men}$, and was hailed as a deliverer. But the instincts of his trade were too strong for him. Instead of attacking the Spaniards on the Penon, he put the Emir to death, proclaimed himself King, and gave the town to pillage. Master of Algiers, with his vessels dominant at sea, he set himself to win an empire. He occupied Medea and Tlemçen, and menaced the Spanish position at Oran. This was too much, and Charles V sent thither a powerful force to check him. He retired on Tlemçen, and fell in an obscure fight at Oudjda, on the frontier of Morocco, a town of some significance in recent history, and now in the occupation of the French.

"He left a name at which the world grew pale, To point a moral and adorn a tale." 


\section{About Algeria}

His brother, Kheir-ed-Din, assumed the reins of power at Algiers. Lacking the vaulting ambition of the terrible Barbarossa, he seems to have possessed a sounder business head. His first care was to assure his position; and with this object he offered his African dominions to Selim I, Sultan of Turkey. The Turk accepted the offer, and named Kheir-ed-Din his "Captain-pasha." So arose the Turkish domination of Algeria, which lasted for three centuries, and inflicted on Europe unnumbered woes. If Europe had only known it, now was the time to cut off the serpent's head; but Europe, as usual, was busy with its own quarrels. Charles V did indeed conduct an expedition in person in 1535 , but it was half-hearted and proved abortive. No native prince arose to repel the Turkish pretensions, which were consolidated by the capture of Tunis and the occupation of Kairouan, the holy city.

Kheir-ed-Din next turned his attention to the Spanish garrison on the Penon. Having procured heavy guns, he bombarded the position for fifteen days with an incessant fire. The garrison of 150 men made a heroic 


\section{The Corsair City}

resistance, but when all save twenty-five were killed, the island was captured and the survivors put to death.

The brave commander, Martin Vargas, was offered the alternative of embracing Mohammedanism and a Mohammedan wife or execution. $\mathrm{He}$ chose the latter, and was beaten to death with sticks, his body was dragged through the streets, cut into pieces, and thrown into the sea. So did the corsair treat a gallant foe.

It was then that Kheir-ed-Din conceived the project of uniting the island and the city, with the double object of preventing any repetition of the Spanish occupation and of providing a harbour for his fleet. Thirty thousand Christian slaves supplied him with labour, and materials lay near to hand. The ruins of the old Roman city of Rusgania strewed the shore at Cape Matifou; and countless blocks of Roman hewn stone and marble lie buried beneath the floor of the mole. The work, a very big work for the period, was finished in three years, and henceforth for nearly three centuries the corsair fleets lay within, safe from the storms of the Mediterranean and the attacks of their enemies. 


\section{About Algeria}

Kheir-ed-Din's son mounted batteries on the Penon, and built the lighthouse tower in 1544 . It is of octagonal shape, nearly I 20 feet high, and visible for a distance of fifteen miles. A band of gleaming tiles below the summit happily relieves the monotony of its elevation.

The present great harbour, covering 222 acres, was commenced by the French in 1836 . It was formed by continuing the line of Kheired-Din's mole to the south-east, and building another of irregular form from a point to the south of the city. In these works blocks of concrete were used for the first time in such operations, -an experiment which has had important results. In the making of this great harbour, as in so many other constructive matters, the French have risen to the level of their opportunities. Their genius in such large matters is unquestioned; and if anyone doubts their pre-eminence in minor arts, let him compare their coinage and their postage stamps with those of any other nation.

The French have done many great things; one thing they have omitted,- to provide an adequate service of passenger steamers 


\section{The Corsair City}

between France and North Africa. They have generally fallen behind in the race of maritime improvement in recent years; but the insufficiency of this particular service may be due to the fact that trade between Marseilles and Algeria is held to be French coasting trade, and therefore reserved to vessels sailing under the French flag. The stimulus of foreign competition is absent. But nothing can prevent the indirect competition of the superior steamers of the North German Lloyd to Genoa, which are securing much of the tourist traffic. This company is gradually establishing a network of steamer lines in the Mediterranean. And a service of fast steamers covering the voyage between Barcelona and Algiers in twelve hours is now mooted. This may prove a further nail in the coffin of the Marseilles route. But the French have it in their hands to retain the trade by running adequate steamers properly equipped.

In spite of the heavy hand of the destroyer a few fine houses of the Turkish domination survive, and some are put to public uses and are accessible to the stranger. They exhibit a usual characteristic of the Eastern house; 


\section{About Algeria}

they are insignificant, sometimes even squalid without, but like the princess they are all glorious within. Christendom builds its houses for the public eye. This is not entirely altruistic; not wholly due to a desire to please the neighbours; a man's credit and importance (even, it is said, the amount of his doctor's bill) bear some relation in the opinion of his world to the outward appearance of the house in which he lives. And in the northern view, at any rate, a man's house is a consideration prior to his equipage, his retinue, and his personal adornment. And some value attaches to what is called "a good address." Wherefore our note-paper headings often contain a suggestio falsi; and Glenalmond Villa or The Elms strive to conceal the banality of a mere terrace.

All this is unmeaning to the Mussulman. $\mathrm{He}$ fulfils Bacon's dictum that "houses are built to live in, not to look upon, wherefore let use be preferred before uniformity." A bare wall with narrow and barred windows facing a mean alley;-such is his house's exterior. It seems rather to desire to escape than to court observation. It has more the 


\section{The Corsaiv City}

air of a fortress than of a dwelling. The doorways are an exception to the prevailing plainness. They exhibit a great variety of detail, but mainly follow a Roman or Byzantine scheme, of a round arch supported on columns, the whole copiously decorated. The doors themselves are generally of simple woodwork, often heavily studded with iron, and sometimes retaining their fine old handles and knockers. To the wanderer in the Arab town they offer a never-failing source of interest and study. The elaboration of the doorway when all else that is external is plain would seem to be thoroughly congruous with Oriental taste and tradition. The door of the house and the gate of the city stand for much in private and public life, for the line that divides the intimate and the stranger, the friend and the foe. Our fathers had some sense of the dignity of the door, a sense which in our careless acceptance of decadent conventions we have almost lost. We may strive to recover it in contemplating these Arab portals. The charming drawings of Mr. Thoroton, here reproduced, accurately represent their general scheme and the variety of their E 


\section{About Algeria}

ornament. A common decorative feature appears to be based on the artichoke; the precision of its symmetry doubtless appeals strongly to Mohammedan prejudices.

When you have passed the portal the very contrast of the squalor without heightens the effect of the splendour and refinement within. The usual type of house is one which the Arabs owe to the Romans, or both to an earlier source. The doorway opens on to a long vestibule, with a row of marble seats on either side, divided at regular intervals by columns, often twisted and generally suggesting the Ionic order. From this you pass into the main dwelling, a square marble court open, or partially open, to the sky, round which are grouped the chief rooms. Marble columns support the gallery of the first floor, the walls are a blaze of tiles, a fine dark balustrade of open woodwork surrounds the gallery; and in the centre of the court-yard perhaps the pleasant plash of a fountain emphasises the pervading peace. It is all very splendid, and yet most dignified. Such a beautiful house is used as the Bibliothèque Municipale, a library with 35,000 


\section{The Corsair City}

volumes, many Arabian and Persian MSS., and an up-to-date card catalogue. Another is the residence of the Archbishop. This is said to be a fragment of the ancient palace of the Deys. It is a pleasant touch of humour which lodges the Archbishop in the last remnant of the harem. To these may be added the Governor's Winter Palace, with a modern front and rich interior decorations; and a few other houses occupied by officials, and not open to inspection without an introduction.

A mere civilian must bow before the requirements of the military authorities, but he may be permitted to regret that they should have seen fit to turn the Kasbeh, the ancient fortress of the Deys, into a barrack. As may naturally be expected, the decorations and many of the original features have disappeared; marble columns have been replaced by wooden posts, tiles have been picked off,-and the Dey's pavilion has been repainted! Worse than all, a public road has been driven right through the centre of the old compact mass of buildings surrounded by their embattled wall. The visitor will turn away with 


\section{About Algeria}

disgust from this reckless spoliation, which will some day no doubt be bitterly regretted.

Of the mosques of Algiers, that of Sidi Abd er Rahman, adjoining the tomb of the saint, is the most picturesque. The great mosque of Djama el Kebir has a very handsome exterior, notably a magnificent colonnade fronting the Rue de la Marine. The entrance is pleasing, but the interior rather bare. The mosque in the Place du Gouvernement, known as the New Mosque, was built in 1660 to the designs of a Christian slave, and is in the form of a Greek cross. The Catholic Cathedral was formerly a mosque, and is now an eclectic monstrosity.

The interest which Algiers has for the traveller is closely bound up with the hideous story of the Christian captives. Our literature, especially of the seventeenth century, is full of allusion to their miserable condition. Their numbers were prodigious. In 1646 it was reckoned that there were not less than 20,000 such slaves. During our Civil War the Channel was full of Algerine pirates, and their operations extended to the North Sea. The Long Parliament passed an Act "whereby they did 


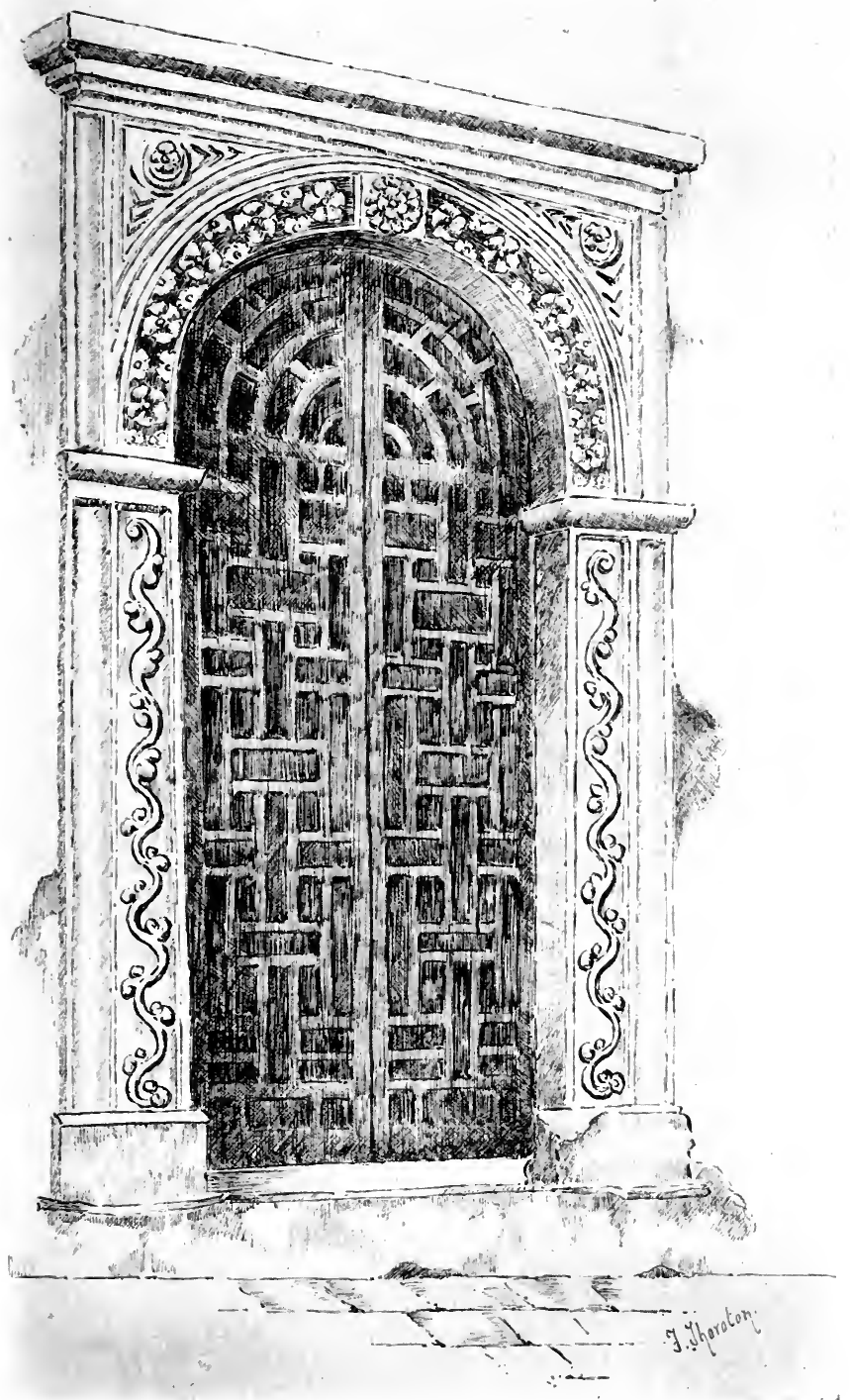

ALGIERS: ENTRANCE-DOOR OF THE MOSQUE, RUE DE LA MARINE 
4 is 


\section{The Corsair City}

manifest unto the world their resolution of undertaking that Christian work of the Redemption of the Captives from the cruel thraldom that they lay under," and established a tax on merchants' goods, called "Algier duty," to provide funds for the purpose. Many distinguished men were at one time or another slaves in Barbary. Cervantes was in captivity for five years, and has related some of his miseries in the story of "The Captive" in "Don Quixote." He who went to sea in those days had to face the chance of " being taken by the insolent foe and sold to slavery." It will be recalled that before he set forth on his immortal voyage Robinson Crusoe was captured by a Sallee-rover, and worked as a slave. Samuel Pepys records (February 8th, I660-I) a conversation on the subject: "At noon to the Exchange to meet Mr. Warren the timber merchant, but could not meet with him. Here I met with many sea commanders, and among others Captain Cuttle, and Curtis and Mootham, and I went to the Fleece Tavern to drink; and there we spent till four o'clock, telling stories of Algiers, and the manner of the life 


\section{About Algeria}

of slaves there. And truly Captain Mootham and Mr. Dawes (who have been both slaves there) did make me fully acquainted with their condition there : as, how they eat nothing but bread and water. At their redemption they pay so much for the water they drink at the public fountaynes, during their being slaves. How they are beat upon the soles of their feet and bellies at the liberty of their padron. How they are all, at night, called into their master's Bagnard [prison]; and there they lie. How the poorest men do use their slaves best. How some rogues do live well, if they do invent to bring their masters in so much a week by their industry or theft." Other accounts give far more harrowing details of the sufferings of the slaves and of the tortures they endured.

When a prize was brought in, the crew and the passengers were forced by torture, generally the bastinado, to declare their quality and condition. The Dey selected one in eight for himself, generally preferring skilled workmen. The remainder were sold by auction for the benefit of the owners and crews of the pirate vessels. The European 


\section{The Corsair City}

Powers maintained consuls at Algiers, and through them, and other agencies, those of the captives whose friends could find the ransom demanded, were, after much delay, redeemed.

That such an iniquity was more or less tolerated for centuries is one of the curiosities of history. It can only be explained by the fact that European nations found it a convenient scourge for their enemies. France and England especially were continually intriguing to make infamous treaties with the Dey to the benefit of each against the other. All nations, including the United States of America, after they obtained their independence in 1783 , paid tribute to the Dey in one form or another to secure the exemption of their vessels from capture; but the Algerines never respected any treaty when they could violate it with advantage or probable impunity.

The close of the Napoleonic wars gave England not only undisputed command of the sea, but leisure to deal with the open sore of Algerian piracy. She was not slow to use it. At the beginning of 1816 Lord Exmouth 


\section{About Algeria}

was ordered to visit the Barbary States and obtain the release of such slaves as were British subjects-chiefly Ionians-or subjects of Great Britain's allies. At Algiers the Dey readily released the Ionians, and also the Neapolitans and Sardinians, on payment of a ransom. Lord Exmouth proceeded to Tunis and Tripoli, and concluded treaties with the Beys, who agreed to abolish the institution of Christian slavery altogether. He then returned to Algiers and endeavoured to get the Dey to make a similar treaty. The Dey declined to accede, but finally consented to treat at London and Constantinople. Lord Exmouth took a high hand; he told the Dey that he evidently had little idea of the power of a British man-of-war, and that he would engage, if hostilities became necessary, to blow the place to pieces with five line-of-battle ships. Shortly after he had sailed for England matters were brought to a climax by an attack by Turks and Arabs on a large number of coral-fishermen, sailing under French and English colours, who had landed at Bona on Ascension Day. About two hundred were massacred in a church and 


\section{The Corsair City}

hundreds more wounded. The British consul was killed, the houses of Christians pillaged, and the British flag trampled under foot. The British Government considered that the cup was now full, and that strong measures must be taken against these barbarians. On Lord Exmouth's arrival a fresh fleet was fitted out. He was offered any force he required, but he determined to rely on the five battleships he had mentioned to the Dey. To these were added five frigates and some smaller vessels. At Gibraltar he found a Dutch squadron of five frigates and a corvette under Admiral van Capellan, who asked and obtained leave to co-operate.

After some vexatious delays Exmouth arrived off Algiers on August 26th, 1816. His despatch, dated August 28th, is very interesting reading. He had previously sent on the Prometheus, to endeavour to bring away the British consul, Captain Dashwood. A landing party brought off his wife and daughter, disguised in midshipmen's uniforms. The surgeon was following with the consul's infant child concealed in a basket. As he was entering a boat the child, unfortunately, cried, with 


\section{About Algeria}

the result that the surgeon, three midshipmen, and others, in all eighteen persons, were seized and confined as slaves in the usual dungeons. "The child was sent off next morning by the Dey, and as a solitary instance of his humanity it ought to be recorded by me," says his lordship. Captain Dashwood was closely confined in irons.

The Prometheus brought word that energetic measures of defence had been taken; that additional works had been thrown up, and a large army assembled. The whole Algerine fleet was collected within the mole. On the morning of the 27th the fleet was lying in sight of the city becalmed, and Exmouth sent ashore a flag of truce with the demands he was instructed to make. Receiving no answer, and the day breeze landwards having sprung up, he moved his fleet in towards the mole, the Queen Cbarlotte, the flagship, leading. The shore batteries opened the engagement with a tremendous fire, whereupon the leading ship commenced action. Before nightfall the enemy's fleet was completely destroyed, his batteries abandoned, and half the town in ruins. At midnight the ships and parts of the 


\section{The Corsair City}

town were still burning. Thus did Lord Exmouth demonstrate to the Dey the power of five English ships of the line. The battle was of quite an unprecedented nature; it was a new departure to bring a fleet up close under the guns of formidable batteries. The fleet had poured 50,000 shot, weighing over 500 tons of iron, into the town, and used 118 tons of powder. A little touch illustrates the close quarters of the combatants. A vast crowd of Arabs was collected on the shore, and before he opened fire Lord Exmouth called out and waved to them to depart. The warning had no effect, and thousands were killed.

The English losses were considerable, I23 men killed and 690 wounded. The Dutch had 13 killed and, 52 wounded. Lord Exmouth himself was struck three times, but escaped unhurt. It was pointed out at the time that, in proportion to the number of men in the English ships engaged, the casualties were far higher than in any of Nelson's victories.

The Dey must have passed an uncomfortable night, and morning found him in a very humble mood. He agreed to all the English 


\section{About Algeria}

demands ; these were, the abolition of Christian slavery for ever, and an undertaking to treat prisoners of war according to the usage of civilized nations; the immediate delivery of all slaves; the repayment of the ransom of the Neapolitan and Sardinian captives; an apology and reparation to the English consul. Having accepted these comprehensive and ignominious terms, not as regards the apology to the consul with a very good grace, the Dey consoled himself by beheading his prime minister.

It has been given to another nation to break down for good and all the Turkish tyranny, and to restore these fair lands to Europe and civilization, but we may congratulate ourselves that the gallantry of our own navy dealt the first serious blow, and exposed the hollowness of the game of bluff which the corsairs of Algiers had played against Christendom for centuries. Yet nothing can quench our wonder that the hand was held up so long, even into the lifetime of men still living and vigorous. 


\section{$I I I-N E W$ ROADS AND OLD CITIES}

Rome's successors-The Road and its influence-Algerian highwaysThe motor-car and modern travel-An aqueduct-Cherchel-

Cleopatra's daughter - Tipasa - The French as Colonists Viticulture.

"Among the ruins of old Rome, the grandeur of the Commonwealth shews itself chiefly in temples, highways, aqueducts, walls and bridges."-ADdison.

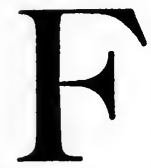

ROM many points of view the modern French may be regarded as representing most fully among the peoples of Europe the Romans of the Empire. The sturdy physique and unrivalled endurance, the unsurpassed gallantry and devotion to duty of their soldiers, recall the qualities of the legions. Their absorbing pride in and love for their native land is an echo of the tremendous sentiment of Roman citizenship. The logical coherence of their legal system is frankly based on the jurisprudence of Rome. Their faculty for producing the most perfect 


\section{About Algeria}

work in the more refined forms of engineering and the manufacture of delicate tools and machines is a natural development of Roman thoroughness in constructive matters. And like the Romans they are the slaves of convention. Everything Roman was according to a settled plan. The empire was a vast aggregation of cities which aspired to be little Romes. From the borders of Scotland to the fringe of the Sahara, from Portugal to Asia Minor, cities were raised more or less, as circumstances permitted, fulfilling the conventional design; conventional not only in town-planning, and in the scheme of public buildings, but in the architecture of private houses and the most minute details of decoration. We grow weary in the museums of today of the repetition of the same motives in sculpture, in mosaic and in bronze-work. The only variety is in the quality of the execution. So, too, must a French town, a French house, a Frenchman's manners and a Frenchwoman's clothes be in accordance with a sealed pattern deposited in the temple of the great goddess Comme-il-faut. The French are the most law-abiding of nations, but their laws are 


\section{New Roads and Old Cities}

les convenances. The occasional licence exhibited in their art and literature and morals is but the effort of a few eccentric individuals, not always of unmixed French breeding, to break through the trammels in which the mass of the race is bound.

In this country the French have set themselves from the first to carry on the Roman tradition in the making of roads. In a land which for twelve centuries has known little but destruction and decay they have built, as the Romans built before them, solid, uncompromising, inevitable highways, roads on which armies may march secure of ambush, and almost regardless of the hostility of natural forces;-roads which create not only peace, but prosperity in their course. The road is one of the most effective as it is one of the most permanent works of man. In England quite a large proportion of our main roads still follows the lines laid down by the Romans. We are ourselves rather road-menders than road-makers. Our genius finds its work in other directions. We have been in South Africa far longer than the French in North Africa, and what have we to show 


\section{About Algeria}

there at all comparable with the Algerian roads?

In one of the most notable books of our generation, Mr. Hilaire Belloc has set before us the uses, the influence, the interest, and the fascination of the road. In the course of an exploration of one of those ancient highways which we English have permitted to fall into decay and in part to disappear, he has taken occasion to impress on us the part which the road has played in the spread of civilizing influences. Algeria-roadless and anarchical for centuries, orderly and webbed with roads to-day-may add point to his argument. "More than rivers and more than mountain chains, roads have moulded the political groupings of men. The Alps with a mule-track across them are less of a barrier than fifteen miles of forest or rough land separating one from that track. Religions, which are the principal formers of mankind, have followed the roads only, leaping from city to city and leaving the 'Pagani,' in the villages off the road, to a later influence. Consider the series, Jerusalem, Antioch, Ephesus, Athens and the Appian Way; 


\section{New Roads and Old Cities}

Rome, all the tradition of the Ligurian Coast, Marseilles and Lyons. I have read in some man's book that the last link of that chain was the river Rhone; but this man can never have tried to pull a boat upon the Rhone upstream. It was the Road that laid the train. The Mass reached Lyons before, perhaps, the last disciple of the apostles was dead; in the Forez, just above, four hundred years later, there were most probably offerings at night to the pagan gods of those sombre and neglected hills. And with religions all that is built on them: letters, customs, community of language and idea, have followed the Road, because humanity, which is the matter of religion, must also follow the road it has made. Architecture follows it, commerce of course, all information; it is even so with the poor thin philosophies, each in its little day drifts, for choice, down a road." 1

The making of the Algerian highways has been no light matter. They have frequently demanded much engineering skill. Their repair is a difficult and expensive business, the heavy winter rains and the fierce summer

2 "The Old Road," 1904, p. 5.

F

$8 \mathrm{I}$ 


\section{About Algeria}

sun have a rapidly disintegrating effect on the friable materials available. Algeria is not only an exceedingly mountainous country, but its physical conditions are very peculiar, and, except by those who have explored them, not as a rule very fully understood. The common idea of a fertile belt, more or less hilly and of varying width, between the sea on the north and the Sahara on the south, is imperfect and incorrect. As a very rough generalization, subject to innumerable variations of mountain and valley and plain, Algeria may be said to consist of two parallel ranges of mountains running north-east and south-west. The northern range slopes very gradually to the sea, often in a series of plains, providing with its copious rainfall that fertile tract known as the Tell, once the granary of Rome, and now again developing a great export trade. The Tell itself contains numerous ranges of lesser hills, called Sahels. The southern range faces the desert, in the east, in the great rocky mass of the Aures, with steep cliffs; in the west less abruptly. Between the two ranges is contained a lofty plateau, of convex form, in the main barren 


\section{New Roads and Old Cities}

and sandy, but covered here and there with scrub. In many of its features it imitates the true desert. It has its shallow depressions filled with brackish water; and its inhabitants dwell in rare oases where fresh water occurs. The mountains attain no great elevation, their summits seldom exceeding 6000 feet. This is a pity. A lofty range treasuring copious stores of eternal snow would perhaps have made of the high plateau a veritable garden; and its influence would have been felt far southwards into the Sahara. The direction of the mountain lines causes the Tell, the land of tilth and colonization, to be wide at the western end of the Colony, in the province of Oran, and narrow at the eastern end, in the province of Constantine.

Where the desert breaks in waves of shifting sand against the southern range, where the streams run southwards and lose themselves, there and not on the seaboard of France and Spain would seem to lie the destined boundaries of Europe; this the proper limit of European enterprises. The sea is to-day less than ever a barrier, dissociabilis; it is rather a link. The Mediterranean may lash 


\section{About Algeria}

itself in rage, but its rage is impotent to check the progress of the great steamers. The southern frontier of the Roman Empire is once more the southern frontier of Europe. The burning sands of the great Sahara are the true divide. Yet French enterprise is loth to admit this. The indomitable spirit of adventure, of adventure however profitless,-the spirit which led their Crusaders to the Holy Land, the army of Napoleon to Moscow, and Marchand on his interminable desert march to anticipate Kitchener at Fashoda,- this spirit is still at work. Further into the Sahara the outposts are continually being pushed; a railway is projected to Timbuctoo, now a journey of three months for caravans; and the connection of the French Colonies in North and West Africa has long been mooted. We may admire this spirit and its manifestation, but in all deference may ask, Is it business?

At the time of the French invasion, eighty years ago, there was not a single road in the interior of Algeria. The Roman roads had disappeared. The Arab paths only permitted the passage of horsemen, and wheeled vehicles 


\section{New Roads and Old Cities}

were unknown. In the Tell transport was by mules, in the south by caravans. The army no sooner landed than it began to lay out roads, and for some time afterwards their construction was in the hands of the military engineers. They are now in the care of a special department. The system which has been evolved consists of a great artery running east and west from the frontier of Tunis to the frontier of Morocco, united by branch roads to the chief ports on the coast, and sending forth great feelers southward to the Sahara. These are the great national trunk roads constructed and maintained by the state for strategic purposes, and they have a total length of about 2500 miles. Besides these, the state has assisted in the making of a great number of roads partly strategic, but for the most part designed to open up new regions to colonization. These, with the ordinary country roads, make up a total of nearly I0,000 miles.

It would almost seem that in the design of the great highways running east and west, and north to sea, and south to the desert, the French had some prescience of the invention of the motor-car. The roads are, 


\section{About Algeria}

in fact, most admirably adapted to its use, often from their open character and long straight stretches (a part, no doubt, of their military intention), at almost any possible speed. And their surface is commonly excellent. Remote places formerly only to be reached by painful journeys in jolting diligences are now within easy reach. And although the automobile is still the luxury of the few, it may not be long before popular "omnibus" vehicles will extend its advantages to the many. The railway train is becoming the inferior beast of burden,-crawling wearily along at its African pace of fifteen or twenty miles an hour; while the sprightly motor-car flies past, perhaps at a speed of fifty. It is true that Article I4 of the Règlements for Algeria provides that "en aucun cas, la vitesse n'excédera celle de 30 kilomètres à l'heure en rase campagne et celle de 20 kilomètres à l'heure dans les agglomérations," but there seems to be no disposition to enforce this; and there are no police traps, and no A.A. scouts. The really important provision is, "le conducteur de l'automobile devra rester constamment maître de sa vitesse." 


\section{New Roads and Old Cities}

We may take it therefore that travel in Algeria is entering on a new phase; that this most beautiful and interesting country has at a blow become accessible to the traveller who has neither time nor inclination for primitive methods of journeying; and that in the matter of country hotels French enterprise will surely rise-it is already rising-to the new opportunities. There are motorists and motorists; to one class the car itself is allimportant, the country traversed a minor matter, the surface of the road on which "she" is to display her powers being the first consideration. Such enthusiasts will bring their own cars, and will perhaps not regret doing so. But there are also persons of grovelling mind, who cannot rise to any enthusiasm over carburetters and petrol consumption, who, in fact, regard the motor-car as merely a very agreeable means to a very desirable end. Such lowly souls will perhaps be satisfied with hiring a car in Algiers. They will find no difficulty in selecting an adequate vehicle at a reasonable rate; no Black Care will sit behind them,-if a breakdown occurs they have only to study the 


\section{About Algeria}

scenery until it is repaired; and they will have the advantage of a chauffeur who knows the country, and will not forget the rule of the road at a critical moment. He may have other qualities; -ours was a sportsman, and would produce a gun and shoot thrushes for our dinner while we photographed Roman temples. Our murmured pity at their death missed its mark; he regarded them simply as very good-to eat. And so they are.

Before he sets forth on more ambitious journeys, the master, temporary or permanent, of a motor-car may make several interesting expeditions in the neighbourhood of Algiers. The guide-book will suggest his objective, the excellent maps of the "Voies de Communication" will point out the way. If his tastes run in the direction of visiting historic sites, he may spend a very interesting day in motoring to Cherchel, the ancient Julia Cæsarea, situate on the coast about seventy miles west of Algiers. He has a choice of routes; he may proceed inland to Blidah, and thence to Marengo, and so to Cherchel, and return by the coast road, or vice versa. We chose a middle course. We followed the Blidah road 


\section{New Roads and Old Cities}

as far as Boufarik and then turned westwards by country roads to Marengo. With occasional interludes of roughness, especially where the marshy nature of the country renders their maintenance difficult, these roads are very good. They traverse a well-cultivated district of the great plain between the coast-hills and the Lesser Atlas, of which the snowy summits are brilliant in the morning sun. On a hill to our right we catch a glimpse of the curious Tombeau de la Chrétienne, so called;-in all probability the mausoleum of Juba II and Selene his wife, the founders of Cæsarea. It is placed on the summit of a hill 756 feet above the sea, and is a circular building of about I 30 feet in height. Like most Roman buildings it has been used as a quarry by subsequent peoples; perhaps the solitary capital of a column which I noticed on a farm gateway came from this source.

Between Boufarik and Marengo the country is fairly well cultivated; substantial farmhouses, surmounted by groves of eucalyptus trees, stand amid great fields of vine and corn. It is difficult to realize that, in spite of its long history, this is essentially a new 


\section{About Algeria}

country, far newer than the Colonies of South Africa, newer than a good deal of Australia. At Marengo we join the main road from Blidah to Cherchel and descend rapidly by the side of the newly-constructed railway. From a contemplation of the enterprise of modern France, we are taken back at a bound to the works of ancient Rome by the appearance on a hill to the left of a portion of the aqueduct of Cæsarea. At this point it spans a lateral valley in a triple series of arches, rendered perhaps more impressive by a breakage in the middle. Leaving the car we scramble up by the side of a stream and reach the great watercourse itself. Passing beneath its arches we ascend the valley a little, and turn to look down on its immense proportions. Amid the rough mountain scrub we have passed from all evidence of modern cultivation, and are alone with this mighty fragment of the past. It is difficult to find a reason for the feeling, but few of Rome's monuments impart a fuller sense of her magnificence than the aqueducts which survive at so many different points of her Empire. They are a symbol perhaps of her relentless power over nature 


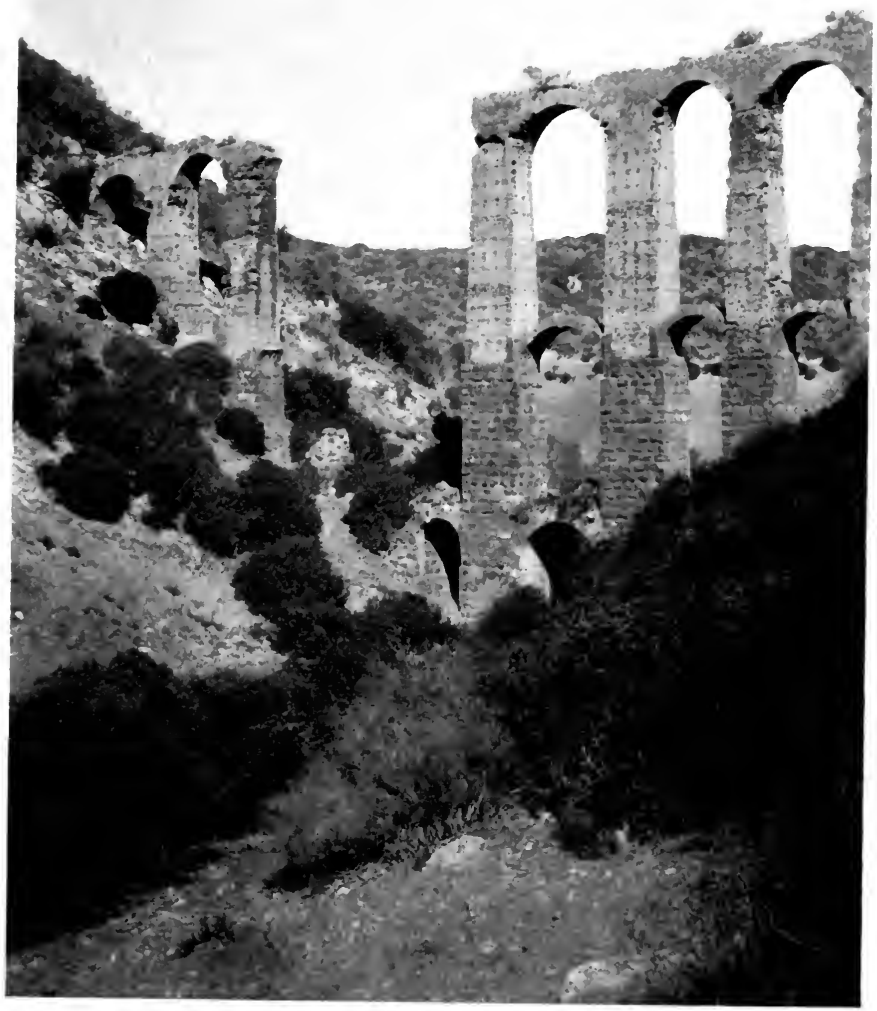

CHERCHEL : THE AOUEDUCT 
$$
-2 e^{2}+g^{2}=x^{2}
$$ 


\section{New Roads and Old Cities}

and man, of her determination to have what she wanted at all cost. Sometimes, as in the Campagna, it is the long lines of interminable arches which impress us; here it is rather their soaring height. Many modern peoples would have carried the open watercourse by a circuitous cutting on the hill-side round the head of the little valley; such a proceeding was alien to the directness of Rome.

"See distant mountains leave their valleys dry, And o'er the proud arcade their tribute pour, To lave imperial Rome."

The city to whose fountains and baths the aqueduct brought copious streams of fresh water from the hills has disappeared. A squalid little port fills some of its site, and entombs its marbles, but the aqueduct, situate too far from the habitations of subsequent man to serve his purpose as a quarry, and too threatening with its mass to encourage any hasty attempt at demolition, has survived.

A mile or two lower down are a few arches of a branch of the same aqueduct; perhaps more picturesque in their greater ruin, but 


\section{About Algeria}

less impressive in their situation and height. All around as we enter Cherchel are evidences of its ancient glory. The fashioning of the ground, the great squared stones which are built into the walls, the marble columns lying about in the town square, and the huge masses of shapeless brickwork on the shore prepare us for the collection of statues and other objects gathered together in a well-arranged museum.

The city of Cæsarea, renowned for its magnificence in the splendid Roman world of the first century, rose under the hand of a woman, as Carthage under Dido's. To the loves of Antony and Cleopatra was born the Princess Selene. In her veins flowed the blood of the Ptolemies,-perhaps of the Pharaohs, - and of the paramount family of Rome. Truly, to adapt the language of the turf, was she bred for building. Possibly with the idea of providing for this inconvenient young lady at a safe distance from Rome, Augustus mated her to Juba, a descendant of that Masinissa, King of Numidia, who had been the staunch ally of the Romans in their long struggle with Hannibal. Juba, 


\section{New Roads and Old Cities}

educated at Rome, had developed literary tastes. He is lauded by Pliny for his erudition, and we learn from Plutarch that he merited a place among "Royal and Noble Authors." Save perhaps for the dark blood of his ancestry, he was a fitting match for Cleopatra's daughter, especially as he was restored to the Numidian throne of his family, with all the power of Rome behind him. Retiring to the ancient Phœnician town of Iol, the Royal pair set to work to raise a noble city, which perhaps with a punning reference to its former name they called Julia Cæsarea; and to gather around them a circle representing the best culture of the time. Marble colonnades and porticoes, baths and theatres and temples sprang into being on the fair curve of the bay beneath the wooded hills. Great libraries enshrined the literary labours of the monarch and the learning of the age. The scholars of Greece found a comfortable and inspiring home at the court of the pedantic king, and the existence of a hundred thousand citizens attested the material wealth of the new city. Juba and Selene lived here in peace to old age. The king died in A.D. 19, 


\section{About Algeria}

and was succeeded by his son Ptolemy, who inherited none of his father's good qualities. A debauched tyrant, he plunged his kingdom into anarchy and was summoned to Rome. He was received with every mark of honour, but was put to death by Caligula, because, as it was said, the splendour of his attire unduly excited the attention of the populace.

Ptolemy's sister Drusilla was the wife of that Felix, Governor of Judæa, before whom Paul reasoned of righteousness, temperance and judgment to come, so that Felix trembled, and answered, "Go thy way for this time; when I have a convenient season I will call for thee." Drusilla is described in the Acts of the Apostles as a Jewess, which she was not, by birth at any rate.

It is sad to learn that as late as 1840 much of the Roman city was still to be seen. The theatre, now marked by a mere depression in the ground, was almost perfect. Here we have a genuine grievance against the French conquest; but 1840 was in the dark ages. So Cæsarea has passed; the Vandals, the Arabs, the earthquakes, and the French have all done their worst : and between them they 


\section{New Roads and Old Cities}

have made an end of it. Perhaps even a systematic excavation would not yield us much of value. The statues to be seen in the museum are for the most part copies of statues already found at Rome, and suggest that there was little originality in the artists employed by Juba and Selene. But nothing can impair the beauty of the site, and not even the presence of a banal Franco-Arab town can forbid us to dream of a white marble city beneath a deep blue sky and facing a purple sea.

So we turn homewards. For a while we follow the Marengo road by which we came; pass the great aqueduct again; but shortly turn to the left to reach Tipasa and the seaside road to Algiers. As we approach the coast traces of the Roman past are everywhere;-on every mound great shaped stones, " the splendid wrecks of former pride," lie in confusion, and here and there a portico suggests the existence of a suburban villa,

"While oft some temple's mouldering tops between With memorable grandeur mark the scene." 


\section{About Algeria}

When we reach Tipasa itself the great stones lie in heaps, in most admired disorder. The ruins in their extent seem to indicate the existence of a greater town than the historians admit Tipasa to have been. It is said to have been founded by Claudius as a colony of veterans, and to have contained 20,000 inhabitants. It is rich in memories of the great Arian controversy which played so important a part in the history of North Africa after the triumph of Christianity. In A.D. 484 the Vandal king, Huneric, imposed an Arian bishop on the Catholic inhabitants. A great part fled to Spain; those who remained and refused to accept the heresy had their right arms lopped off and their tongues cut out. It would seem that different branches of Christendom have often been inclined to treat their erring brethren with more severity than they meted out to the unregenerate heathen. Perhaps the heathen has ever been a more likely convert.

The situation of Tipasa belies the opinion that the ancients had no eye for natural scenery. It stood on a fair promontory sheltering from the east a little cove which 


\section{New Roads and Old Cities}

is protected from the west by the great mountain mass of Djebel-Chénoua, which lies between Tipasa and Cherchel. The country around is singularly picturesque, and the tout ensemble very beautiful, even for this beautiful coast.

Thence we start for a run of fifty or sixty miles by the seaside road to Algiers, a road which has been splendidly engineered, and is kept for the most part in a condition beyond praise. In front of us stretches the coast-line past the Bay of Algiers to Cap Matifou; on our right are the wooded hills of the Sahel. Here and there the land between the road and the sea is laid out in gardens formed in small rectangular plots divided by hedges of a tall reed to break the force of the wind. Even so the Dutch nurserymen erect screens to protect their tulips on the wind-swept lowlands of Holland. In these enclosures we particularly note frequent plantations of the tall "silver" banana. And so in due time we reach Algiers, conscious of a well-spent day.

Travel gives the death-blow to many illusions. If there is one tenet to which British self-complacency has clung with more desperate 


\section{About Algeria}

energy than another, it is that our people are the only successful colonists. We are ready to admit that the German has hardly had a fair chance. He is relegated for the present to desert tropical lands which failed in the past to tempt even Portugal. That France owns colonies of a different class we have been dimly aware, but the oracles of the club and of the Press have consistently pictured to us the French colonist as a miserable being who passes his time sipping absinthe in a café, and longing for his return to la belle France. Possibly in the purlieus of Algiers such a being might be discovered; at any rate, he is certainly not more in evidence than the "remittance men" and bar-loafers are in our own colonies. And a motor drive for twenty or thirty miles through the rich plain which encircles Algiers will send our long-cherished belief a-packing to the limbo of dead British prejudices. We have recently discovered that the home-staying French, at any rate, know something about practical gardening, and the raising of vegetable crops for market; that their scientific methods and untiring energy combine to get more out of the ground than 


\section{New Roads and Old Cities}

we do; and we have even been led to pocket our pride and to import certain practical French gardeners, at a fancy wage, to show us how the thing is done. In this we are only following the example of our ancestors, who acquired most of their arts and crafts from French and Flemish refugees. Yet it was quite a shock when one of these new-comers, looking round him at the fair fields of the home farm on a great estate in a southern county, ingenuously remarked, "But why is not this country cultivated ?"

Of this great plain between the sea and the mountains no such question could be asked. Some corn is raised, and some vegetables, such as artichokes, but most of it is devoted to the culture of the vine. It is all in the highest state of cultivation, and not an inch is wasted. The vines are planted in open fields, with the precision of the hops of Kent. Now is the time of pruning, and they are all being cut back to within a foot or so of the ground. To an eye accustomed to the hillside and rocky vineyards of the Rhine, of Italy, or of Madeira, to the vines which in Southern Europe throw themselves in reckless 


\section{About Algeria}

abandon over trellises and wayside trees, these flat fields, which suggest turnips or beet, have a very unromantic appearance. But it is easy to see that the cultivation is conducted on the most scientific and business-like lines.

It was our privilege to be invited to visit a French gentleman and his family at their residence about twenty miles from Algiers. Our host has purchased a large tract of land, the whole of which he has turned into a great vineyard. $\mathrm{He}$ has built a pleasant country house, and filled it with treasures of Arab art, and the trophies of travel in other lands. $\mathrm{He}$ has planted a garden of palms and subtropical shrubs-a garden not kept up to the standard of English trimness, but rich in shade, and pleasantly suggestive of a jungle. Not only are his vines planted and pruned with mathematical precision, but all his machinery for the extraction and treatment of the grape juice is of the latest and most practical character. A long building lined with huge vats gives an idea of the greatness of his undertaking, and is designed to enable him to hold the produce of two vintages in the event of a bad market:-a very important advantage 


\section{New Roads and Old Cities}

to a producer. There is nothing of the model, or pleasure, farm about the place; it is all intensely practical. "It is an industry," said our host ; and indeed it is ; a fine example of industrial intelligence applied to agriculture. The presence on the farm of two motor-cars and an aeroplane is evidence that he is otherwise abreast of the movement.

It may be that our host is exceptionally gifted, both in enterprise and resources, but at any rate his example must be of great value. And the vistas all around of similar properties with pleasant houses bowered in trees and gardens suggest that it is followed. It is agreeable to learn that this industry meets its due reward. In I9Io it has been exceptionally profitable. The chief buyers of Algerian wines are the wine-shippers of Bordeaux and Macon, from whose cellars they emerge as claret and Burgundy. The complete failure of the vintage in Europe has caused a rise of fully fifty per cent in the price of the produce of Algeria. In this happy climate, sure of its winter rain and its summer sun, a failure of the vintage is unknown and almost inconceivable. Viticulture has become the most important 


\section{About Algeria}

of the industries in which Europeans in Algeria are engaged, and its prosperity is of great importance to the Colony. Before the French conquest, the use of wine being forbidden by the Koran, the vine was only grown to a small extent for its fruit; the raisin sucré of Khabylia was especially esteemed as a sweetmeat for dessert. The first colonists made experiments in the production of wine, but with insufficient knowledge and inadequate equipment. Wine-makers are an aristocracy among agriculturists; a high intelligence and inherited traditions count for much. The ravages of the phylloxera in France created the opportunity of Algeria. The wine-growers of the South thrown out of work were ready to emigrate, and the deficit in the mother country's production offered a great market for the Colony. Since that time the industry has made steady progression. In 18502000 acres were under cultivation as vineyards; in 1905 about 450,000 acres. The production of wine, which amounted to 370,000 gallons in 1878 , is now over $150,000,000$ gallons. The price obtained for wine exported is subject to very wide fluctuations. 


\section{New Roads and Old Cities}

In 1903 the $100,000,000$ gallons exported realized $f 4,000,000$. In 1906 110,000,000 gallons realized only $f \mathrm{i}, 600,000$.

Algeria has managed to keep comparatively free from the phylloxera; the provinces of Oran and Constantine, west and east, have suffered somewhat, but the central province, Algiers, has so far escaped. Energetic measures are taken to guard against the extension of the plague, and owners of vines which it is found necessary to destroy are compensated by the State. The policy of the Government is now not to encourage the extension of the vineyards, but to improve the quality of their produce. An effort should be made to find other outlets than the French market, and thus counteract the wide fluctuations in value which arise from its varying demands. Some attempt has already been made to produce rich dessert wines similar to those of Portugal and Madeira, of which there is a considerable consumption in France, and it would appear that there is no obstacle to its success. A delicious Muscat is already made, which might conceivably obtain a great vogue. 


\section{$I V-A$ GARDEN AND SOME BUILDINGS}

Jardin d'Essai-A lost opportunity-Some suggestions-The villas of Mustapha-A model museum-Arab art-Its origins-Its limitations-Its significance.

"There is an art to which I hold no key, A tangled maze of curve and line I see;

Do you, my brother, keener-eyed, discern A silent symbol of infinity?"

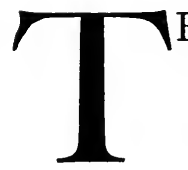

$\mathrm{HE}$ amateur gardener, especially if he has any knowledge of tropical or sub-tropical horticulture, will probably not be long in Algiers without visiting the Jardin d'Essai. This modest title is given to an extremely successful attempt at acclimatization, chiefly of tropical trees, on a large scale. It was established by the Government eighty years ago, and is now the property of the Compagnie Générale Algérienne, which grows vast quantities of young palms and other trees for export to Paris and London. 


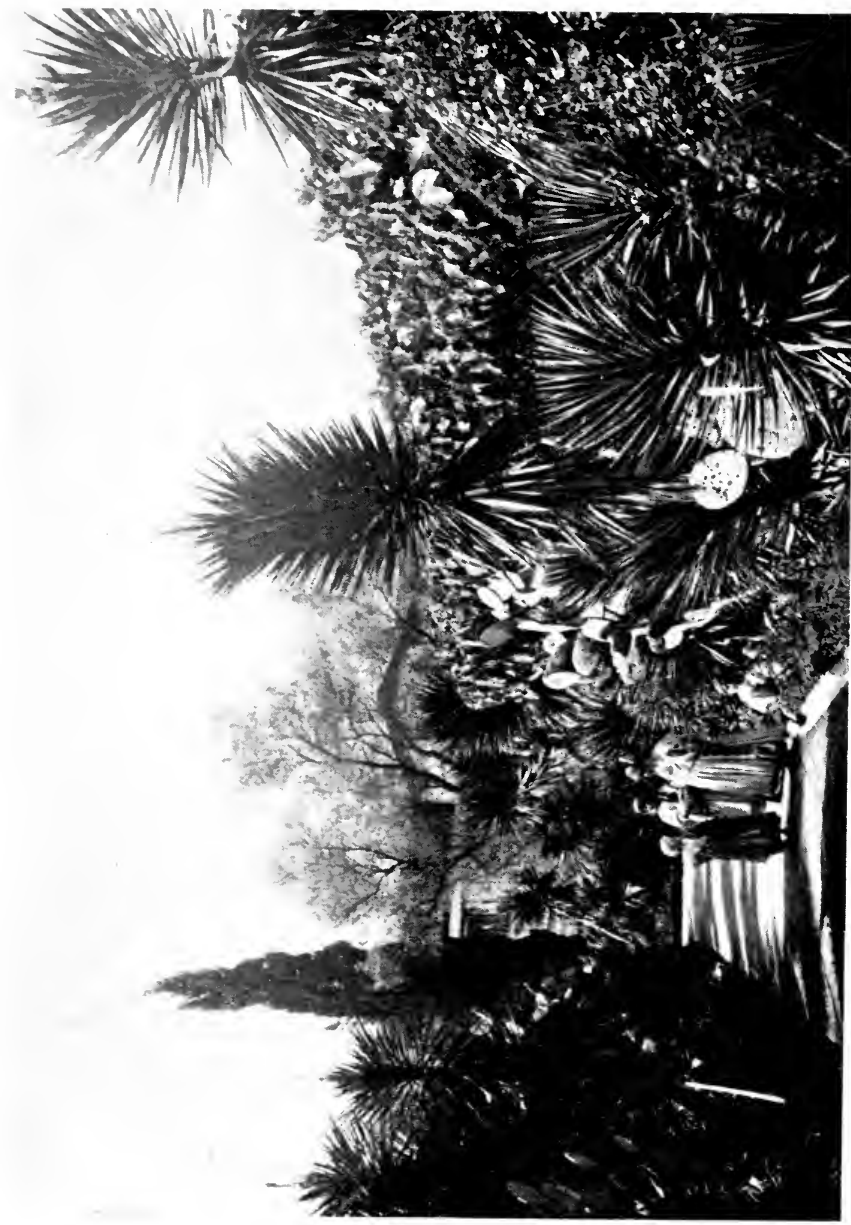

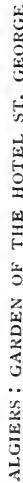


5

$x_{4}:$

6.

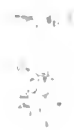




\section{$A$ Garden and some Buildings}

The garden in itself will be a disappointment to the garden-lover. It is a rectangular piece of ground, intersected by straight alleys, and with the exception of a pool of water at the southern corner, containing a small island, there is little attempt at what is called landscape gardening. And the possibilities of a water-garden are neglected. One wonders what an Algerian Wisley would be like. The whole aspect of the place suggests a not very well kept nursery garden, which in effect it is. But the wealth of its contents completely atones for its poverty in design.

Perhaps the most striking feature is an avenue of india-rubber trees, which have attained a gigantic size,-a height in some cases of sixty feet and a girth of twenty feet. It is a wonder that this garden was not "floated" on the London market during the recent " boom." At any rate, it does contain rubber trees, which it is understood some of the areas offered to the public did not. Another species of ficus covers a large space of ground, throwing down fresh roots from its lateral branches, and apparently prepared to travel in this way in every direction. It is un- 


\section{About Algeria}

fortunate that the trees and shrubs are very insufficiently labelled; occasional fragments of labels more or less indecipherable, and in some cases, I think, incorrect, may be discovered; but there is no systematic attempt to afford information. This ought not to be so in a garden for which the State is partially responsible.

The palms are very fine, and of many different species, including some great rarities which I am unable to name. All the commoner bamboos are in profusion, but being for the most part planted as hedges rather than as clumps they lose their natural effect. Various Yuccas vie with the india-rubber trees in their splendid growth. At the southern end of the garden, where the formality of the avenues gives place to a little wilderness, are some magnificent clumps of Strelitzia augusta, -finer in size and growth than I have seen elsewhere,-and towering above them are some lofty specimens of Chorisia speciosa from Brazil. In the drier spots are various species of aloe; and in the wetter papyrus flourishes exceedingly. The fantastic Monstrera deliciosa is quite at home, and imbeds its constricting 106 


\section{$A$ Garden and some Buildings}

coils in the palm-trunks, in a way which must be very painful to them.

Not much colour is to be expected in the early months of the year, but two or three Bougainvilleas make a moderate show, and both Bignonia venusta and $B$. Smitbii are in flower. The exquisite Plumbago Capensis is coming into bloom; also the single red Hibiscus and its less attractive double variety. A little trouble spent on this garden would soon make it one of the finest in the world, without in any way impairing its commercial uses. The material is there, and a little skill in rearrangement of walks and in grouping of specimens is all that is wanted.

Perhaps a friendly critic may venture to be also an adviser. It is to be presumed that Algiers welcomes the advent of strangers. And I find that the local press records with satisfaction that hotels are full, and also that great steamers with hundreds of tourists constantly arrive. These strangers do good to trade, and it may therefore be worth while to pay a little attention to their tastes, and to increase rather than diminish the attractions which draw them hither. Even if the inhabit- 


\section{About Algeria}

ants of Algiers care little about the beauty of the surroundings of their city, they are part of its essential charm, and should be preserved from the destruction which is everywhere threatening them. The ruthless felling of ancient trees, the obstruction of points of view, the vulgarization of pleasant places,these may seem little things individually, but in the mass they tell. There are, I believe, full powers to deal with such matters, and the Minister of the Interior has recently addressed to the préfets of France a circular calling attention to the necessity of safeguarding sites of artistic and natural beauty. Let Algiers lead the way, and she will not repent it. But she may some day bitterly repent inaction now.

Another suggestion. It would not be a great matter for the town to purchase a block of buildings in the old streets below the Kasbeh, to clean them out and to preserve them without undue restoration. Strangers wish to see what the old town was like, and are not all able to battle with the squalor and turmoil of the old streets as they are. Such a little natural museum would more than pay for its cost. And-this is a smaller matter 


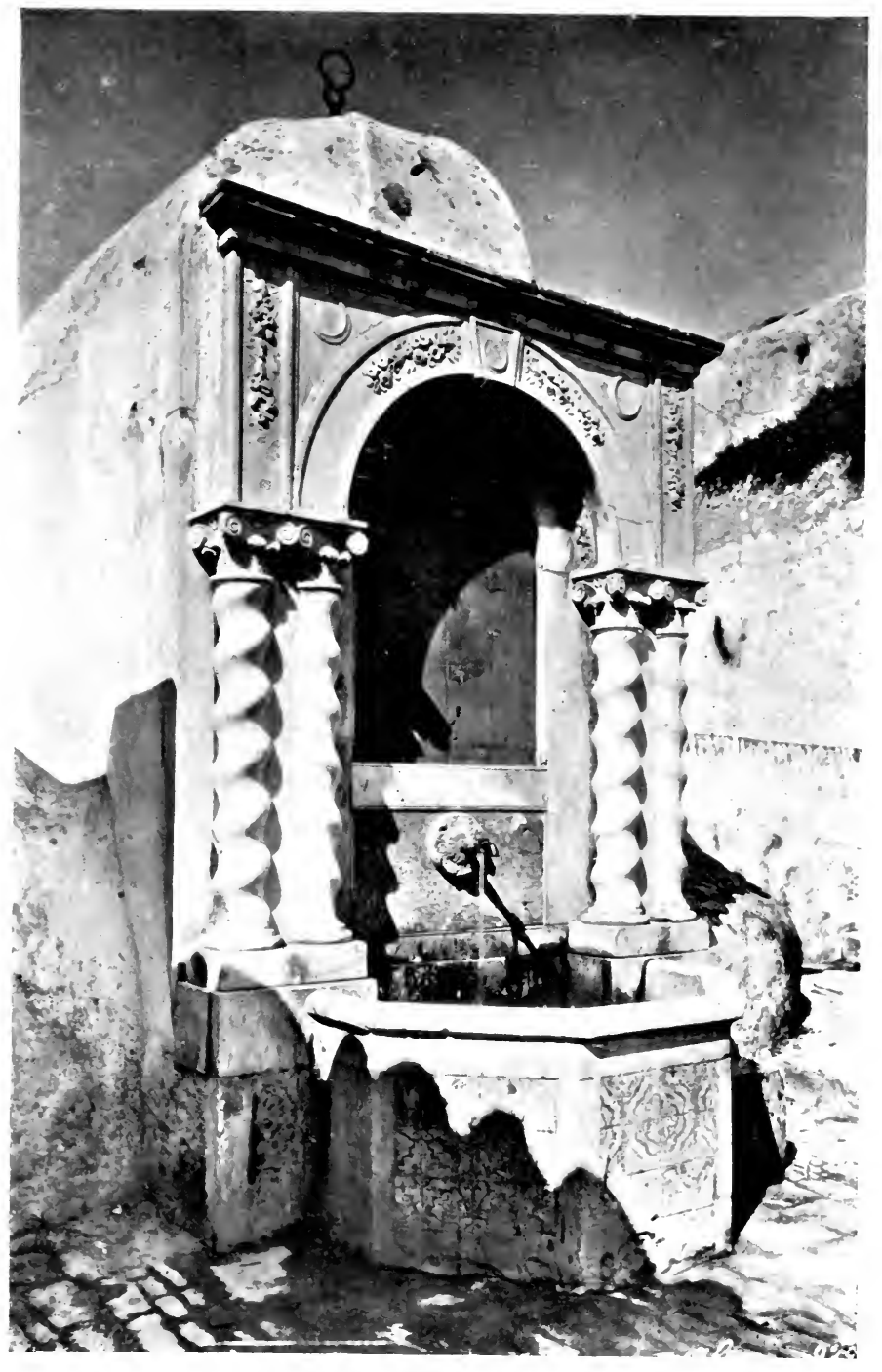

ALGIERS: FOLNTAIN IN THE KASBEH 


$$
4
$$




\section{$A$ Garden and some Buildings}

still-it would be for the convenience of foreigners if notices were affixed to public buildings, stating at what times they are opened to inspection. It is annoying, for instance, to arrive at the Bibliothèque in the morning and to find it closed, with nothing to indicate when it will be open.

I could extend these suggestions. But perhaps it would be too much to expect in a town largely peopled by Mohammedans that strangers visiting the mosques, or even passing in their neighbourhood, should be relieved from the importunities of irresponsible and worrying touts. The town is generally so well policed; the importunity of beggars is so trifling with what one suffers in Egypt, for example; that, like Oliver Twist, one asks for more.

The suburb of Mustapha takes its name from the last Dey but three who erected the palace now used as the official summer residence of the Governor. The vast sums he expended on it excited the anger of the janissaries, and led to his disgrace and death. There are many other Arab villas now modernized; they are well described by the 


\section{About Algeria}

artist Fromentin, a painter in words as on canvas: "To-day without exception they belong to Europeans. So the deep mystery which veiled them has vanished, and much of their charm has disappeared. The architecture of these houses has no great meaning when applied to European uses. We must therefore accept them for the pleasure of their exterior aspect, and study them as the graceful monuments of an exiled civilization. Inhabited by the people who built-I might say, dreamedthem, these dwellings were a creation both of poetry and genius. This people knew how to make prisons which were places of delight, and to cloister its women in convents where they were unseen yet seeing. For the day, a multitude of little apertures through stretching gardens of jasmine and vines; for the night, the terraces;-what more malicious, and at the same time more full of care for the distraction of the prisoners? The gardens resemble those playthings which are designed for the amusement of the Arab woman, that singular being whose life, long or short, is never anything but childhood. You see there only little gravelled walks, little rivulets in 


\section{$A$ Garden and some Buildings}

marble channels, where the water meanders in moving arabesque designs. The baths, too, suggest the invention of a husband at once a poet and a jealous lover. Imagine vast cisterns where the water is not more than three feet in depth, flagged with the finest white marble, and open through vaulted arches to a wide horizon. Not a tree reaches this height; when you are seated in these aerial bathing-places you see only sky and sea, and are seen only by the passing birds. We have no understanding of the mysteries of such an existence. We walk through the country to enjoy it; when we return it is to be indoors. This secluded life near to an open window, this motionless existence before so vast a space, this household luxury, this enervating climate and radiant country, the infinite perspective of the sea-all this must give birth to strange dreams, must throw the vital forces into disorder, and mingle a sentiment beyond the power of words to describe with the sorrows of captivity. But," concludes our author, " ne me trompe-je pas en prêtant des sensations très littéraires à des êtres qui assurément ne les ont jamais eues ?" 


\section{About Algeria}

Those who are fortunate enough to have access to some of these villas will find their original features of house and garden carefully preserved; the gardens improved and extended in accordance with more intelligent views of horticulture. Others may see in the spacious and well-ordered gardens of the Hôtel St. George, the largest of the hotels frequented by English visitors, what in the way of vernal loveliness the soil and climate of Algiers are capable of producing. In the grounds of the Hôtel Continental, another large house with a sunny situation and a magnificent view, are some curious and interesting trees, a dragon tree which is considered to be six hundred years old.

There is an excellent Algerian museum at Mustapha Supérieur in a pleasant garden, close to the Governor's Summer Palace, built with a court-yard, in the Moorish manner, an admirable form for a museum. It is laudably confined to Algerian antiquities and Arab art; there are no irrelevant South Sea Island curios; it has not been used as a receptacle for the rubbish of the local collector, a dumping-ground of the perplexed widow 


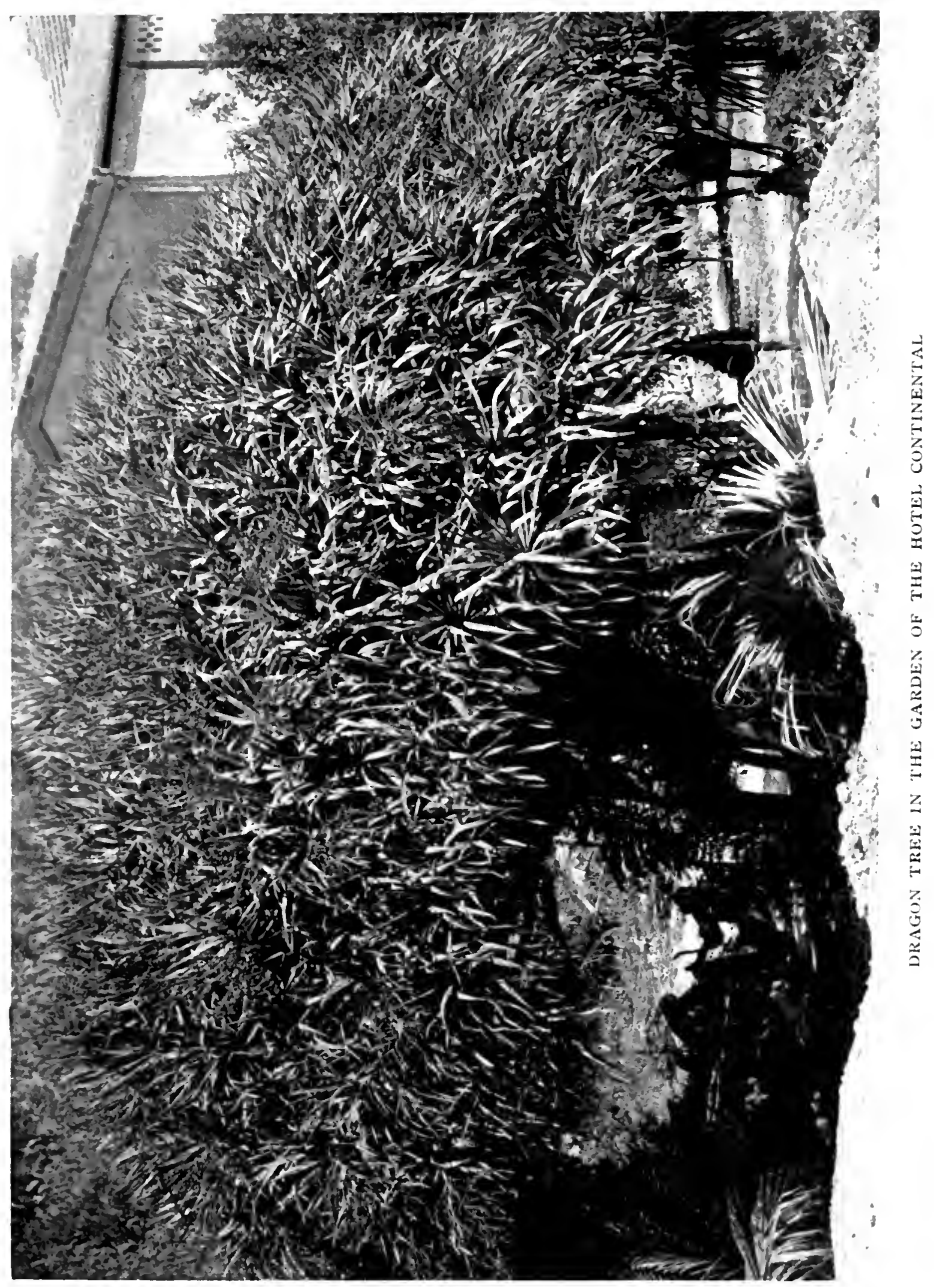


c. 


\section{$A$ Garden and some Buildings}

and the embarrassed executor. Algerian history is thoroughly represented; there are the flint implements of primitive man, a collection of Punic pottery from Gouraya, Roman antiquities of every kind, and numerous examples of Arab and Berber handicrafts. These treasures are exhibited with the taste which distinguishes the French in such matters, as is evidenced in their dressing of shopwindows. Of the Roman antiquities perhaps the gem is a bronze figure of a boy with an eagle, two feet high, and of fine style. It was found at Lambessa. From Lambessa come numerous other exhibits, including some gold coins of the period of Septimius Severus, an emperor of African origin, of Julia his wife (with filigree mounting), and Caracalla and his son, of Macrinus and Severus Alexander. These are in mint condition. And there is a very fine gold medallion of Postumus. There are numerous mosaics,-in Roman Africa mosaic pavements were very popular and well executed, -marbles of all kinds from Cherchel, and a very interesting stone tablet recording the rules for the distribution of water from an aqueduct to Roman colonists. The Arab 


\section{About Algeria}

portion includes arms, jewellery, the elaborately embroidered saddlery of Arab cavaliers, pottery, carpets, woven stuffs, - a fine assortment of Arab and Berber handiwork. Altogether a most creditable museum, - a very model of what a local museum should be. In a neighbouring building is a "Forestry" collection;stuffed examples of Algerian wild animals, and fine specimens of Algerian woods, and so on. Some magnificent examples of slabs of the native $T$ buja are worth notice.

As with other public buildings in Algeria, the usefulness of this museum is somewhat curtailed by the short time it is open,-only in the afternoon and not every day, -and, what is worse, by the absence of any notice of the hours during which it may be visited. In my ignorance I tried to enter on two or three occasions. Goaded to desperation one morning I rang the bell, and found the amiable custodian at leisure to admit me, but only by favour. Such a collection is worthy of a notice-board in French, Arabic, English, German, Spanish, and Italian, setting forth the hours it is open, and to a foreigner (I make the suggestion with diffidence) it appears 


\section{$A$ Garden and some Buildings}

that the morning hours should not be forgotten. This is too good a museum to be circumscribed by such antiquated and provincial arrangements as prevail at present. The object of a museum should be to get people to come in, not to keep them out. I was informed that it was closed on Monday afternoon because there were too many people about! The British workman's Monday is evidently not the insular institution I had supposed. But a museum is not a fortress.

We are wont to speak of "Arab Art," but the term, if consecrated by usage, is incorrect and misleading. There is, in fact, no such thing. The Arab has never been an artist. The nomad had of necessity no architecture, and architecture is the mother of the arts. Artistic incapacity and an effort to break away from anthropomorphism in religion went hand in hand among the Semitic races;"Thou shalt not make to thyself any graven image, nor likeness of any thing that is in heaven above, or in the earth beneath, or in the water under the earth." And when Solomon builded his temple he turned for assistance to the King of Tyre; and one 


\section{About Algeria}

Hiram, a brassworker of Tyre, "wrought all his work." To this day the Jews, who have excelled in finance and statecraft, in literature and in music, have made little mark in art.

The rise of Islam is an extraordinary phenomenon. In one generation the Arab is a wanderer, half patriarch, half brigand, pasturing his flocks on the verge of the cultivated lands of more civilized peoples, and snatching such prey as hazard brought within his grasp; in the next he is a conqueror ruling from the Indian Ocean to the Atlantic, and threatening to extinguish Christendom. On the vanquished he imposed his religion and his social code; he had no art to impose. Having become by force of conquest and the exigencies of government a dweller in cities, he showed his incapacity to understand the work of his predecessors in such eccentricities as re-erecting their fallen buildings with the columns inverted, using the capital as base, and the base in the capital's place. As architects he employed the natives of the countries he had overrun, in Egypt Copts and Greeks, who reproduced Byzantine forms and fixed the typical lines on which the development I16 


\section{$A$ Garden and some Buildings}

of "Arab art" was to take place. In this deference to local tendencies is to be found the origin of the wide divergencies of art in the Mohammedan world,-of Persian art in the east, and Moorish art in the west. The conquered and converted peoples continued to build, as far as the main plan was concerned, in the same way as they had built before their conversion, adapting their previous methods to present needs, and to the requirements of their conquerors.

In Barbary the development of art followed closely that of Spain. The Moorish art of Spain was chiefly Roman or Byzantine in origin ; the first mosque built, that of Cordoba, is said to have been designed by architects from Byzantium. Columns used in its construction were brought from the ruins of Merida and other Roman towns, and even from distant parts of the Mediterranean. From this commencement sprang the later glories of Moorish art, exhibited in their most splendid developments at Granada in Spain, and Tlemçen in Algeria.

If in the scheme of its buildings Moorish architecture followed earlier examples, the 


\section{About Algeria}

Byzantine basilica and the Roman house, in its decorative features it was more distinctively Mohammedan. Yet if the Semite nourished his traditional aversion from the graven image, if the Prophet forbade idolatry and his disciples extended the prohibition to the portrayal of the human body, and enjoined that only trees, flowers and inanimate objects should be depicted; it is nevertheless necessary to seek some deeper cause for the objection of the western Mohammedans to any artistic representation of animal forms. This objection was by no means universal in the Mohammedan world. The Persian rejoiced in his pictures and statues. The explanation may be found perhaps in the zeal of the iconoclasts which had rent North Africa before the Arab invasion. Fathers of the Church had thundered against images ; humbler Christians, such as the Copts in Egypt, had striven to dissociate their art from materialistic suggestions, and to find in geometric designs some expression of their aspirations for the infinite. But Hellenism, with its delight in nature, and especially the human form, was still dominant in Christian art. It disappeared 


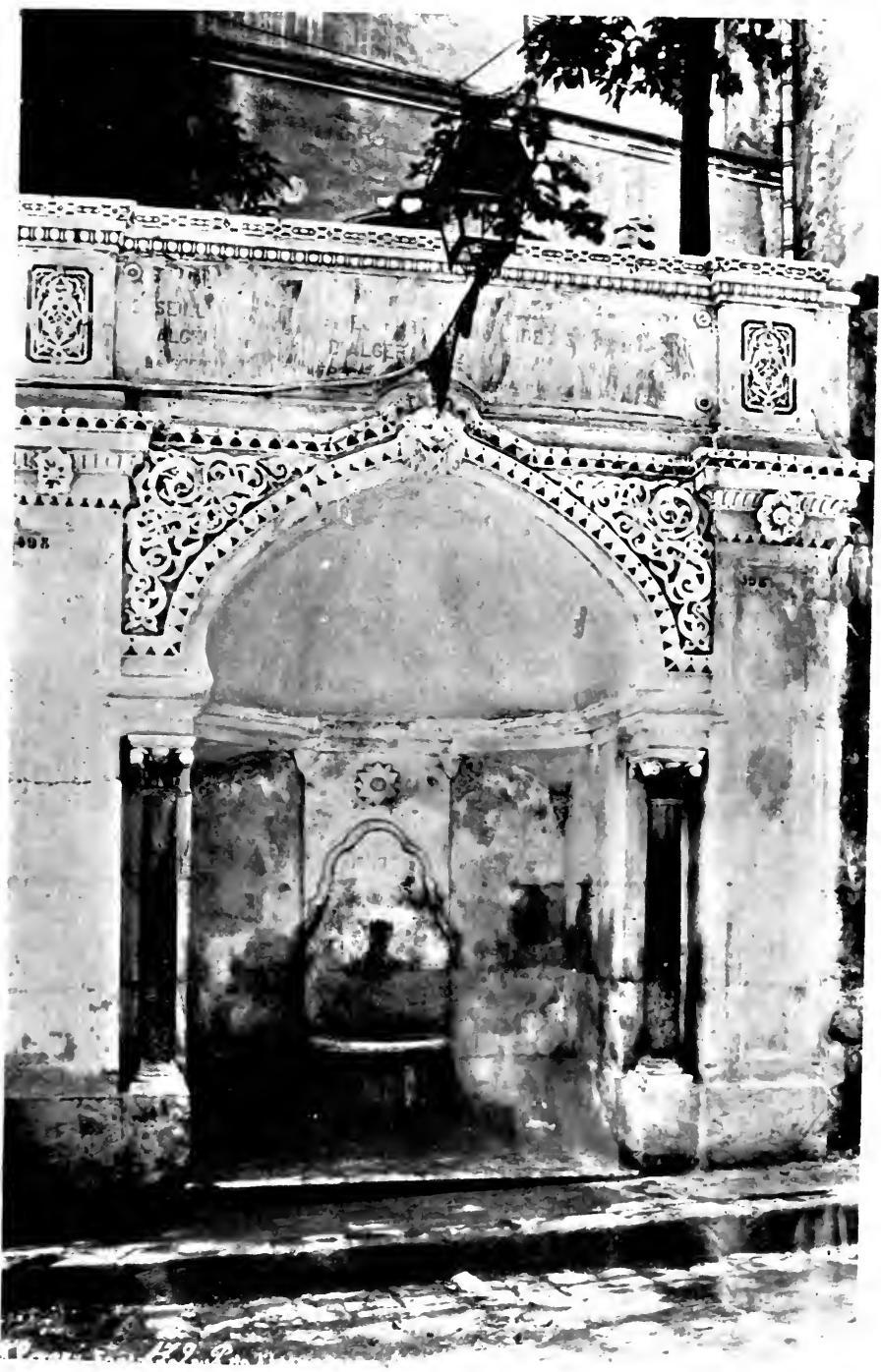

ALGIERS : FOLNTAIX, RLE DE LINTENDANCE 


\section{$A$ Garden and some Buildings}

before the onslaught from Arabia. The Coptic builder saw his opportunity. His abstract ideas fitted exactly with those of his new master. In his rhythmical representations of foliage, his polygonal figures and intersecting angles, may perhaps be found the germ of the characteristic motives of Mohammedan decoration.

Its elements may be divided into three groups;-inscriptions in writing, and interlacements, rectilinear and curvilinear. It will be found that almost all Moorish decoration falls under one of these three heads. The inscriptions as a rule are not historic, but ornamental, verses of the Koran, pious sentences and so forth. The style is at first sober and monumental, more stately than the cursive hand in ordinary use. As we should expect, it became in time more elaborate and fantastic, harmonizing well with the decorative interlacements which commonly surround the lettering. The inscriptions themselves are often in geometrical form, so as to give at first sight the impression of a pattern; for instance, a sentence may be repeated four times around a central letter. 


\section{About Algeria}

To the variety of geometrical and curvilinear interlacements there is obviously no limit. Angles, straight lines and curves are frequently combined in the style we denominate arabesque, a style which has prevailed far beyond the limits of Arab conquest, and is particularly a feature of Venetian art. Late examples show great development, especially on floral lines. Leaves of particular trees, notably the palm, are represented. But a mathematical suggestion does not cease to prevail. The passion for interlacement and for excessive decoration of surface gives rise to curious vagaries,-such are the intricate intersection of arches, the breaking up of the arch itself into subsidiary arches, and the "stalactites" which commonly adorn the roof of the mibrab, the Holy of Holies. It is not without interest when visiting a mosque to note these developments and to strive to trace them to their original elements.

Our insight into the Arab mind is so limited, we have ourselves so slight an inclination to the symbolic and the mystic, so strong a preference for directness in art and speech, for "straight-flung words and few," that we 


\section{$A$ Garden and some Buildings}

may well hesitate to dogmatize in such a matter as Moorish decoration. In the light of our own tame submission to a superabundance of ecclesiastical and domestic ornament which is without significance we should regard it as merely a habit of clothing blank spaces with conventional markings. Yet it may be that the spiritual dreamer, ever intent on the conception of an abstract deity, rejecting with scorn the idea of a God made flesh and dwelling among men, finds in the geometrical expressions of unending line and angle, in the interminable intricacies of the interlacing curve, some harmony with his own longings, and some suggestion of the Infinite. 


\section{V-SWORD AND PLOUGH}

Great events and trivial causes-The Dey's fan-France rousedEngland as dog-in-the-manger-The French expedition and conquest-Clauzel-Abd-el-Kader-Bugeaud.

"They shall beat their swords into ploughshares."

ISAIAH.

T $T$ is naturally impossible for a traveller to traverse Algeria without being constantly conscious of the effects of the French conquest. His own presence there otherwise than as a Christian slave is one of them, and not the least important one for him. But in the course of his journeyings he will be so frequently informed of important incidents in the series of campaigns, of the connection of localities he is visiting with some phase of victory or defeat, that a short résumé of the lengthy transactions may not be out of place. With many side-issues the story resolves itself in the end, as such war-histories often do, into a struggle for the mastery between two great men. The Frenchman won the rubber. 


\section{Sword and Plough}

Stern as was the lesson which Lord Exmouth inflicted, it was soon forgotten, and the ingrained habit of centuries reasserted itself. A subsequent Dey set himself to re-create a fleet, and in 1820 he had forty-four vessels with 1560 sailors. Fresh trouble arose with the British consul, and the weakness of the admiral who was sent to support him only made matters worse. The Dey refused to see Mr. McDonell, who had been forced to leave, and treated Mr. St. John, who replaced him, with ignominy. "All the disgraceful ceremonies in the intercourse between the representative of Great Britain and the Turkish authorities were continued. The consul was obliged, the moment he came in sight of the Dey's palace, to walk bareheaded in the hottest sun; in waiting for an audience he had to sit on a stone bench in the public passage; he could not wear a sword in the Dey's presence, nor ride to the palace, though his own servants, if Mohammedans, might do so." And the corsair fleet began once more to harry the coasts of France and Spain.

In the early days of the Turkish domination the corsairs had been influenced by political 


\section{About Algeria}

preferences. They had especially waged war against the Spaniards, who had expelled the Moors, and whose sovereign, Charles V, was the enemy of the Sultan. They respected the vessels of Francis I, the Sultan's ally. So may even pirates follow the dictates of conscience. But as time went on the high character of the Algerian corsairs suffered some abasement through association with the renegades of Christendom, and French and Spanish vessels met a like fate,-all was fish that came to their net. The French, who had formerly felt that the Spaniards were getting no more than their deserts, and had even afforded Kheir-ed-Din a temporary refuge in the port of Marseilles during a storm, were naturally hurt at the ingratitude of these proceedings. They went so far, in the reign of the Grand Monarque, as to bombard Algiers on two occasions, -with the customary result. Their fleets sailed away; Algiers rebuilt itself, and proceeded upon its piratical way. No one has ever rivalled the Deys in the art of taking a beating, and coming up again with a smile,unless it be their ultimate conquerors.

Great changes in the history of the world 


\section{Sword and Plough}

have often been, or have seemed to be, the result of accident. Wars have been waged, conquests effected, empires created, not of settled intention and design, but as the outcome of the personal quarrels, and the personal ambitions of individuals, less, in modern times at any rate, of sovereigns than of subjects. The British Empire has been created rather in spite of than by the aid of the governing powers of Great Britain. Cecil Rhodes is but the latest of the long line of Englishmen who imposed imperial responsibilities on a halfhearted England. Governments seldom dream imperial dreams; they are more concerned to keep their seats. Sovereigns like George III may lose an empire. Mere accidental citizens, as Clive or Rhodes, may create one.

So this fertile North Africa, through history the shuttle-cock of Asia and Europe, with an illimitable hinterland of "rather light soil," to quote the words of a statesman who had little sympathy with African conquest, became French because an Algerian Dey struck a consul with his fan. This incident aroseas modern international incidents frequently arise-out of a financial dispute. Certain 


\section{About Algeria}

Jews of Algiers had a claim against France for corn supplied during the Napoleonic wars. The Dey pressed this claim as his own; and being dissatisfied with the delay in settlement he made a violent scene with the consul, "et s'oublia jusqu'à le toucher de son chassemouches." Apologies were demanded and refused, and for three years, from 1827 to 1830 , France endeavoured to blockade the port of Algiers. The Dey Hussein continued obdurate. So little repentant was he that when the Provence entered the port in 1829 , having on board a French admiral, charged to make a last effort at negotiation (for the blockade was costing seven millions of francs a year and effecting nothing), all the batteries opened fire on her. Even now the French ministry was reluctant to make war, and proposed to the Sultan of Turkey that Mehemet Ali, Pasha of Egypt, should bring the Barbary states under his rule. The Sultan refused his authorization, and an expedition was decided on. France was destined to become an African power, "un peu malgré elle."

The naval authorities were strongly opposed to a military expedition; it would, they 126 


\section{Sword and Plough}

declared, be absolutely impracticable to land an army with its indispensable materiel; and former experience, especially the failure of Charles V, appeared to support their view. But the French Cabinet decided to make the attempt. With the exception of England, the European powers were complaisant. England demanded explanations as to the object of the preparations. M. de Polignac in a circular note explained that his master desired only to suppress piracy, slavery and the tribute paid by Christian nations to the Dey. England was not satisfied and asked for a formal renunciation of a policy of annexation. The President of the Council replied to the British ambassador that the King was not led by any sentiment of ambition, that he was not aware that he had need to ask the permission of anyone to avenge an insult to his flag; that he had already made known his intentions, and that his word ought to be sufficient guarantee. England returned to the charge. M. de Polignac then produced a second circular note in which he declared that "if Algiers fell into the power of the French army the King would examine in conjunction with his allies 


\section{About Algeria}

what new order of things it would be fitting to establish for the benefit of Christianity." England complained that this note contained no formal engagement not to keep Algiers; the French minister put an end to the discussion by declaring that the King's communications required no further development.

It is interesting to recall these diplomatic amenities; mutatis mutandis they bear strong resemblance to certain international passages at the time of the English occupation of Egypt. But France does not seem to have given any undertaking that her operations should be only temporary.

If his memoirs are to be trusted, Admiral d'Haussez, the French Minister of Marine, lacked the diplomatic suavity of his colleague. Even a sailor's bluffness hardly covers the tone of a declaration he made to the British ambassador. "The King wishes the expedition to be made, and it will be made. France laughs at England. She will do in this instance what she likes, and will put up with neither control nor opposition. We are no longer in the days when you dictated laws to Europe. Your influence 128 


\section{Sword and Plough}

rested on your wealth, your ships and your habit of domination. All that is past. I suppose you are not willing to compromise what remains of your influence by going beyond threats. But if you wish to do so, I will give you the means. Our fleet is already assembled at Toulon, and will be ready to sail in the last days of May. It will call at the Balearic Isles, and it will land the troops to the west of Algiers. If the fancy takes you, you may meet it."

France had her way without interference; the admiral's prophecy (recorded after the event) was fulfilled to the letter. An army of 35,000 men under General Bourmont was transported in 300 vessels, and disembarked with no great difficulty at Sidi Ferruch, about fifteen miles to the west of Algiers, on June I4th, 1830. The landing was unopposed, Hussein having expected it to take place to the east of the town and collected his army there. A few days later the Dey's son-inlaw and general, Ibrahim, came into conflict with the French troops and was defeated. A second attack had the same result. The French army marched on Algiers, laid siege 


\section{About Algeria}

to Fort l'Empereur, so called because it stood on the heights above the town where Charles V had pitched his tent. The French soldiers knew only one Emperor, and promptly called it Fort Napoleon. The Turkish garrison blew up the fort and fled, and Algiers lay at the mercy of the invaders.

It appears that Hussein was ready to resist to the death, and sooner than submit to blow up the city. But disaffection appeared among his troops, who sent an emissary to Bourmont, offering the Dey's head as a token of conciliation. The Dey then decided to treat; he was willing to make every reparation for the insult offered to the consul, to abandon his pecuniary claims and to pay the cost of the war. But Bourmont would have nothing but the surrender of the city and its forts. The Dey was to be at liberty to retire to some place to be fixed on, with his family and his riches. As regards the inhabitants,-_"l'exercice de la religion mussulmane restera libre. La liberté des habitants de toutes les classes, leur religion, leurs propriétés, leur commerce, leur industrie ne recevront aucune atteinte, leurs femmes seront respectées: le général en chef en prend l'en- 


\section{Sword and Plough}

gagement sur l'honneur." These terms were accepted; the French army entered Algiers on July 5 th; and it appears that the conditions were fairly well observed.

An eye-witness has described the attitude of the population. "Algiers," he says, " on the entry of the French, did not present the sad and desolate aspect of a conquered town. The shops were closed, but the traders, seated quietly before their doors, seemed to await the moment for opening them. You met here and there groups of Turks and Moors who appeared more indifferent than alarmed. A few veiled Mohammedan women could be seen peering through the narrow windows of their dwellings; Jewish women with greater boldness filled the terraces of their houses without exhibiting any surprise at the novel spectacle. Our soldiers threw everywhere eager and curious glances, and all they saw filled them with astonishment at a city where no one seemed astonished at their presence. The resignation to the will of God which is so profoundly graven on the spirit of the Mussulman, the sentiment of France's power, and her well-known generosity, all made for con- 


\section{About Algeria}

fidence ; and it was soon established." ${ }^{1}$ With such ease and light-heartedness did France enter on her career of African conquest. Her troubles were to come.

The policy to be pursued was the first of them. The expedition had achieved its punitive object, Algeria appeared to be poor and sterile, and there was much to be said for abandoning it altogether. At the other extreme was the proposal to attempt a complete and definite conquest. A middle course was adopted,-to occupy only certain important points on the coast and in the interior. It is easy to be wise after the event; our own colonial experience is full of evidence of the futility of half-measures; and we need not claim much perspicacity for observing that France missed the golden opportunity for occupying the country when the central Government, such as it was, had been destroyed. But, for all the brave words of the truculent admiral, she doubtless felt some diffidence in view of her declaration to Europe, and the continued hostility of Great Britain was not without its effect. France's own

2 Pelissier de Reynaud, "Annales Algériennes." 


\section{Sword and Plough}

political position, too, was in a very disordered condition. On the 18 th of August a revolution took place, Louis Philippe was proclaimed King and Bourmont was recalled.

For the next ten years, from 1830 to 1840 , what was known as the policy of Restricted Occupation was pursued. Certain ports on the coast were occupied-Oran, Bougie, Bône, etc.-and attempts were made to bring the plain of the Metidja under French control by placing garrisons in such towns as Medea and Blidah. The army of occupation was much reduced, and Clauzel, the general in command, endeavoured to raise native auxiliary troops, with small success. He was, at any rate, a master of bombast. Having occupied Blidah and ascended one of the passes of the Atlas, he addressed his troops: "Soldats! les feux de nos bivouacs qui, des cimes de l'Atlas, semblent dans ce moment se confondre avec la lumière des étoiles, annoncent à l'Afrique la victoire que vous venez de remporter," etc. This pronouncement was followed by the withdrawal of the garrison and a hasty retreat to Algiers. Early in I831 Clauzel was recalled. His successors, Berthezène, the duc de Rovigo 


\section{About Algeria}

and Voirol, essaying a great undertaking with inadequate means, had no better fortune.

Under Voirol General Desmichels was sent to Oran with the object of establishing order in the west. The tribes were in arms, and at their head-quarters at Mascara had chosen as their general a celebrated marabout, or holy man, named Mahi-ed-Dine, who, having attacked Oran several times without success, resigned the command to his son, Abd-elKader, then only twenty-four years of age, but destined to become one of the greatest leaders of modern times. He was, says Camille Rousset, "of middle height, but well made, vigorous and untiring. $\mathrm{He}$ was the best among the best horsemen in the world. Physical qualities are highly valued by the Arabs; Abd-el-Kader had more-the qualities which make men conquerors: intelligence, sagacity, strength of will, genius to command. In eloquence he was the equal of the greatest orators, and could bend crowds to his will. He spoke in serious and measured tones, and was sparing of gesture, but his pale face was full of animation, and under their long dark lashes his blue eyes darted fire." It may be 


\section{Sword and Plough}

remarked that the blue eyes point to a Berber, rather than an Arab origin. Such was the man who for years to come was to bid defiance to the French.

Their first dealings with him were unfortunate. Desmichels arrived at Oran in the spring of I833. Finding that he could make no headway against Abd-el-Kader, who from his capital of Mascara was preaching a holy war for the extermination of the infidels, he concluded with him a treaty which enormously increased the Arab's authority. Abd-el-Kader was described in it as Emir; all practical power was placed in his hands; and he was permitted to purchase arms and ammunition in French towns. No mention was made of French sovereignty. The treaty, though contrary to the instructions of the French Government, was accepted by it in the belief that it assured peace. Difficulties soon arose. Desmichels was recalled; his successor, Trezel, at the head of a column of 1700 men, was attacked by Abd-el-Kader in the marshes of $\mathrm{La}$ Macta, and defeated with the loss of a third of his force.

The prestige of this victory brought many 


\section{About Algeria}

waverers to the Arab leader's flag. But France's disaster brought home to her the seriousness of the position, and in the end the defeat did more towards the ultimate conquest than a victory would have done.

Clauzel, who had left Africa almost in disgrace in $183 \mathrm{I}$, was sent back in full command in 1835. He alone of the French generals had exhibited any military qualities. His grandiose projects have been justified by events. His main plan consisted in occupying Mascara and Tlemçen in the west, Medea and Miliana in the centre, and Constantine in the east. Of Tlemçen and Constantine he said, "Si vous n'occupez pas ces deux Gibraltar de la Régence d'Alger, vous n'en serez jamais les maitres." His failure was due to his attempt to effect these objects with the inadequate means with which he was supplied. He commenced by advancing against Abd-el-Kader, who retired before him. Having occupied Mascara and Tlemçen, he returned to Algiers, whereupon Tlemçen was promptly besieged by the Arabs. At this point the great Frenchman, destined to overthrow the Arab power and to conquer Algeria, appeared on the scene. 


\section{Sword and Plough}

General Bugeaud was sent to command in the west. He was personally opposed to conquest, and regarded French intervention in Algeria not only as having been badly conducted, but as initially a mistake. These views did not prevent him from putting his hand to the plough. He began by revolutionizing the methods of warfare; in spite of the opposition of his officers, he dispensed with heavy trains of baggage and artillery, lightened the loads of the soldiers, and carried their provisions on mules. Attacking Abd-el-Kader at La Sikkah he inflicted on him a signal defeat, his native auxiliaries pursuing the flying enemy with fury and slaughtering them in great numbers. Bugeaud then returned to France.

Meantime Clauzel, having had some success in the neighbourhood of Algiers, attacked Constantine, but was ignominiously repulsed, and was recalled. The city fell the following year to General Valée. In I837 Bugeaud was sent back to Oran, with instructions to make terms with Abd-el-Kader on the basis of surrendering to him the province of Oran in consideration of his recognizing the sovereignty of France and paying tribute. The two leaders 


\section{About Algeria}

met and negotiated the treaty of the Tafna. It was all in the Arab's favour; the tribute fixed was nominal, the sovereignty question ignored. In native eyes Abd-el-Kader became a veritable monarch, his territory was assured to him and he had leisure to gather his forces for a further struggle. We must suppose either that Bugeaud's private preferences carried him away, or that the situation in the west was too desperate to warrant his insisting on better terms. For two years peace reigned, but in 1839 Abd-el-Kader proclaimed a holy war. Arabs and Khabyles invaded the Metidja and burnt the farms of the French colonists. Hostilities lasted for two years with no decisive result. In October, I840, the GovernorGeneral, Valée, was recalled, and Bugeaud was sent out in supreme command to inaugurate a new policy.

The half-hearted efforts of ten years were at an end, l'occupation restreinte was to give way to l'occupation totale. France set herself at all cost to occupy effectively the whole territory of Algeria up to the desert. She had missed her chance at first. "Occasion," says Bacon, "(as it is in the common verse), 


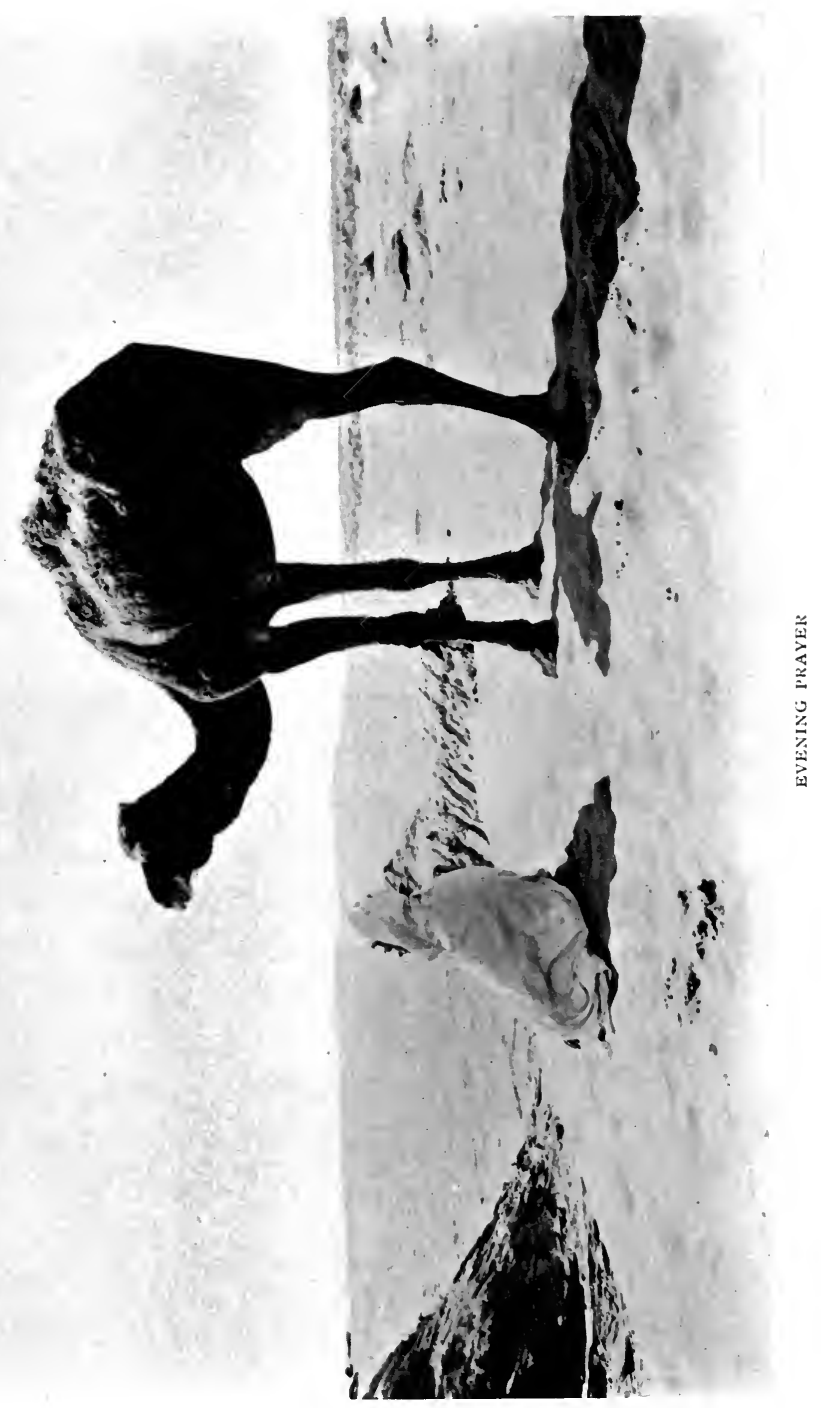




\section{Sword and Plough}

turneth a bald Noddle, after she hath presented her locks in Front and no hold taken." The unwise temporizing with Abd-el-Kader had enormously increased the difficulties of the position. But there was to be no more dalliance.

Bugeaud was one of those born leaders to whom the exigencies of the occasion are more important than military tradition. To seek the enemy's force and to destroy it was for him a leading principle, as it has been for our great naval commanders. He abolished the garrisons of his predecessors, and substituted for them mobile columns. He believed, and proved, that the manœuvres of such columns were far more effective, even for the protection of colonized districts, than the occupation of definite points. In the main he relied on infantry, supported by a light and very mobile artillery. The a priori view that cavalry is necessary to meet a mounted enemy found in his operations no support, however useful it may be for surprises and pursuit. Can it be that the famous telegram to our Colonies at the beginning of the last South African War, - " infantry preferred," - was due to a states- 


\section{About Algeria}

man's study of the memoirs and correspondence of Marshal Bugeaud?

$\mathrm{He}$ even conceived the idea of mounted infantry, mounting his men on mules or camels as occasion served. He prohibited the use of waggons for baggage and provisions, and dared, in spite of the indignant protests of his cavalry officers, to use the troop horses to carry rice and corn. Sprung himself from the ranks, - he had fought as a corporal of the guard at Austerlitz,- -he understood the soldier's needs, powers and limitations; and was in turn trusted and beloved,-le père Bugeaud he was affectionately called. Such was the man who was to win for France her African empire.

It is unnecessary to recount the details of the long duel between Bugeaud and Abd-elKader. Step by step the Arab leader was driven from the fertile regions to the high plateaux, and with every reverse his authority over the tribesmen waned, even if his own resource and resolution never failed. A severe blow was dealt in the spring of 1843 . Abd-el-Kader had established a vast caravan, known as the smalah, comprising the families of 


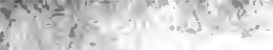




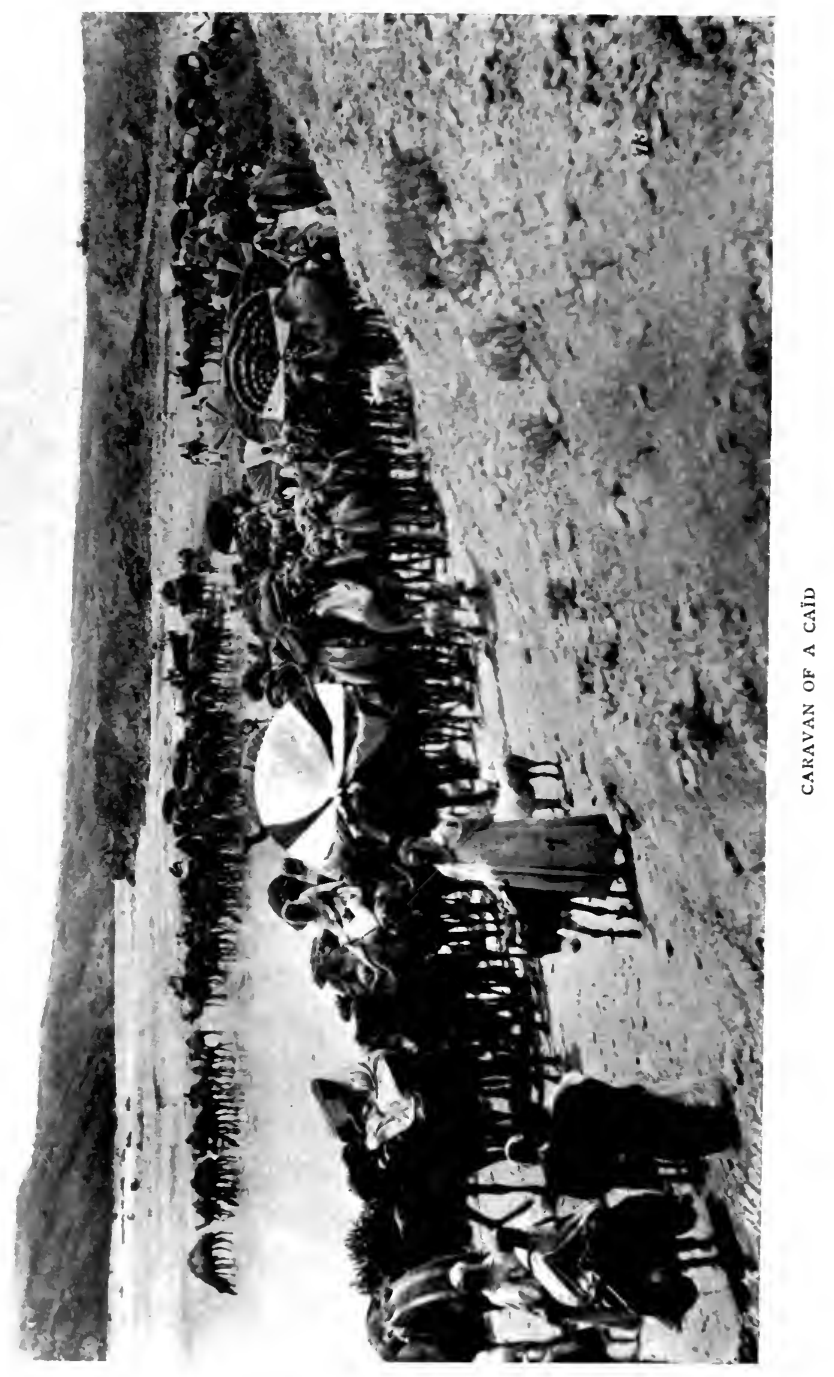




\section{Sword and Plough}

his forces, their flocks and herds, and a crowd of non-combatants who abandoned their homes and followed his fortunes rather than submit to the foreigner. It was, as Bugeaud said, "la capitale ambulante de l'empire arabe." It was reputed to contain 40,000 persons, defended by 5000 combatants. The young Duc d'Aumale, son of Louis Philippe, was charged with its capture. Having located its position at Taguine, he attacked it with a force of 600 horse, without waiting for his infantry, consisting of I 300 men. The suddenness of his onslaught broke down all resistance ; the defenders fled, leaving much booty and many thousand prisoners in the hands of the French. For some months more Abd-el-Kader continued to make a futile resistance, but finally fled to Morocco. In July Bugeaud received the fitting acknowledgment of his success, and was named Marshal of France.

France now came into conflict with the Empire of Morocco,-the commencement of a page of history still unfinished. The Sultan, perhaps against his own inclinations, was compelled by the sympathies of his people to espouse the cause of the Arab leader. 


\section{About Algeria}

His son led an army of 40,000 men to the frontier. Bugeaud, with a force of 8000 , met him on the banks of the Isly. The night before the battle Bugeaud addressed his officers, who were assembled at " un punch" to welcome some comrades arrived from France: "With our little army of 6500 bayonets and 1500 horses I am going to attack the army of the Prince of Morocco, which amounts, according to my information, to 60,000 horsemen. I would the number were double, or thrice as great, for the greater would be its disorder and disaster. I have an army; he has only a mob. And I will explain to you my order of attack. I give my little force the form of a wild boar's head. The right tusk is Lamoricière; the left tusk, Bedeau; the snout is Pelissier; and I am between the ears. Who can stop our penetrating power? Ah! my friends, we will cut our way into the Moorish army as a knife cuts butter."

This new eve of Austerlitz was followed on the morrow by an overwhelming victory. By midday the Moors were in flight and their camp of a thousand tents, with all their artillery, was captured. The bombardment 


\section{Sword and Plough}

of Tangier and Mogador by the Prince de Joinville assisted to bring the Sultan to his senses, and peace was concluded by the Treaty of Tangier.

But the troubles of the French were not over. In 1845 the indomitable Abd-el-Kader, having recruited 2000 men in the Sahara, appeared in the west and raised the whole province of Oran; farms were burnt, crops destroyed and bridges thrown down. Bugeaud, recalled from France, set himself to make an end. He collected a force of 100,000 men, divided into eighteen columns. A mighty hunt began. Abd-el-Kader was everywhere in turn. As ubiquitous as De Wet, he was now in the Tell, now in the high plateaux, now endeavouring to raise the mountaineers of Khabylia. But the end was inevitable. The tribesmen whom, having raised, he left to their chastisement, grew weary of the process. "You are like the gad-fly," they said to him, "which arouses the bull. When you have done your work of irritation you disappear, and it is we who bear the brunt of the blows." After a fruitless effort to obtain fresh aid from Morocco, he was captured on the frontier by 


\section{About Algeria}

Lamoricière and sent to France. $\mathrm{He}$ was subsequently allowed to retire to Syria, where he lived on a pension paid by the French Government till his death in 1883 . He left a name venerated by his countrymen and respected by his conquerors. The French have had to face serious insurrections since, but no native leader has arisen to repeat the exploits or rival the fame of Abd-el-Kader.

Bugeaud was more than a great soldier; he was a statesman and a colonizer. He chose as his motto, "Ense et aratro." He held that, except as a forerunner to the plough, it was useless to draw the sword. The military and civil control of a subject population, such as the English rule in India, and in recent days the pax Gallica of the Sahara, may be an excellent undertaking for a people of superabundant energies; for Bugeaud the conquest of Algeria was only a necessary preliminary to its organization as a French colony. "La conquête," he said in his first proclamation, "serait stérile sans la colonisation. Je serai donc colonisateur ardent, car j'attache moins de gloire à vaincre dans les combats qu'à fonder quelque chose d'utile et de durable." 


\section{Sword and Plough}

The French invasion brought in its train a number of civilians. They were perhaps rather adventurers than of the stuff from which successful colonists are made. And the task before them was a stern one. The breaking of the soil was the first difficulty. It was covered with brushwood and dwarf palms, and its clearance involved much painful toil. There were no roads; even in the Metidja, close to Algiers, no means of communication but the mule paths; and no bridges. It is said that the journey to Blidah, which you may now cover in an hour or two, took four days. The country was most insecure; troops of bandits continually descended on the cultivated plains and robbed and murdered the colonists. Perhaps the greatest trouble of all was the prevalence of fever, especially in the Metidja. "The cemeteries," said a general, "are populated faster than the villages." Later the spread of cultivation diminished its virulence, and the use of quinine provided a remedy. It is said that absinthe was used by French soldiers as a febrifuge, ${ }^{1}$ and that they took back to their homes

1 See "Notes and Queries," February 25th and March 4th, I 911.

K

145 


\section{About Algeria}

a habit which has become so widespread. A treatise might be written on the influence of war on fashions in drink. The introduction of champagne into England is said to be due to the English officers who had discovered its virtues in Paris at the time of Bonaparte's downfall.

The Holy War of I839 had extinguished the feeble flicker of French colonization. The colonists were removed to Algiers for safety; and the Arabs pillaged and burnt their farms. The land reverted to barbarism. Bugeaud set himself to repair this damage, and to place colonization on a firmer basis. His idea was that the state should prepare the way by granting land under certain conditions of military service, that it should make careful selection among applicants for grants, and should provide funds for preliminary works,roads, wells and farm-buildings. This system was partially carried out, and has been justified by success. In spite of many troubles and setbacks, a constantly increasing area has been brought under cultivation. In 1854 the cultivation of cereals occupied about two million acres; in $186 \mathrm{I}$ it had risen to five 


\section{Sword and Plough}

millions; in 1885 to seven millions. Since that date the total has not sensibly increased, but methods have improved and the yield is greater. It is said that on the whole agriculture in Algeria is more progressive than in France. And as he traverses Algeria's interminable cornfields, the traveller may be disposed to render homage to the great soldier who, personally averse from conquest, drew the sword to establish peace, and strove to bring plenty in her train. 


\section{VI-TLEMÇEN THE HOLY}

Western Algeria-Sidi Bel Abbès-The Foreign Legion-A city of learning-Its inhabitants-The Mosque of Aboul Hassan-Mansoura-Its story-Sidi Bou Medine-Oran-Spanish immigrants.

"A city dreaming of her ancient pride

Amid the orchards on her mountain-side;

Do you sleep sound, O saint that shares her fame, While stranger horsemen through her portals ride?"

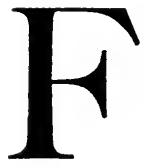

AR to the west, beyond Oran, and close to the frontiers of Morocco, lies a hill city, once the seat of empire and of learning, but now sunk to the condition of a provincial town. Yet Tlemçen has occupied so high a position in the Mohammedan world, and the reputation of its existing monuments is so widespread, that the enterprising traveller will desire to visit it. The distance from Algiers is great, some 800 miles there and back, and as there is little of interest on the road, a journey by motor-car is not inviting. It is perhaps better to make use of the excellent train service between Algiers and 


\section{Tlemçen the Holy}

Oran. If you leave Algiers at nine p.m., you may change about six a.m. at a junction a little short of Oran and reach Tlemçen about eleven. Or you may go on to Oran and hire a motor-car for the remaining I 10 miles, which it will cover faster than the train does. In any case it is a tiresome journey. The road and the rail alike rise through a series of great plains divided by rocky steps, and chiefly devoted to corngrowing. The country is very bare and very uninteresting. There are few trees. It is said to have been once well wooded, but, although the Arab will take care of a tree near his house or his mosque, he has no regard for trees in general. So countless generations of browsing goats have made an end of the woods. One cannot but think that more attention to reafforesting would meet with its reward.

Here, as elsewhere in Algeria, both in the plain and on the mountain side, the traveller will notice a number of square whitewashed buildings, surmounted by a cupola. They are known by the name of koubba, and are generally the tomb of a marabout or saint, and serve as objects of pilgrimage and much local veneration. 


\section{About Algeria}

At Sidi Bel Abbès, a town of 25,000 inhabitants, about half of whom are Spaniards, are the head-quarters of the famous Foreign Legion. The very name of this corps stirs memories of forlorn hopes and dare-devil enterprises. The inimitable Ouida, whose disregard of the grammatical niceties of her own and other tongues was a generation ago the delight of undergraduates; who could say of her high-born hero that he ignored the proud motto of his haughty race, Pro patria et rege, and acted on the principle, Pro ego; Ouida has pictured for us after her own fashion, in "Under Two Flags," the life of a foreign adventurer in the French service during the earlier days of the occupation. The picture, if imaginative in details, is full of life, and it is no doubt true that many broken men of gentle birth and upbringing found in the campaigns on the verge of the Sahara an outlet for energies for which civilization had no use. To-day the Legion is composed largely of Alsatians, Germans and Poles, and is celebrated for its band. But it is still to the fore when stern work is on foot. The situation of Sidi Bel Abbès renders it very convenient 


\section{Tlemçen the Holy}

in the event of trouble with Morocco, which is constantly recurring. The town and its environs are an agreeable exception to the surrounding country in being pleasantly wooded. The olive trees are most carefully pruned, all the centre branches being cut out, and the outer ones trained to form a cup. This system admits light and air to the fruit, and facilitates the gathering of the crop.

Within a few miles of Tlemçen the scenery becomes more bold. The train climbs on to and encircles a rugged mountain range, traverses a great ravine, down which roars a graceful cascade, and emerges from a short tunnel into the noise and hubbub of Tlemçen station. The high road takes another course. It skirts the base of the rocky hills, and boldly ascends direct to the town, offering pleasant views of its walls and minarets. This is the habit of roads and railroads in many lands; the road approaches boldly to a frontal attack; the railroad creeps in stealthily or remains diffidently outside. So does the traveller by rail too often miss the beauty of the incoming.

The Arab horsemen who in the seventh 


\section{About Algeria}

century of our era rode through North Africa and carried the crescent into Europe were the élite of the race. Not only did they and their sons and those to whom they taught their faith and language and made like unto themselves conquer kingdoms and found great cities, promote commerce and achieve enormous material prosperity, but under their rule were produced works of art worthy to be ranked with the best. It is perhaps lucky that progress in these respects was accompanied, as it is generally accompanied, by a decline in martial prowess, or Western Europe might to-day be tied fast in the chains of Koran, and the women of London and Paris be veiled as was Mahomet's wife. Among the greatest of Mohammedan cities from the eleventh century to the fifteenth Tlemçen stood high. It was peopled rather by Berbers than by Arabs of pure blood; but, at any rate, they spoke the Arab tongue, held the Arab faith and represented Arab culture at its highest excellence. In spite of the continual stress of war, it was enriched with noble buildings; it became a kind of university of Arab learning for North Africa; and it acquired the reputation and 
$F:+, \quad ;$ 


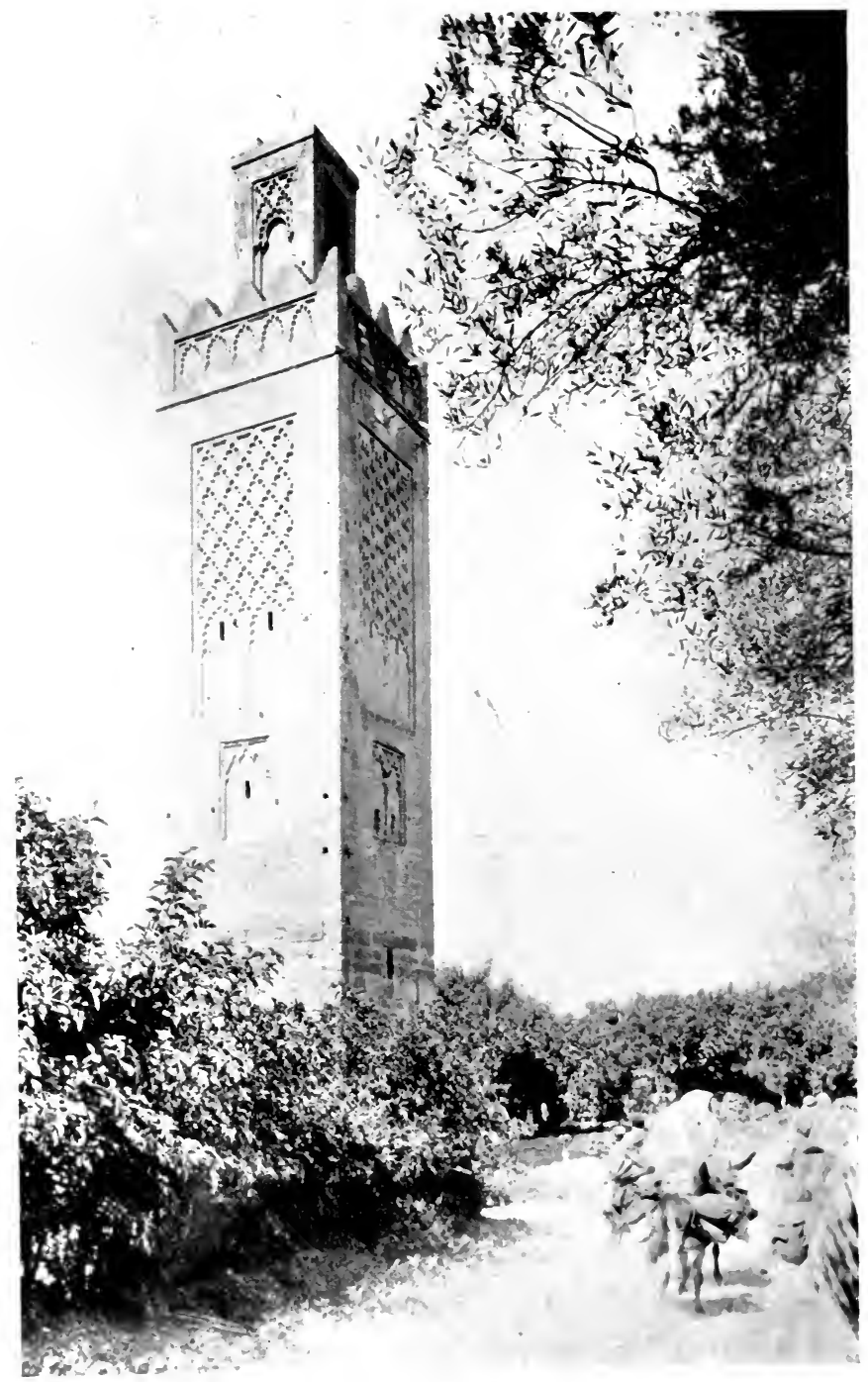

TLEMCEN : THE MINARET OF AGADIR 


\section{Tlemçen the Holy}

sanctity of a holy city from the selection of a neighbouring village as his last resting-place by a great Mohammedan saint.

At the period of its greatness Tlemçen was a large and populous city, containing 100,000 to 150,000 inhabitants. The enceinte constructed by the French encloses a much smaller area than the old walls, of which at least two series can be traced. The present town has about 30,000 inhabitants, for the most part Arab or Jew. It does a considerable trade, especially in olive oil ; but it has lost its position as the terminus of the caravan routes from the south, since the construction of the Saharan railways; it is cheaper to unload the caravans at the southern stations, and forward the goods to Oran by rail. Apart from the mosques the streets present little of interest. It is said that the French found the town almost in ruins; to-day it is a shabby fifth-rate French town. The inevitable boulevard has been constructed, and even where the old houses remain they are hidden behind a hideous modern front. The old palace of the bey has unhappily been turned into a barrack. The commercial value of antiquities as an attraction to tourists was 


\section{About Algeria}

not realized in time; it is hardly understood now. Tlemçen occupies an important strategic position, close to the Moroccan frontier, and is garrisoned by French troops. At the Hôtel de France, a somewhat ramshackle but not uncomfortable hostelry, with very obliging hosts, breakfast many officers of the garrison. The variety of uniform is great; not less great the variety of human types:-from the fair, and apparently frail, young exquisite, whose physique suggests rather the counting-house than the Sahara, to the grizzled veteran of many campaigns.

Yet the native inhabitants lend colour and interest to the mean streets. The Arabs of the better class wear a dark blue overcoat and hood, which shows off their proportions to great advantage. The women are very closely veiled, only exhibiting one eye. The children, especially the little girls not yet come to the age of veiling, are cheerful and pretty, their rosy cheeks bearing witness to the cold and bracing qualities of winter at this elevation. The Jewesses affect bright colours; and red is the colour of their mourning. An occasional stranger of fierce aspect and unusual dress 


\section{Tlemçen the Holy}

attracts your attention, and your guide murmurs " Marocain."

Some handicrafts survive in Tlemçen. The rubbishy trinkets dear to the Arab woman and the Christian tourist are laboriously turned out by Jews in the street of the goldsmiths. It is something to know that they are not made in Austria. Here and there you will catch a glimpse of an old Moor bending over a carpet loom. A good deal of leatherwork is done, and there is a brisk business in harness and saddlery. Tlemçen is no longer the terminus of the railway which runs to the frontier, but many frontiersmen come here to trade.

It is in vain to look in Tlemçen, as in other towns of Algeria, for the pure-bred Arab. Those who pass by the name are the result of a continual mixture with the indigenous races; they are Berberized Arabs or Arabized Berbers. But in many ways they compare favourably with their compatriots elsewhere. Tlemçen has preserved some of its traditions as a city of learning. Even to-day it contains a large number of educated Mussulmans and a few savants. You may see here, as often you may see in Cairo and the cities of the East, a trades- 


\section{About Algeria}

man seated in his little shop poring over an Arab text. In Algeria generally the standard of education among the natives is very low; only a small fraction of one per cent can read and write. The religion of the Tlemçen Arabs is naturally of a somewhat higher type than that of those who, knowing nothing of the law and the prophets, are content with the observance of fast days and a cult of saints mixed with all sorts of survivals of fetishism. The Arabs of Tlemçen are said to eschew fanaticism, as becomes men of learning, to regard those who are not of their faith less with hate than with pity, as having missed the true way of salvation; an attitude not uncommon in other lands. But their religion is incrusted with intense superstition. They live in constant terror of the influence of evil spirits, the Djinns, to which are attributed almost all human ills. A madman especially is said to be possessed of evil spirits, and he cannot be cured till they are cast out of him. This fear of evil spirits influences every action of their daily lives; it is the chief stimulus to devotion, for the $D$ jinns are kept not away save by prayer and fasting. 


\section{Themçen the Holy}

To-day the French are masters, but the Arab in his centuries of decadence has grown used to masters. They come, and pass, and he remains. It is the will of God. The French are lenient and just masters; they provide many material advantages,-security of property, means of communication, avenues of trade. God is good. But the Arab is always waiting for something to turn up; he will be sustained in almost fruitless labour on his barren plot in the hope of finding a treasure; he will waste his scant earnings in buying favourable horoscopes from his sorcerer; and if no treasure is unearthed, and no fortune arrives, he will put it all down to some flaw in the incantations. If all fails he has at any rate said his prayers five times a day and is sure of Paradise.

Yet in his heart he is ever looking for the advent of a Messiah, of a deus ex machinâ who shall overthrow the infidel, and restore the Arab to his own again. Let France be involved in difficulties elsewhere and the events of 1870 may repeat themselves.' The preaching of a holy war, the announcement that God's good time has come-such are the conditions to raise a wave of religious fanaticism strong 


\section{About Algeria}

enough to sweep away all considerations of prudence and self-interest. As long as his religion remains a compelling force, this is his danger and Europe's. In its present state Arab civilization, greatly fallen from its high condition of culture and learning in the twelfth and thirteenth centuries, may be compared with that of Europe in the centuries following the destruction of the Roman Empire. The Arab is now in the Dark Ages. The forms of his faith remain all-powerful, but the spirit is dead. A thousand years separate him from the Europe of to-day. Perhaps the best hope lies for him in a revival of his religion on the spiritual side ; from which may spring in turn a germ of those ideals of citizenship, toleration and benevolence which are the basis of our civilization; ideals flowing from the teachings of Christianity, but not confined in their influence to the orthodox of any section of Christendom.

A very cursory view of Tlemçen suggests that those enthusiastic writers who have described it as the equal, or almost the equal, of Granada are somewhat extravagant in their praise. It occupies indeed a fine situation, and it looks 158 


\section{Tlemçen the Holy}

down from its height of 2500 feet over a rolling country of hill and vale to the sea thirty miles away. But it has none of Granada's grandeur and it lacks the noble background of the Sierra Nevada. It has no great building like the Alhambra, although its mosques contain magnificent work, which is unsurpassed and perhaps unequalled elsewhere. Excessive praise which raises expectations destined to be disappointed is to be deplored. Tlemçen has enough of beauty and interest to stand on its own merits. In one respect it has an advantage over the Moorish cities of Spain. It is indeed held by an alien race, but its mosques are still for the most part put to the purpose for which they were built, and the worshippers are the present representatives of those who built them.

The Great Mosque, the most notable building within the walls, was not built all at one time, but grew, like a Gothic cathedral, under the hands of different monarchs and dynasties. These dynasties of Tlemçen were continually changing; their outlandish names cumber the guide-books, but they have less interest for us than the vicissitudes of the Guelphs and Ghibellines. The first stone of the mosque was 


\section{About Algeria}

laid in the year 530 (you must add 605 to bring it to the Christian era), as a contemporary inscription obligingly records. The minaret was built by Yar'morasen, the great Berber monarch who raised Tlemçen to its pitch of power in the thirteenth century; and in the fourteenth various auxiliary buildings, including a hospital for the aged and incurable, were added. The interior of the mosque is impressive, with its forest of pillars-there are seventy-two in all-and its dim religious light. The mihrab, the holy of holies, the shrine which looks towards Mecca, is finely decorated with leaves of acanthus and Arabic inscriptions. The large court is charming; it is surrounded by arcades, and two basins of running water provide for the ablutions of the faithful. The material of the whole was originally onyx, and much remains. It is truly a noble building, and it has escaped any serious restoration.

Unhappily the same cannot be said of the neighbouring mosque, known as the Mosque of Aboul Hassan, an eminent lawyer and saint; a combination which seems unusual. On this delightful little building the hand of the restorer has lain heavy. He has seen fit to 


\section{Tlemçen the Holy}

plaster it with modern tiles, suggestive of the bath-room; and in order to throw more light into the building, which is now used as a museum, has made several openings in the walls. It is poor comfort to find in a distant land that we English have no monopoly of ecclesiastical vulgarity; even our church restorers could hardly have done worse than this. It is not easy to formulate the ethics of restoration; the right course can only result from intelligent and instructed effort,--but this may be said of almost everything. The ignorance and indiscretion of those who add poor modern ornament to a grand old building passes understanding. It happens that this little mosque, charming otherwise within and without, enshrines a masterpiece, its mihrab. The mosque was erected in A.D. 1298, according to an inscription on one of its arches, and presumably the interior decoration is of the same date. The dates of the world's few masterpieces are important. The decoration of the mihrab is executed in plaster. I am not competent to describe its details; they follow the conventional scheme of leaves and scrolls, but with quite unusual refinement. This mihrab 


\section{About Algeria}

has been highly praised; but no praise can be too high for it. It has been described as the finest example of Mohammedan art in existence; it is very likely that it is. An eye that has enjoyed any training will see at a glance that it is on a par with the greatest decorative works of man; it exhibits all the characteristics of the finest periods, especially the combination of exuberant fancy with dominating restraint. Its exquisite delicacy and its small size give emphasis to its unique distinction. I cannot refrain from quoting a French writer who fitly appreciates its qualities: "Cette décoration est le comble de la richesse et du goût ornamental. Elle réunit en effet les qualités les plus diverses; homogénéité de l'ensemble, variété infinie du détail, netteté et fantaisie, largeur et minutie dans l'exécution. Elle est empreinte d'une sorte d'atticisme oriental, d'une beauté atteinte sans efforts et naturellement. Capter la lumière sans grands reliefs, l'emprisonner dans les réticules d'une ténuité extrême, la forcer de se jouer dans ses méandres idéalement fins, donner à des murailles toutes unies un vêtement de dentelles; un encadrement de rubans historiés qui les aggrandit et 


\section{Tlemçen the Holy}

les rend pour ainsi dire immatérielles; entraîner le regard et l'éblouir par la complication, le rassurer par l'ordre et la paix, voilà le problème que d'obscurs ouvriers ont résolu à la fin du treizième siècle de notre ère." 1

Another pleasant little mosque, that of Sidi-el-Haloui, lies outside the walls in a squalid native suburb, which is nevertheless a better frame for it than the banal French houses of the town itself. It has a very fine portal and a pleasant court. It commemorates a very extraordinary character, who from being Cadi of Seville became in disguise a confectioner at Tlemçen. He was put to death apparently for spreading seditious doctrines, but his ghost having given some trouble he was canonized.

It is said that Tlemçen was built on the site of a Roman camp called Pomaria. The name happily expresses the abundance of orchards by which it is surrounded. In February only a few almond trees are in blossom, but the ground is beginning to put forth its wild flowers. A diminutive iris is everywhere, and gives a blue tinge to the wayside, as the blue-

1 Ary Renan, "Paysages historiques." 


\section{About Algeria}

bells to an English copse. In April, when the trees are bursting into leaf and the whole country-side is full of flowers, Tlemçen must be set in a very bower of delight. And it is in the environs that the most interesting, picturesque and romantic of its antiquities are to be found.

Just outside the Fez gate of the city lies a great artificial basin or reservoir, now dry, which is said to have been constructed by a king of the fourteenth century to give his wife the pleasure of witnessing miniature seafights. It is related that Barbarossa drowned in it the descendants of the ancient kings whom he found at Tlemçen, and watched their struggles with glee. A short distance further on is an arch, ruthlessly restored, which was part of the wall of circumvallation built around Tlemçen by Abou Yakoub, Sultan of Fez, who besieged it from I 299 to I307 A.D. A little further on are the extremely picturesque walls of Mansoura, the city which during the siege he built for himself. The story of this siege and of the building of Mansoura is very curious. It is told at length by the Arab chroniclers. Perhaps the 


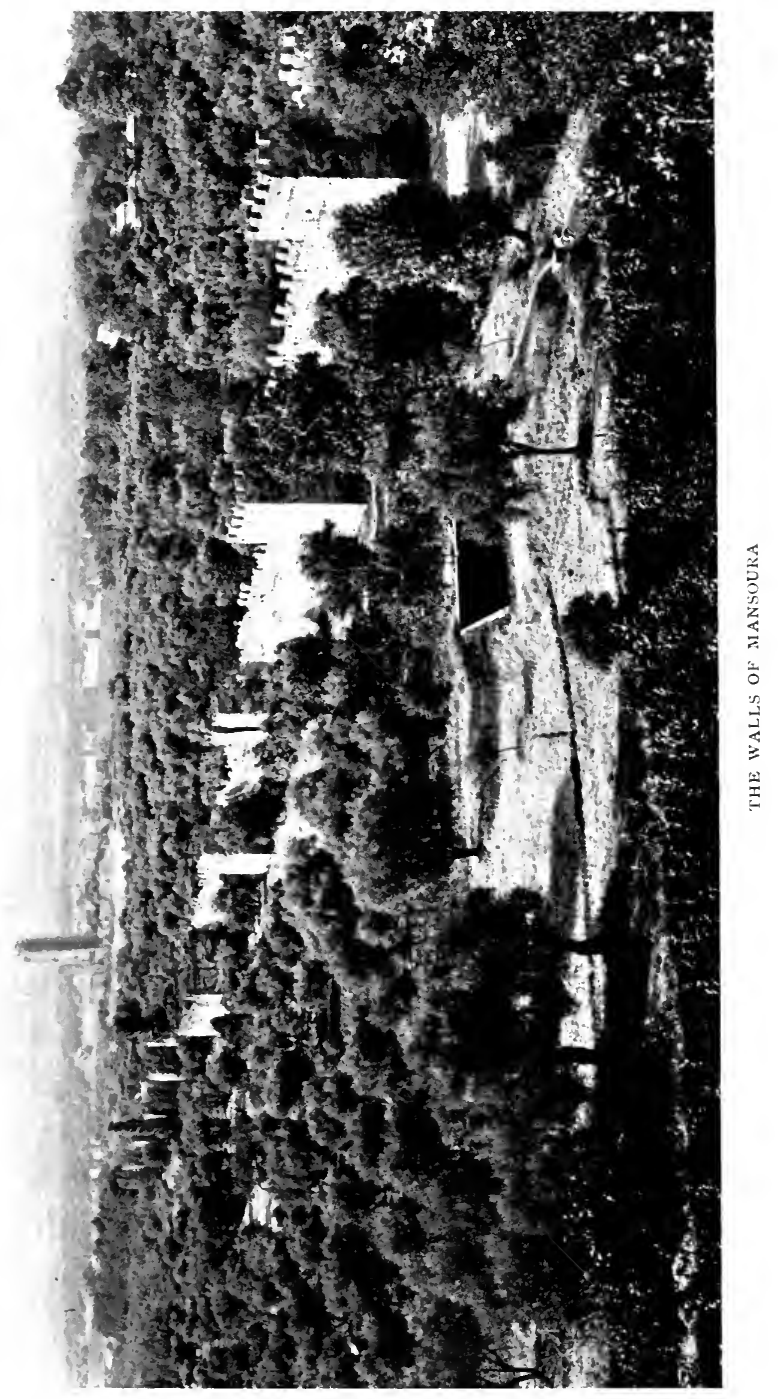





\section{Tlemçen the Holy}

following abbreviation of their account will suffice.

And it came to pass in the reign of Othman, King of Tlemçen, that Abou Yakoub, King of Fez, gathered all his host together and went up and besieged Tlemçen seven years. And he built towers against it round about, and a wall so strong that the people said one to another that not even a spirit might pass through from within to without the city. And forasmuch as the city was not yielded unto him, but held out against him for seven years, did Yakoub the King of Fez set up for himself in the camping-place of his host a great palace wherein to dwell; and all about the camp he built a great wall with towers so that he made of it a fenced city, and within he built palaces for his wise men and his mighty men of war, and great houses, and fair gardens wherein were streams of water running continually. And he caused to be set apart also a dwelling-place wherein might be tended they that were sick, for that he was moved to compassion of their sickness; and to the strangers he gave inns to lodge therein. Moreover he built a mighty temple with a tower of exceeding height so 


\section{About Algeria}

that it might be seen in all the land; and he bowed himself therein before his God upon the seventh day. And many merchants of that country did gather themselves together in the town which Yakoub the King had builded, and the kings of far countries sent unto him ambassadors with gifts. And Yakoub called the town which he had builded Mansoura, which being interpreted signifieth "The Victorious."

And in the fifth year of the siege Othman, King of Tlemçen, was gathered to his fathers, and his son Abou-Zeiyan reigned in his stead. And the people of Tlemçen were in sore distress for that no food could be brought into the city by reason of the wall which Yakoub the King had builded round about it. So when the siege had continued for the space of three years more, the King Abou-Zeiyan and Abou-Hammon, the King's brother, called unto them the captain to whom was given charge over the stores of food in the city and said unto him, "How long may we feed the people with the food which is left ?" And he answered, "For the space of three days." And there came in unto the King Dâd, the 


\section{Tlemçen the Holy}

servant of the Queen-Mother. And Dâd said unto the King, "Let not, I pray you, the princesses and the women of your house fall into the hands of our enemies, but rather let them be put to death." And Abou-Hammon, the King's brother, answered, "What Dâd hath spoken is good counsel." But the King said, "Nay, we have yet three days, perchance God will come to our aid. And if it be so that we must deliver up the city, then we will cause the Jews and the Christians to kill the princesses and the women of our house, and we ourselves will sally forth and fall upon the host of our enemies." And the King wept. But lo, while they yet spake, a man of the host of Yakoub the King lifted his hand against him and smote him so that he died. And Yakoub the King's brethren and his sons, and his son's sons strove among themselves who should be king in his stead. And the son of one of his sons, who was called Abou-Thabet, obtained the mastery over them. And Abou-Thabet made peace with Abou-Zeiyan, King of Tlemçen, and led back his host to the country of Fez, whence it came. And Tlemçen had peace thirty-three years. 


\section{About Algeria}

So runs the tale of the Arab chroniclers, and the walls and towers of Mansoura stand to-day in witness that they lied not. Their entrancing story is full of the elements of Oriental romance:-the fairy city springing into being almost in a night; the fearful proposal of the aged servant that the women should be killed; the long years of the siege reaching their tremendous climax in the assassination of the aggressor at the very moment when the besieged were preparing to sell their lives dearly; the struggle of the dead Sultan's brothers and sons and grandsons for the succession. Such a struggle is a commonplace of Mohammedan politics; we have seen it in our own day in Afghanistan and Morocco; we may see it in Turkey to-morrow. It may plunge the country where it occurs in civil war, but in a South American republic even a change of party groupings will do that. As a system it can claim some merit in that it tends to place on the throne the strongest or the most astute member of the royal house.

Of the dream city of Mansoura nothing remains but the square of the ramparts enclosing a space of 250 acres, and the great 


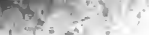

$x_{j}=$. 


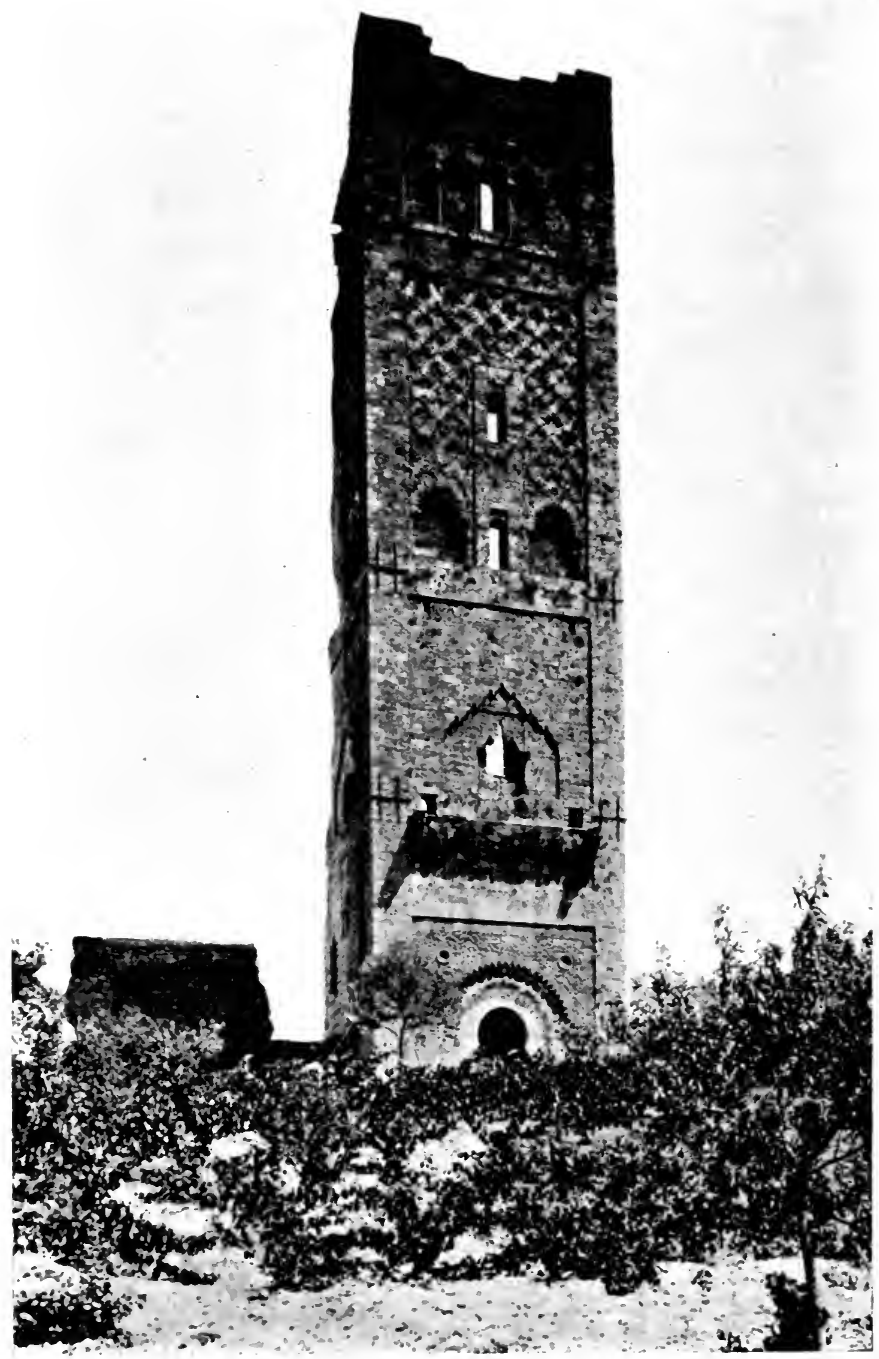

THE TOWER OF MANSOLRA 


\section{Tlemçen the Holy}

minaret of the mosque. The city itself was destroyed by the Tlemçenites after the departure of the Moroccan army. The walls are about 40 feet high, and the towers 120 feet apart. They are all built of concrete, and though broken in places, are marvellously preserved. Weathered to a delightful tint of rich brown, they contrast admirably with the sombre monotony of the olive trees; and they lend to the pleasant mountain landscape a unique spice of romance.

The minaret, of which the inner portion has fallen while the outer remains standing, is a very noble tower, and the finest architectural work of Moorish times in Algeria; it would be difficult to match it anywhere. It stands about I 30 feet high, and is built of hewn stone. Its front was decorated with coloured tiles, of which many are left. Legends have gathered round it. It is said that in his haste Abou Yakoub employed not only Mohammedan but Jewish and Christian masons, and that it is the work of the infidels which has fallen, while that of the faithful survives. It seems to have been also a starting-place for an early experiment in flying. A certain Jew imprisoned 


\section{About Algeria}

therein made himself wings, and setting forth on the occasion of a great service, fell lamentably at a spot called to this day "Le Col du Juif." Such is the fate of pioneers.

The status of Tlemçen as a holy city, which draws to itself pilgrims not only from the countries of North Africa, but from the very confines of the world of Islam, rests on its connection with the saint Sidi Bou Medine. It has long ceased to be the capital of an African empire; it is no more a university of Mohammedan learning; its very name is almost unknown to the present generation of European men; but in the eyes of the faithful it is ever honoured. It is a little difficult for an unbeliever to comprehend what constitutes peculiar eminence in a Mohammedan saint, and there is nothing in the recorded life of Bou Medine to throw light on the question. It is related that he was born at Seville in A.D. 1126 , that he was an ascetic and a mystic, that he travelled through various Mediterranean countries performing miracles, preaching the vanity of earthly things, and emphasizing the beneficence of God and the authority of his prophet. Accused of heresy by the doctors of 


\section{Tlemçen the Holy}

Tlemçen, he was summoned thither by the reigning monarch from Bougie, then within the boundaries of the Tlemçenian Empire. His failing strength sustained him almost to the city's gates, when, looking up at the little village of El-Eubbad, with its hanging woods beneath the rugged cliff, and owning at last the charm of the world he had so fiercely disdained, he breathed a wish to be buried in that lovely spot, and expired. And there for seven centuries he has lain, and you may stand beside his tomb, which is decked in the tinsel pomp of Mohammedan finery and surrounded by the offerings of the faithful. It is approached from a little court-yard, in which is an ancient alabaster well-head curiously worn by the chain which draws the bucket.

The mosque which adjoins the tomb was raised shortly after the saint's death. It is of no great size, but both structurally and decoratively it possesses a charm which is unique. The high portal is a blaze of tiles in the finest style; tiles said to be partly of Moroccan, partly of Spanish, origin; and the doors of cedar wood, covered with bronze, ornamented with a design of arabesque interlacement, are 


\section{About Algeria}

incomparably beautiful. - It has been said that they are to Moorish art what the doors of Ghiberti are to Italian; but in their decorative flatness-a quality which becomes doorsthey have a distinction which is their own. In the whole realm of Moorish decoration I have seen nothing more charming. The mosque itself does not belie the promise of its entrance. It follows the usual plan, but on a very high level. Its plaster decorations, if somewhat less fine than those of the mihrab of Bel Hassan, are in the best style. The whole building is instinct with the charm of unassailable fitness, and fills the mind with an ineffaceable impress of beauty.

From these heights-mountainous and æsthetic-it will probably be the lot of the traveller to descend by easy stages to the town of Oran, which, as a commercial port, is the rival of Algiers. Unless he desires to do deal in olive oil or esparto grass, or intends to become a shipper of fine clarets and burgundies, it will not detain him long. Yet it is pleasant for an hour or two to sit before one of its brilliant cafés and survey the palpitating life of the streets. Oran is more than half 

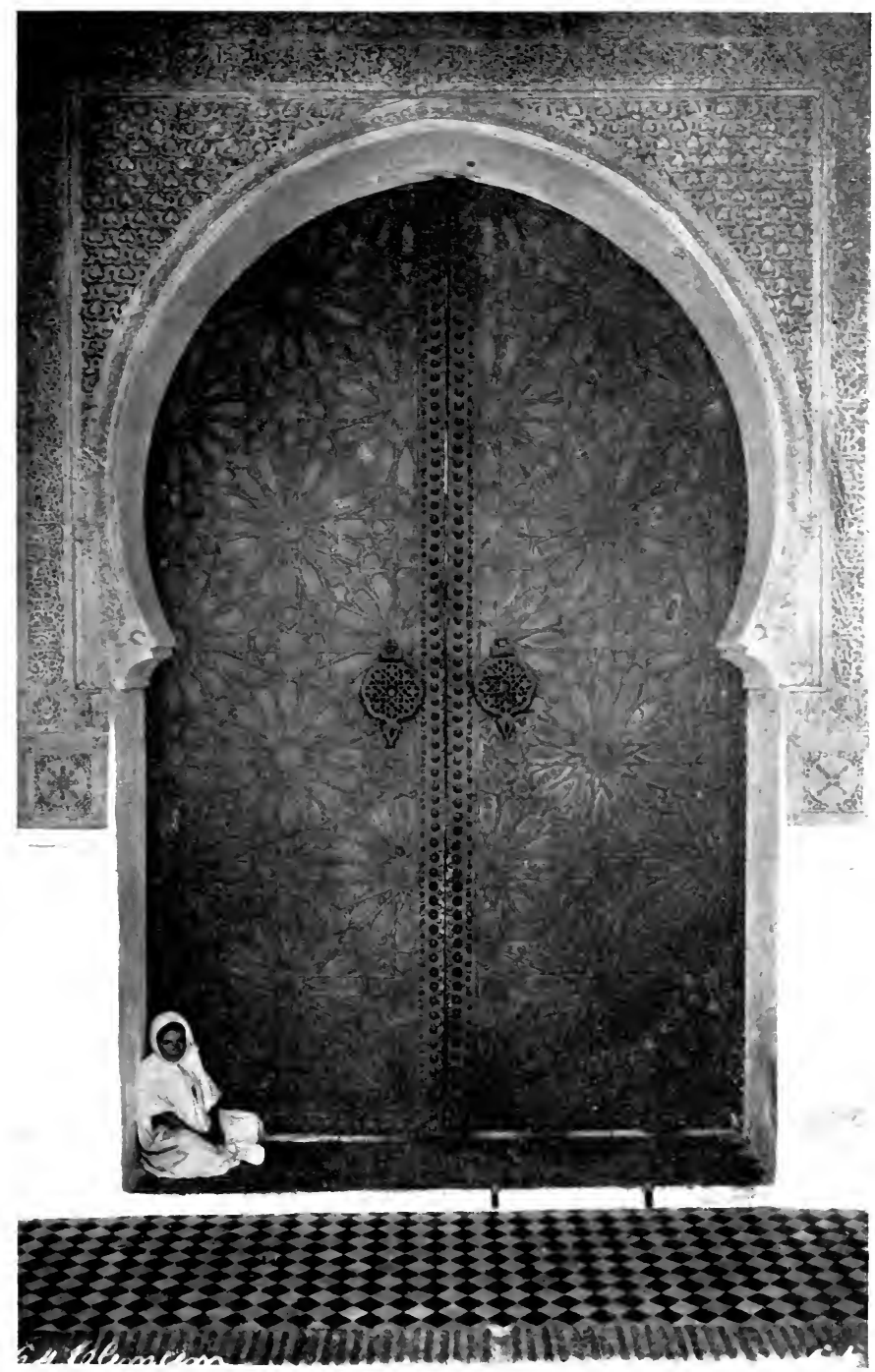

SIDI BOU MEDINE: THE BRONZE DOORS 


\section{Tlemçen the Holy}

Spanish; it is historically almost wholly Spanish. To-day, if you inquire of a stranger your way in French he will very likely reply by asking if you have the Spanish, and if you have it not you must try again. But the Spaniards, great builders in Europe and beyond the seas, built little but fortifications on the African shore. Oran is frankly modern and European in aspect; the most Oriental-looking building is the railway-station. The French have built fortifications too; a picturesque fort crowns a hill to the west, a thousand feet above the town; and there is much show of strength below. And there is an important garrison. Brilliant groups of officers frequent a café at the corner of the Place d'Armes, and get through a most unconscionable amount of hand-shaking. I notice that one of them, apparently a Siamese, who yet sips his sirop as to the manner born, is the object of much attention. With the mass of the cafés frequenters the soldiers appear to have no acquaintance. These men of business are Frenchmen in manner and speech, but there is a prevalence of that Levantine air which pervades the Mediterranean ports;-not quite 


\section{About Algeria}

Greek, not quite Jew, and yet not wholly European.

If there is one institution more characteristically French than another, it is the Café. And, further, it is an institution which no other people, unless it speaks French, as do the Belgians, can reproduce. France has set the mode to Europe for centuries, but it has reserved the café. The other Latin nations are content with bastard imitations; the northern peoples frankly own their failure. Who can conceive a café in Hull or Aberdeen ? Not more incongruous was the attempted battle of flowers in a Lancashire town,- the mayor had visited Monte Carlo,-which ended in the choockin' o' loomps o' coal and the military being called out. It is not a matter of climate; Brighton and Worthing have climatic advantages over Boulogne and Dieppe. It is rather a matter of character. The café depends for its existence on French moderation and French civility, in the widest sense. The German in his beer-garden piles empty glass on empty glass; the Englishman lolls at his reeking bar; only the Frenchman can be trusted to sit at his will at his little marble 


\section{Tlemçen the Holy}

table, and contemplate his little drinks, and play his little games. He does not exceed, he does not quarrel; if he did either, the café were impossible. So is he a free man, while we for our sins must submit to stringent regulations of police.

Oran's fine old Spanish fort and the ancient walls still speak of the Spanish dominion. It was a penal station to which convicts were sent, and the governors were in the habit of putting their labour to some useful purpose. An inscription records that the citadel was built at no cost to his Catholic Majesty but for the timber and scaffolding. After repeated struggles the town was surrendered to the Turks in 1791, a very convenient arrangement, as things turned out, for the French, who occupied it forty years later. And they have made it what it is. Yet among the lower orders the Spanish element is perhaps still preponderant. To paraphrase the words of a French writer "- "the peasants of Valencia and Murcia have only a few hours of sea to cross, and a bad season at home brings them in hundreds. If they find no work in and around

1 P. Bourde. 


\section{About Algeria}

Oran as gardeners they betake themselves to the country, and become field-labourers, or harvesters of esparto grass. Sober and industrious, they are especially fitted to the conditions of cultivation in Algeria, which without irrigation is unproductive. They have in their veins the blood of those Moors who taught Spain to husband her waters. Oran is for them almost their own country, the two sides of the Mediterranean have identical characteristics; and in the smallest villages of the province they find themselves at home among their own people."

It is interesting to recall in this connection that the increase of emigration from Spain generally is becoming a very serious matter. It reaches the annual average of 200,000 persons, or considerably more than one per cent of the total population. The late Government in 1907 dealt with the matter, and appointed a Conseil Supérieur de l'Emigration, which took the exceedingly futile course of endeavouring to check it by police interference with persons arriving at a port to emigrate, the arrest of emigration agents, and complicated regulations affecting steamship companies, 


\section{Tlemçen the Holy}

which it has been found impossible to carry out. The chief effect has been to conceal a certain amount of emigration, which doubtless exceeds the official figures. The present radical Government, pledged to reform in every department of the national life, is attempting to check unemployment and emigration by a scheme of extensive public works. Meantime under French institutions, Spaniards are living contentedly and prosperously in a country marked out by nature for their occupation, which they were never able to secure for themselves. 


\section{VII-THE CITY OF PRECIPICES}

Road and rail to the eastward-Constantine-Its remarkable site-Its chequered history-French Conquest-Roman remains-Fronto-

The Mairie-The road northward-The Aures.

" A towered citadel, a pendant rock."

Antony and Cleopatra.

T $\mathrm{F}$ the traveller intends to journey from Algeria into Tunisia, he will do well to visit Khabylia before he starts further east; if not he may proceed first to Constantine, and motor through the mountain districts from Sétif on his return. For the greater part of the way the great trunk road and the railway from Algiers to Constantine take a similar course; but towards the end they diverge, Constantine being situate north of the main line from Algiers to Tunis, at a distance of twenty miles from the junction of El-Guerrah, while the road passes through the city. Hence it comes that the distance by road is 434 kilometres, by rail 464 . There are not 


\section{The City of Precipices}

many convenient stopping-places, perhaps Sétif is the best.

By train you may make the journey either by night or by day; the latter is preferable, as much of the scenery is beautiful and interesting. Leaving Algiers the line crosses the Metidja, the great plain which encircles the Sabel, the rocky promontory on which Algiers stands, stretching on either side of it from sea to sea. At Ménerville it begins to ascend, and shortly enters the Gorge of the Isser. The country here is very picturesque; the river roars through a narrow cleft in the rocks, Khabyle villages are perched on isolated points, and ruddy mountains stand bare against the deep blue sky. Palestro, a little further on, was the scene of a terrible and treacherous massacre in the Khabyle insurrection of 1871 . The European residents, numbering over a hundred, were attacked in their residences. After a desperate resistance about half surrendered on terms, but were immediately killed. The remainder held out longer but about forty survivors, including thirty-two women and children, were ultimately captured and kept prisoners till the revolt was crushed. 


\section{About Algeria}

Further on the line runs under the southern slope of the snowy Djurjura range, which is such a prominent object from Algiers. The view of the mountains is very fine. All the time the line is ascending, as it continues to do as far as Sétif, 200 miles from Algiers, and 3573 feet above the sea. Here we are in the centre of a vast corn-growing district, once the granary of Rome. The country-side is full of Roman remains, of towns and countryhouses and farms. At this altitude the climate, if hotter in summer, resembles that of Central France. The landscape is very bare,-a vast sea of corn, without a tree to break its monotony. To the east of Sétif the plain begins to slope downwards; the railway diverges to the south, but the road enters the valley of the Roumel, the river which forms the moat of the rock-girt city of Constantine.

Constantine occupies one of those positions of natural strength which from the earliest times man has seized upon as a habitation secure from the attack of his fellow-man. It is too much to suppose that its beauty had any force in such a selection. Yet it combines picturesqueness and grandeur with strength to 180 


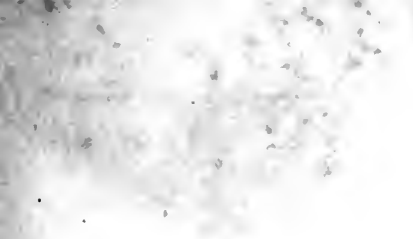




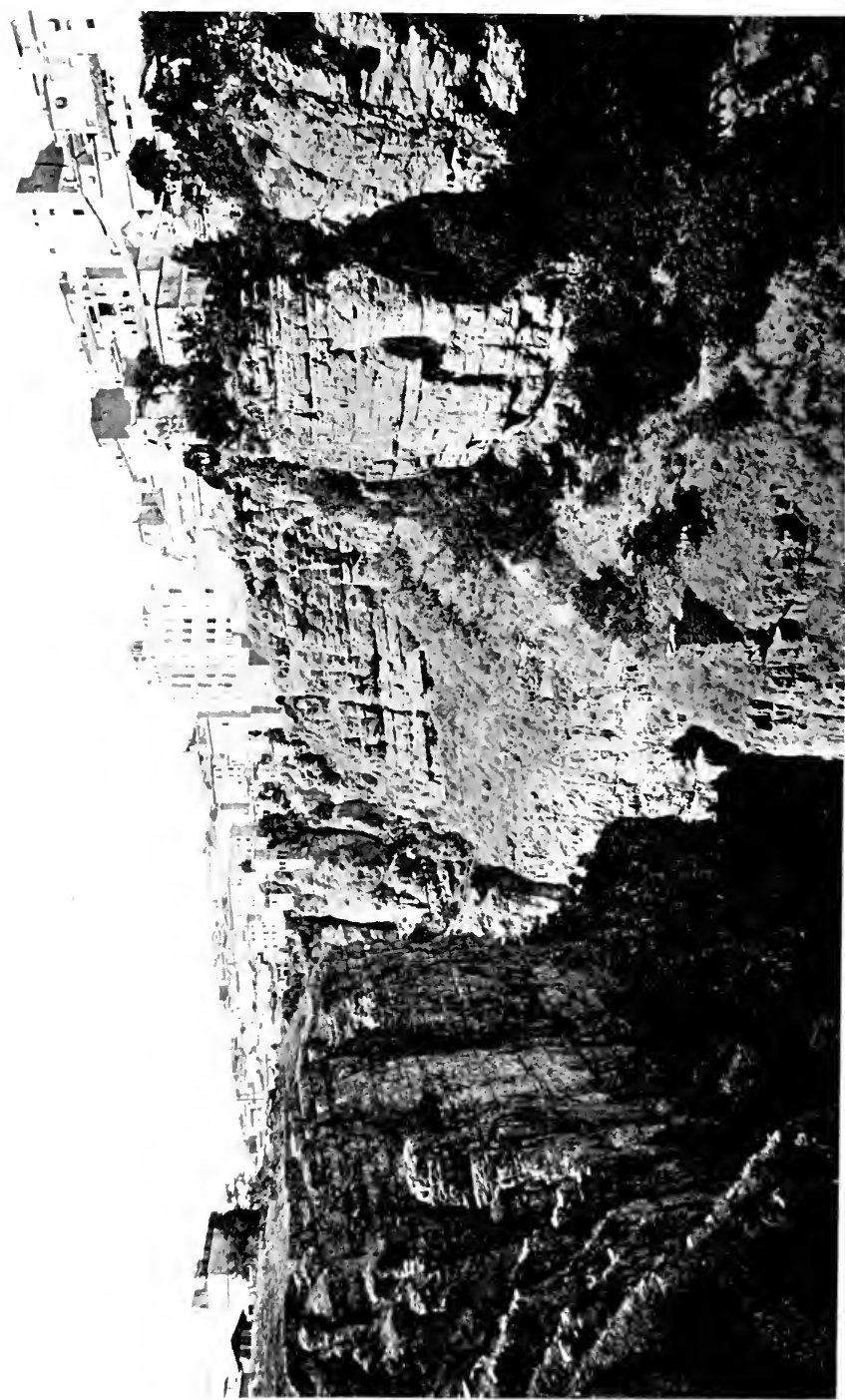




\section{The City of Precipices}

a remarkable degree. A circular chasm or ravine, nearly 1000 feet deep, and sometimes not more than 200 feet wide, creates a plateau which is in fact a peninsula of rock, only united to the mainland by an isthmus on the west side. Through the abyss roars the river Roumel. The plateau is not circular, but in the form of an irregular square, with sharp angles,-a formation which greatly increases the majesty of its effect. The length of the sides averages about 1000 yards. In this confined space are crowded together the habitations of men,- the European quarter, the Arab quarter, and the Jewish quarter,-the public buildings incident to an important town, and considerable barracks and fortifications.

"Le fantastique Roumel, fleuve d'une poème qu'on croirait rêvé par Dante, fleuve d'enfer coulant au fond d'un abîme rouge comme si les flammes éternelles l'avaient brûlé. Il fait un île de sa ville, ce fleuve jaloux et surprenant; ill'entoure d'un gouffre terrible et tortueux, aux rocs éclatants et bizarres, aux murailles droites et dentelées." 1

A great part of the attraction of a city

1 Guy de Maupassant, "Au Soleil," I904. 


\section{About Algeria}

occupying such a site lies in its suggestion of romance. It calls up visions of furious siege and desperate defence, of attempts to scale impossible cliffs, of hand-to-hand encounter at the only gate. And the actual records of Constantine almost surpass the possibilities of romantic imagination. It can lay no claim to that happiness which comes from having no history. Alike from its commanding situation and the richness of its surrounding lands it has been marked out by nature to be an incentive to ambition. It has known many masters. It is said to have stood eighty sieges. Its apparent impregnability has but invited attack. It has been a necessary mainstay to the support of every power which has aspired to the lordship of Barbary. It has seldom been a fitting residence for those who desired a quiet life.

Under its early name of Cirta it was the capital of that dynasty of Numidian kings who fought first for Rome against Carthage, and then for themselves against Rome. It became in due course a Roman colony. In the fourth century it was ruined in the wars which rent the empire, and re-arose as Con- 


\section{The City of Precipices}

stantine. Re-naming, with a spice of subservience, was a passion of the time; even so to-day do the Piazza Umberto and Boulevard Carnot obliterate ancient landmarks. The frenzied quarrels of Christians and Christian heretics, which tore Africa to shreds, raged within its walls, but spared its buildings. Genseric the Vandal, and the Byzantine Belisarius were its lords in turn. Then came the Arab. Darkness broods over its history for centuries, broken only by lightning flashes of capture and recapture. The Barbarossa brothers recognized the truth that he who would rule in Algeria must hold Constantine. They and their successors conquered it, and lost it, and conquered it again. Its Beys were nominally subservient to the Deys of Algiers, but Constantine breeds insurrection, and maintained its traditions during the Turkish domination. Even at the beginning of the nineteenth century, during a period of thirty years, twenty Beys succumbed to poison, the bow-string, or the sword.

" Here Sultan after Sultan with his Pomp Abode his Hour or two and went his way." 


\section{About Algeria}

At the time of the French invasion its Bey, Hadj-Ahmed, was in insurrection against the Dey, but made common cause against the unbeliever. After the capitulation of Algiers he retired to Constantine and declared himself independent, and took the title of Pasha, with the countenance of the Porte. His minister, Ben-Aissa, a humble Khabyle in origin, and a blacksmith by trade, was a man of marked ability. The two created an army of Khabyles, and breathed defiance to the French. In 1836 Marshal Clauzel advanced against Constantine with 8000 men. Among them was a young captain of the staff, afterwards Marshal Macmahon. Clauzel attempted an assault by the bridge of El Kantara, but was repulsed with great loss, and hardly retreated with his broken army to Bône. France could not brook such a defeat. Another army of 10,000 men was despatched under General Damrémont and arrived before the city on October 6th, 1837. To his summons to surrender came the response, "He who will be master of Constantine must cut the throat of the last of its defenders." A few days later the General in command and General Perrégaux were killed 


\section{The City of Precipices}

side by side in the course of siege operations, and General Valée assumed the leadership. On the rith he took the city by assault. Numbers of the besieged endeavoured to escape by ropes into the ravine, but the ropes breaking they perished. Hadj-Ahmed evaded capture, and for eleven years maintained himself in the Aurès mountains. In 1848 he surrendered, and died two years later. For seventy years an unwonted peace has brooded over the heights of Constantine; but who shall say that the end is yet?

As usual, the French have destroyed most of the remains of the Roman city; the exigencies of space are here a better excuse than exists elsewhere. But the antiquary may still ferret out endless evidences of the ancient town. The ordinary traveller may amuse himself by strolling through the Arab quarter; he may perambulate the gorge by the Chemin des Touristes; he may cross the bridge and ascend the opposing height to view in its majesty this unique city of precipices. With a map and moderate intelligence he will need no guide; but he will be pestered by the attentions of guides, responsible and irre- 


\section{About Algeria}

sponsible. They throng the door of his hotel, they mark his goings-out and his comings-in; and unless he succumbs to paying blackmail to one of the fraternity, they will strive to make his life a burden to him. Yet is there a certain fierce pleasure in denying them. The guide who haunts the hotel door is generally one of the least estimable of men, especially in Oriental countries. If you are weak, he will prey on your weakness; if you are vicious, he will reap his reward in ministering to your vices. He does not shrink from suggestion, and he seems to know no shame. He sometimes, when not guiding, fills a menial office in the hotel; one can hardly suppress a smile at the idea of the epicurean having his pleasures chosen for him by the Boots. To the credit of Algiers it may be said that one is there little troubled by these vermin; but Constantine has something to learn.

The Roman city of Cirta must have presented a marvellously beautiful spectacle. Classical architecture perhaps looks its noblest in buildings which crown a height. The temples of Cirta were of course not individually comparable with those which adorned 


\section{The City of Precipices}

the Acropolis of Athens, or the line of cliffs at Girgenti; but from a general scenic point of view the effect would be similar and on a greater scale. If the present city, which (like the belfry of Christchurch) has no architectural merits, looks so impressive at a little distance, the ancient city with its marble columns and triumphal arches must have been grand beyond our powers of realization. We know from the ruins at Timgad what a Roman city in Africa was like, and Thamagudi was a provincial town of no great mark, while Cirta was the capital. Its remains are to be seen everywhere, especially by the iron bridge of El Kantara, which replaces the ancient Roman bridge, a very remarkable structure which stood until 1857 , when two of its arches fell. It was designed to carry an aqueduct, and a roadway, which was supported on a double series of arches, stood 400 feet above the level of the river. It excited the wonder and admiration of all travellers. Shaw saw it in 1740. He says it was "indeed a masterpiece of its kind, the gallery and the columns of the arches being adorned with cornices and festoons, ox-heads and garlands. The keystones also of 


\section{About Algeria}

the arches are charged with Caducei and other figures."

The gorge contains many other Roman remains. Numerous inscriptions, statues and ornaments have been removed, and are collected in a garden near the Place de la Brèche. In this neighbourhood was found a delightful epitaph of one Praecilius, a silversmith, written in very inaccurate and unclassical Latin, which may be thus translated :-

"Here I, silent myself, in verse describe my life. I have filled an honourable career in prosperous times; Praecilius my name, a householder of Cirta and a silversmith by trade; a man of acknowledged probity and unvarying truthfulness. I have been friendly to all men, and whom has my charity failed ? Laughter and good cheer I ever enjoyed with my chosen friends. Life was not the same to me after the death of my virtuous wife Valeria ; I found my happiness in holy wedlock. I have celebrated in honourable fashion a hundred happy birthdays. But there has come at last the day when I must shuffle off this mortal coil. The inscription you read while yet living I have prepared against my death. Let it be as 


\section{The City of Precipices}

Fortune wills; never has she deserted me. Follow my example. Here I await you. Come!"

To one illustrious citizen Cirta gave birth, Fronto the orator, friend of the Emperor Antoninus Pius, and tutor of his heir, Marcus Aurelius. Some of the correspondence of the master and his pupil has been preserved. It abounds in intimate and homely touches. The prince went out hunting one morning, and on his return wrote: "I betook myself to my books. I took off my boots and my clothes, and went to bed for two hours. I read two orations of Cato. I think I have caught cold, perhaps because I walked in sandals this morning. So I will pour oil on my head and go to sleep. Farewell, my dearest and sweetest master, whom I love better than Rome itself." When Marcus Aurelius succeeded to his imperial throne he offered his old tutor the proconsulship of Asia, one of the greatest positions in the Empire, but Fronto, who perhaps preferred to remain in his native Africa, refused the office on the ground of ill-health. Nothing has been discovered at Cirta bearing on Fronto's connection with the city, but an 


\section{About Algeria}

inscription built into a house at Guelma, the ancient Kalama, records his official appointment as patron of that town.

The Arab quarter, which is gradually being squeezed out of existence, is quite different in character from that of Algiers. Its lanes are equally tortuous and narrow, and even more dirty, but it is more full of life and more actual. In Algiers most of the native shops are in modern, Frenchified streets; here they line the ancient alleys. Merchants sit in the serene Eastern fashion beside their stores of merchandise; artisans ply their little trades in a very confined space. More than half the population appears to be occupied in making shoes. The general confusion is increased by the constant passage of animals, horses, mules, donkeys and camels. It is a little bit of an old world, and being in close contact, yet hopelessly out of touch, with the dominant world of the day, its hours are numbered. The march of improvement, especially when cribbed and confined as by the cliffs of Constantine, brooks no denial. And if we are compelled to hold our noses, we may nevertheless be disposed to shed a tear. 


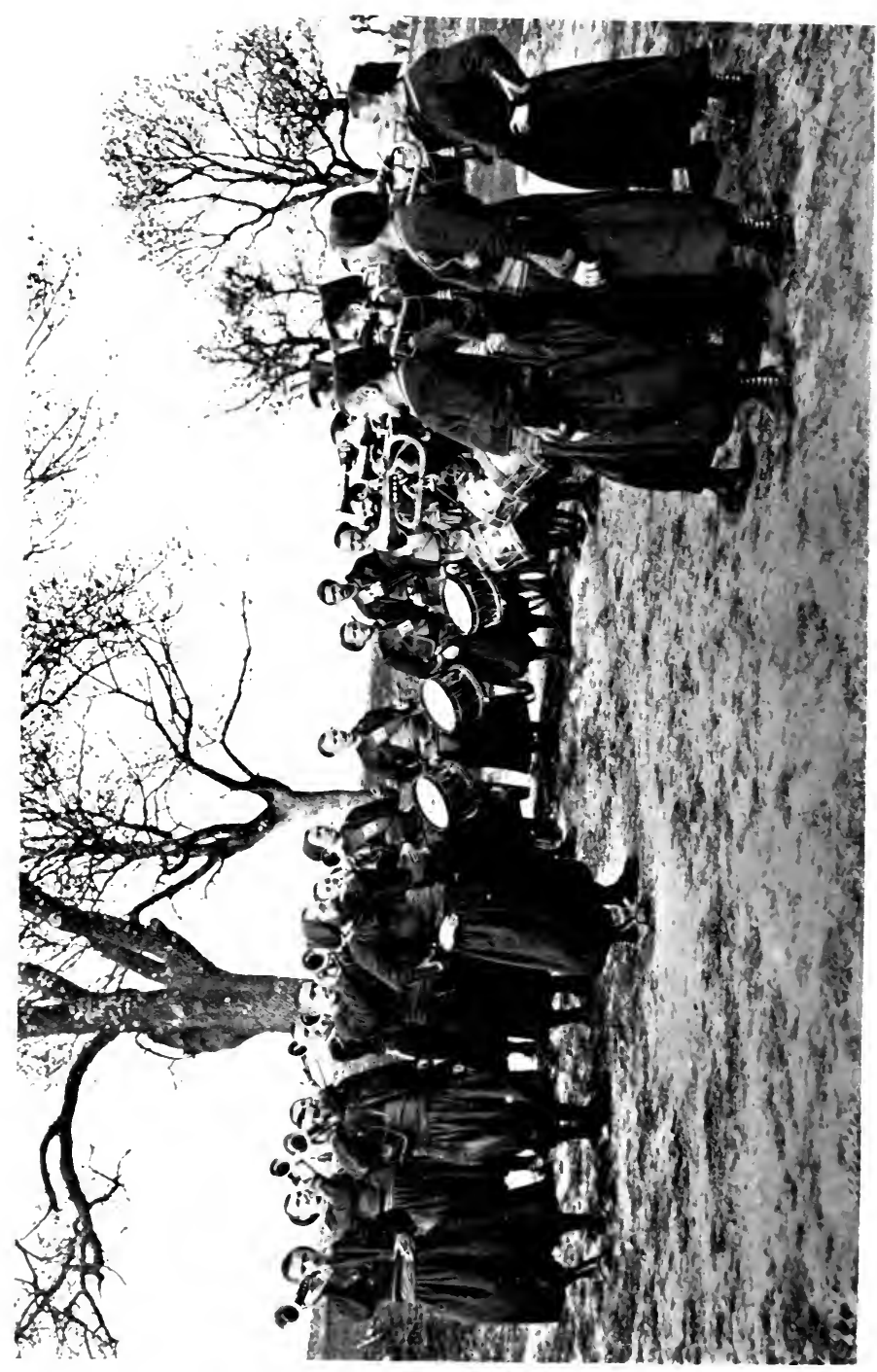




\section{The City of Precipices}

As becomes a city set on a hill, Constantine is more retentive of its ancient customs than a port like Algiers, which is subject to the levelling influences of the sea and its traffic. Here, for example, the Jewesses retain their distinctive dress. They delight in bright colours, and in heavy barbaric jewellery, such as broad bracelets and large circular earrings. They wear a peculiar head-dress, a sort of lace veil with gold or gilt ornaments, surmounted by a pointed cap. The girls affect a very diminutive form of this cap, generally of brilliant red or blue, stuck jauntily on one side of the head. They are very lovely, these Jewish girls, the finest type of their race, with noble features and clear olive complexions. In point of refinement and the carriage which marks good breeding perhaps no race touches such wide extremes as the Jewish; for some reason or other the Constantine Jews are at the top of the tree.

You may sit in a café of the Place de la Brèche and watch the endless pageant of commingled East and West. The military note is predominant; Zouaves and Spahis are everywhere. Behind a series of transport 


\section{About Algeria}

waggons of the Chasseurs d'Afrique a motorcar hoots impatiently. Next a group of little donkeys bearing loads, heads low, and ears wearily flopping. Then carts heavily laden with stone, drawn by five horses,-sometimes a grey team, sometimes a brown,-harnessed in single file, the driver walking by the penultimate horse; a group of neat French children on their way to school; an Arab lady of high degree veiled in the daintiest grey chiffon, riding on a caparisoned mule and holding a lovely child before her; an old Arab seated on a mass of saddle-bags which almost hide his donkey, waggling his feet up and down after the Arab manner, even as civilized man works a salmon-rod; and as you turn to go there comes a troop of men chanting a dull Gregorian measure, and bearing something on a stretcher covered with a green and gold flowered cloth; - an Arab on his way to his last resting-place.

Such is a fraction of the cosmopolitan and parti-coloured crowd. And as you watch you will reflect how much it owes to the fact that the natives, high and low,-you do not see much of the former,-wear a distinctive dress. 


\section{The City of Precipices}

The Arab's robe is often shabby and often unclean; but it avoids the meanness and vulgarity of European clothes. The working classes of Northern Europe have discarded their suitable dress of the past;-even the lingering smockfrock, most appropriate and dignified of coverings, has gone,- they habit themselves in the cast-off clothings of the well-to-do, or in badly-made imitations of them. The women suffer in appearance more than the men, but both combine in their personal aspect to contribute to the grim squalor and hideousness of our meaner streets.

It is said that the plateau on which Constantine stands is honeycombed with caves and subterranean passages, and that formerly it was possible to walk round the city underground. Probably these caves were excavated by the river before it had carved out its present bed at a lower level. These great natural storehouses were used in troublous times for the keeping of provisions and munitions of war; and during the French attack of 1837 many of the inhabitants took refuge in them. They are now for the most part bricked up, but a very remarkable grotto lies beneath the 


\section{About Algeria}

Hôtel de Paris, and may be visited from the hotel.

There is a museum at the Mairie. It is, as Mr. Lucas found the Soane Museum in Lincoln's Inn Fields, very difficult to get into ; and it is still more difficult to get out of, especially if you are a sympathetic listener. The good lady whose place is in the porter's lodge, and who has the key, will, when at leisure, conduct you to a long room containing the usual assortment of battered coins and broken pottery, and one gem, a bronze statuette of Victory, found beneath the Kasbeh. When you are sufficiently depressed by the antiquities, your guide has something in store for you. She will show you-you only, you are given to understand; it is an exception;- the marble staircase and the saloon in which the Mayor receives. And very fine the marble columns and marble panels are, and you will notice how here a butterfly with long tails is faithfully depicted in their rich grain, and there the head of an old Arab to the very life. And if you will have the goodness to look out of window, you will see a house on the hill opposite, and just beyond it on the other side 


\section{The City of Precipices}

is the quarry from which all these marbles come. And in all Algeria there is no such a Mairie as this. And you may be led to discuss systems of local government, and to mention that you yourself, who speak, take some small share in such matters, if only as a member of an Education Committee, or a County Council, or what-not. And you will perhaps be pained to discover that the very name of your important county town is unknown to your entertainer; a pain to be mitigated later by the reflection that the caretaker of its Town Hall is perhaps not fully informed as to Constantine. And the pièce de résistance comes last. You shall see the salon in which the Mayor conducts the marriages. And very suitable and dignified it is. Has your Mayor so fine a marrying-place? You are constrained to confess that as far as you are aware your Mayor has nothing to do with any marriages but his own. A quick look as at an impostor detected, a shrug of the shoulders, and a sigh for the barbarous condition of foreign countries, and it is over.

Constantine is a busy place. It is naturally a great corn-market. It has long been celebrated 


\section{About Algeria}

for its leather goods. In their manufacture a large number of tanners, saddlers and shoemakers are employed. Here are produced all the elaborate articles of harness affected by Arab cavaliers, often curiously wrought and of high price. And there is a considerable woollen industry. Here are woven the baiks and burnous which form part of Arab dress; and certain finer articles, called gandouras, made partly of wool and partly of silk. And the development of the minerals of the province, especially zinc, iron-ore and phosphates, is bringing activity and prosperity to Constantine.

The last conquerors have indeed set their seal upon the ancient city. They have wrought more damage to its beauty in less than a century than the Arabs in a thousand years. They have done their utmost to reduce it to the level of a common French provincial town, and they may boast such partial success as its conditions permitted. We are inured to regarding such proceedings as inevitable. We have let our own towns grow as the speculative builder willed; we have spared nothing except by accident; we should have dealt with Constantine very much as the French have, perhaps more out- 


\section{The City of Precipices}

rageously. The folly and iniquity of it all is dawning on us too late, we are beginning to see that the nineteenth century betrayed its trust ; it destroyed wantonly in time of peace what even the stress and exigencies of centuries of war had spared.

The cliffs of Constantine's great gorge still hold aloft its plateau ; if they enclose a city unworthy of their protection, such a condition is perhaps, relatively to their own permanence, merely transitory. They will doubtless see the passing of all that our banal age has set up ; it is fortunately not built for lasting. And a more enlightened race of men may yet arise to crown with the towers of a noble city the finest site in the world.

From Constantine the traveller will doubtless turn his face southwards. He will have in front of him the ruins of Roman cities on the northern slope of the Aurès mountains, for which Batna, I 22 kilometres from Constantine by road, is a convenient head-quarters; and further on, after passing through a gorge which severs the range, he will enter the true Sahara and, at II 6 kilometres from Batna, reach the oasis of Biskra, the much honoured and much 


\section{About Algeria}

sung. The railway takes during part of the journey a somewhat different course from the road, but the distance is about the same, the journey occupying seven or eight hours.

There is nothing very remarkable about the first part of the route. The country is bare and somewhat marshy. Half way to Batna both rail and road pass close to two salt lakes, which are the haunt in winter of flamingoes and wild duck. A little further on a glimpse is caught of the Medrassen, a remarkable monument recalling the "Tombeau de la Chrétienne," near Algiers. It is interesting to the archæologist, but perhaps hardly repays an ordinary traveller for the trouble of visiting it. Different opinions are held as to its purpose ; it was probably the burial-place of the $\mathrm{Nu}$ midian kings, perhaps of Massinissa, in which case its date would be about 150 B.c.

At Batna the road to Timgad and other ancient cities of the Roman frontier diverges to the eastward. Proceeding northwards we continue to ascend for a few miles, until the watershed is reached, where we enter the valley of the Oued Fedhala, the river which runs southward to Biskra and the desert. East 


\section{The City of Precipices}

of the road lies the great mass of the Aurès mountains. On their northern side they slope gradually, forming, in the manner of Algerian mountains, great plains, which again, after the lapse of many centuries, have been brought into cultivation. Their southern face rises more or less precipitously from the Sahara, and defines, as has been suggested, the limits of European colonization.

The mountain fastnesses of the Aurès, seldom penetrated by the stranger, are the home of a race, the Chawia, which possesses remarkable characteristics. In the main a branch of the aboriginal Berbers, they have been preserved by the seclusion of their mountains, like their cousins the Khabyles, from any Arab admixture. But there is little doubt that they represent also the débris of the Roman, Vandal, and Byzantine colonies driven to the hills by the Arab invasion. Even so were the last remnants of Romano-British civilization driven to the highlands of Wales and Cumberland before the Anglo-Saxon hosts. In their features, their speech and their customs, the Chawia betray their classic origin. Many travellers have dilated on the beauty of their 


\section{About Algeria}

women:- " their well-featured countenances, fair-curling locks, and wholesome ruddy looks." Their language is full of Latin words. "They observe the $25^{\text {th }}$ of December as a feast, under the name of Moolid (the birth), and keep three days' festival both at springtime and harvest. They use the solar instead of the Mohammedan lunar month, and the names of the months are the same as our own." In the peculiarities of this isolated people, for which I cannot personally vouch, we seem to see the germ of some of Mr. Rider Haggard's romances. 


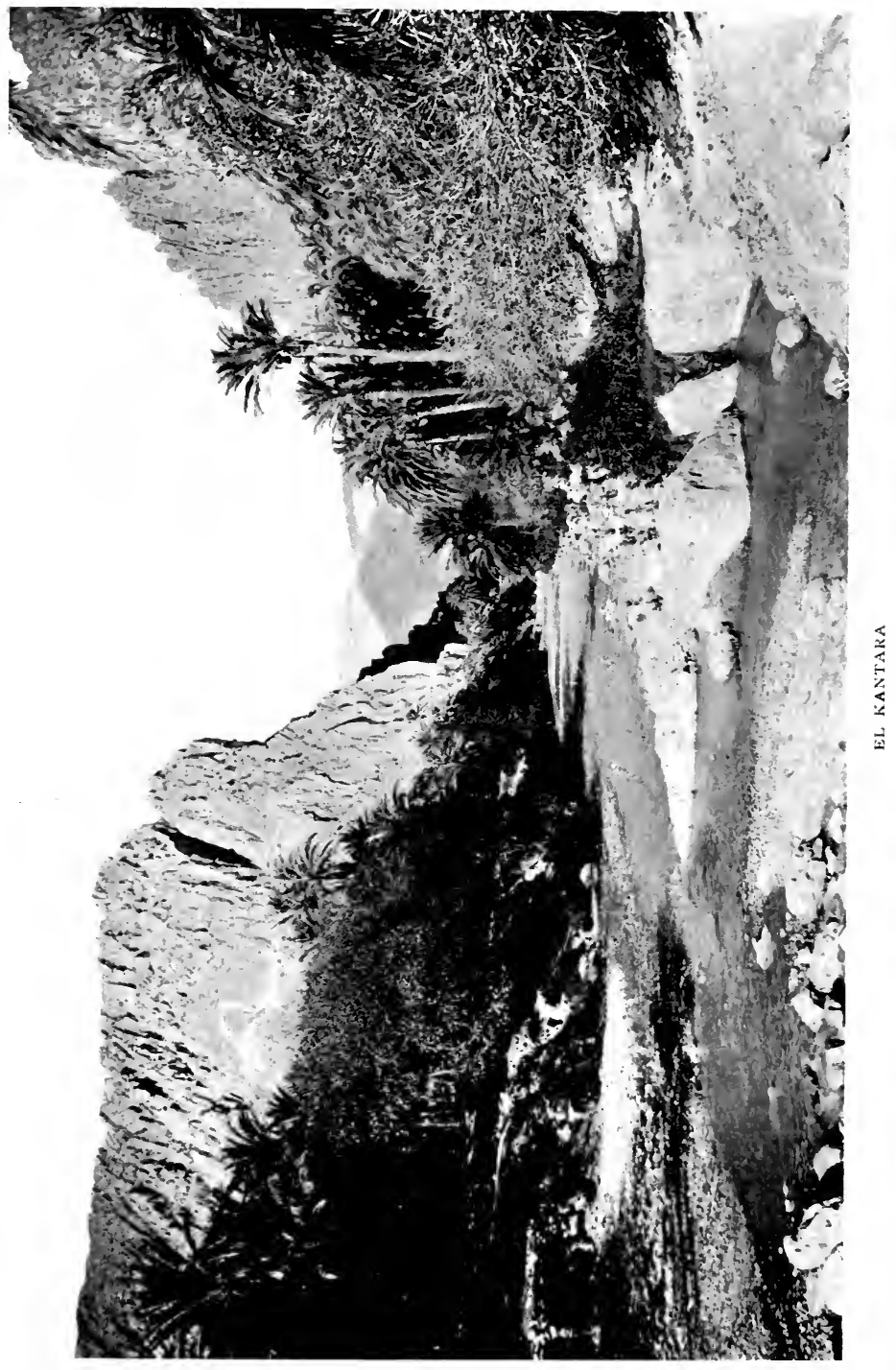




\section{VIII-THE ALLURING OASIS}

El-Kantara-The Gateway of the Desert-Biskra-Its attractions-

The dancing-girls - "Hichenstown"-A garden and a vision-

Railway extension-Conquering Mohammedans-Sidi Okba-The Arab's point of view.

"Ship me somewheres east of Suez, where the best is like the worst,

Where there aren't no Ten Commandments, an' a man can raise a thirst."

Barrack-room Ballads.

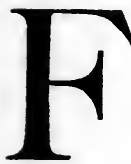

ROM the watershed to the north of

Batna the descent by road or rail is rapid to El-Kantara, where the mountain chain is riven by a deep and narrow gorge. It is called by the Arabs Foumes-Sabara, the Mouth of the Sahara. The scenery is very striking; Nature is here in a theatrical mood; the mountains are bare and rugged and of a rich yellow hue, and as one emerges from the gorge the coup d'ail is magnificent. Immediately in front is a lovely oasis, rich in palms and fruit trees, offering a delicious contrast of greenery to the rough 


\section{About Algeria}

weather-scarred rocks above. Around and below, to the southward, are the rugged foothills of the Aurès, and beyond all the great illimitable sea of sand. This is one of those rare places of the earth where nature seems to set herself of deliberate intention to produce an effect. And nothing is wanting to its success; nothing is superfluous. No one could have planned a more fitting, a more impressive, a more romantic, gateway to the desert.

We continue to descend by the river, which is soon to meet its doom in the sand, through a strange country which suggests in its apparent absence of design the effect of some vast catastrophe,- " the quarries of an enormous desolation." From the seamed and wrinkled and time-worn cliffs, with their endless repetition of narrow buttresses, stand out weird pinnacles as might the ruins of a fantastic castle, or the fangs of some huge primeval monster, "the dead bones of the eldest born of time"; while the floor of the valley is covered with curiously regular pyramidal heaps, which bear the semblance of man's fashioning. Such a landscape might serve for a poet's or painter's Inferno; such may be the scenery of the moon. 


\section{The Alluring Oasis}

Little by little we leave this nightmare of the foot-hills and emerge into the plain. We pass several little oases, and traverse sandy areas with scanty scrub. The river, or its bed, is ever with us, with here and there an oleander growing on its banks. Where water can be led away from it, a little ground is irrigated, and corn is sown. But ever'we are tending to the open desert. And at last, when we have passed completely from all contact with the hills, and know that we have attained the great Sahara, at last we come to Biskra.

It is a little difficult to analyse the charm of Biskra. The charm is great and the attraction strong. They do not lie altogether in the brilliance of its sunshine, in the shade of its palms, in the richness of its colouring, in the exuberance of its life. These things we may meet elsewhere. Biskra has other qualities; it is barbaric, African to the core, tropical in its intensity.

Biskra is barbaric. To one entering by rail or road its trim streets and squares, and housing himself in a hostelry which might be anywhere within the bounds of the civilized world, this is a hard saying. Yet he may soon perceive 


\section{About Algeria}

that its veneer is very thin and understand that it is very transitory. A hot wind from the desert in April, and it is gone, and the real Biskra will reassert itself. But even during the months of the incursion of the biverneurs, the barbaric note is never absent; to the ear that listens it is predominant; it rings more shrill by force of contrast. The troops of snarling camels, with their loads from the Great Beyond, the clash of African musicless music, the thronging crowds of jostling races in its markets, the hooded figures crouched motionless round its cafés, the bedizened native harlotry which stalks unashamed,-nay, proudly as mistress of the town,-in its streets; all are there to mark its essential savagery. A few hours ago in the upper lands behind the desert gateway we breathed the chill atmosphere of Europe; at Biskra we have passed the bounds; sun and sky and earth and man and outrageous woman combine to tell us that at last we have entered Africa.

It may be that therein lies Biskra's attraction to the jaded European. It is all a little unnatural from the European point of view. There is a sense of walking on the slopes of a 


\section{The Alluring Oasis}

volcano, or of playing with fire; and if we may believe our novelists, European nature under its influence tends to eccentric and eruptive manifestations. Yet its frequenters exhibit little outward sign of disturbance. German tourists, arrayed indeed as if about to combat a Touareg onslaught, yet read novels peacefully in the pleasant seclusion of the hotel garden; the Kodak fiend stalks his prey; the traffic in post cards goes merrily along; but we cannot escape an uneasy feeling that this nonchalance is a cloak. Perhaps the novelists have got on our nerves.

Biskra consists of a modern French town and garrison, and several more or less distinct native villages grouped together on a large oasis, a strip of cultivated ground between three or four miles in length, with an average width of half a mile. It contains an immense number of palm trees, the chief source of wealth in the great Sahara. There is abundant water from springs, and during winter from the river, which conveys the snows of Aurès to the desert, and is finally lost some miles further to the south. It has a swarming native population, of every North African race, and every 


\section{About Algeria}

hue. There is obviously a very great infusion of negro blood; no doubt because Biskra is situate on a highway of the nations, at a point where the caravan routes from the extreme south reach the mountain lands of Barbary. These natives of various races are collected in great numbers in the morning market, and throng the neighbouring cafés throughout the day, where squatting figures play interminable games of dominoes and backgammon. Conspicuous in the crowd are the dancing girls of the Ouled Nail tribe dressed in tawdry finery, hung with barbaric jewellery and masses of gold and silver coins, their hair mixed with wool and plastered with grease, their faces tattooed and darkened with $k b o l$ and benna. These women delight their patrons with their danses à ventre in the Cafés Maures at night, and later sit-waiting and watching-on little balconies in the street which is assigned to them. Many attempts have been made by French and English writers to shed a halo of romance over these unfortunate beings. The whitewashing of the harlot is a common literary pose. The story that they come to the desert towns to earn their dower and subsequently return 


\section{The Alluring Oasis}

to their own tribe and marry may have some foundation; such a procedure is not unknown in other parts of the world; but to judge from the appearance of some of them they are a long time thinking about settling down.

It may, at any rate, be said of these girls that they are not a mere " exploitation of local colour," got up for the benefit of the tourist. They are a genuine native product, flourishing no less in the oases of the Sahara seldom visited by Europeans than under the shadow of the hotels of Biskra. Their danses excite their native admirers to great enthusiasm, they often provoke furious jealousies, and are sometimes the object of extraordinary prodigality. Some of them appear to affect an air très grande dame. "Celles des Ouled-Nail qui sont de grande tente apportent dans leurs relations avec leurs visiteurs toute la générosité et la délicatesse que comporte leur origine. Il suffit d'admirer une seconde l'épais tapis qui sert de lit pour que le serviteur de la noble prostituée apporte à son amant d'une minute, dès qu'il a regagné sa demeure, l'objet qui l'avait frappé." 1

1 Guy de Maupassant, "Au Soleil." 


\section{About Algeria}

Biskra may be compared with a Nile town such as Luxor, if one can imagine Luxor without the river, without the temples, and, it must be added, without the flies. But it is a desert town, the town of an oasis, born of springs of water rising in a dry place, and it revels in the desert sun and sky. It is most pleasant when the sky is cloudless and the air still. But its beauty is greater when a moderate wind is blowing and light clouds are passing. Then are glorious deep blue shadows thrown on scarred cliffs of the tawny Aurès range. The tower of the Royal Hotel is a vantage point from which to view Biskra and its landscape. Thence you may note the extent of the oasis, the belts of palm trees in the distance which mark the existence of other oases, and miles to the south the dunes of shifting sand which to the imagination of most of us represent the real Sahara. Especially beautiful is the scene at sunset. The changing lights on the mountains, the ruddy glow all around, the peculiar quality of transparency in the sky when the sun has set, and perhaps Venus appears and hangs like a lamp between earth and heaven,only in the desert may we behold these last 


\section{The Alluring Oasis}

glories of departing day. The shady, birdhaunted garden of this hotel is a very haven of shelter when the desert wind blows strong and raises the light dust of Biskra in the street without. It is surrounded on all sides by the hotel buildings built in the spacious Oriental manner with corridors opening to the garden and pleasant balconies above.

Biskra of the tourists, urbs circumcurrentium, is in a fair way to rechristen itself Hichenstown. The novelist and his not very edifying story pervade the place; they are thrust at you everywhere with damnable iteration. And the worst of it is that however mawkish the book it has undeniable power, and if you are unfortunate enough to have read it you will be unable to avoid recognizing at every turn the scenes in which the much-longing-to-be-loved heroine and her uncouth lover played their parts. You will probably not have been in the town many hours, perhaps not many minutes, before a guide will accost you and produce with much dignity a visiting-card of $\mathrm{Mr}$. Hichens, on which something is written. If you express neither interest nor emotion he will regard you with a mixture of incredulity and pity. 


\section{About Algeria}

What are you here for but to worship at the shrine of the marabout Hichens? Hichens has made-or marred-Biskra, and Biskra is not unmindful. There is little or nothing to guide you to in Biskra, wherefore is it full of guides. They are an ever-present nuisance. The easier course is to engage one, he will at least keep off the others; if you have more grit you may set out to prove yourself unguidable; every guide's hand will be against you at first, but you will reap your reward. You will have no difficulty in hiring a guide when you really want one, and he will respect you the more. The Arab is no mean judge in such matters. The authorities have endeavoured to mitigate the nuisance by licensing certain men to act as guides; but they have not altogether suppressed the unauthorized, and the licensed merely give themselves additional airs. Silly sentimental visitors have aggravated matters, and have, moreover, turned many of the boys and girls into impudent beggars. Books have actually been written embodying the views on life and religion of these petted striplings; their remarkable inaccuracies in serious matters suggest that the youth of Biskra is not averse 


\section{The Alluring Oasis}

from " pulling the legs" of its amiable patrons. It is all rather sad. But the debasing effect of the inconsiderate tourist is not peculiar to Biskra.

The garden of Count Landon is botanically interesting, and a delightful refuge from glare and dust and importunity. It is not in the ordinary sense a garden; it is rather a great plantation or shrubbery divided by winding paths. The excessive neatness of these paths, built of hard mud and carefully sanded, rather spoils the effect of the wilderness to an English eye. There is abundance of running water, and the palm, which likes to have "its toes in the water and its head in the sun," flourishes exceedingly. With it are many bamboos, peppers, oranges, and various species of ficus, - the usual subtropical assemblage. I observe no treeferns; yet the conditions appear very suitable. It is one continuous jumble; there is no attempt at grouping, which would perhaps have produced a more noble and more natural effect. But as you come suddenly here or there to the verge of this thicket, you are startled and delighted by the contrast of mellow shade within, and the shimmering 


\section{About Algeria}

glare without; - a contrast quite after the manner of Biskra, which revels in the juxtaposition of the incongruous. Those who come to the desert in search of peace and quiet may find themselves in the plight of the guests of a Swiss innkeeper who advertised : "My hotel is recommended to those in search of solitude; thousands come here in search of solitude every summer." But in the garden of $M$. Landon you may be at rest, and dream dreams and see visions, as I did. I had been reading certain modern French writers who are concerned to prove that the inhabitants of this country, the indigenes, are not Arab at all. They don't deny the Arab conquest, but hold that the claim to have "come in with Okba" is as empty a boast as among us is the assertion, "We came over with the Conqueror." They are arguing to a case. If the native is not of Semitic origin there is hope for him. He has been more or less Christian before, so he may be Christianized again, or anti-clerical radical socialized, or whatever is necessary to make him an up-to-date Frenchman. But with all their theorizing nothing is effected. The Arab,-or Berber,-goes on in his Arabian,-or Berberic, 


\section{The Alluring Oasis}

-way, unmoved by any attraction of French politics and irreligion. How is he to be broken in ? A chance remark of an American fellowtraveller opened to me the great discovery. History supplies other instances of idle words changing its course. There is to-day a great civilizing influence at work on cosmopolitan lines such as the world has never seen before. It has already profoundly affected some of the greatest of human interests,-religion, commerce, and clothes. It will ultimately bring about the abolition of war, because no one will have time to fight. It is permeating the most unlikely quarters; if I mistake not my German neighbours this evening at dinner were continually alluding to it; and what Germany thinks to-day, Europe will think tomorrow. The Arab, or Berber, must be brought into the movement. He must play golf. My American friend informed me that golf has changed the habits of the American business man. It appears that since Columbus arrived this individual has never taken any exercise; he has sat in his office glued to his desk from dewy morn till long after sunset. All that is over, and in a moment. At 3 p.m. 


\section{About Algeria}

he now furtively affixes to his office door a notice, "Back in ten minutes," and is off to the American Sandwich. Saturday is a whole, not a half, holiday; and Sunday has become a day of especial unrest. If in the twinkling of an eye such a slave of ingrained habits may find salvation, need we despair of the poor Arab, or worry ourselves about his pedigree? To all appearance he is usually short of a job ; his posture of seemingly permanent repose is explained to me as one of waiting till his dates are ripe. Golf will alter his whole attitude of mind as of body. Local conditions are most favourable. The Sahara contains the finest sand-bunkers in the world. The creation of greens is merely a matter of sinking Artesian wells, a laudable process on which the French Government is already embarked, but with no full appreciation of its real significance. Temporary club-houses of galvanized iron would meet all requirements for the present. At once the Arab's (I must continue to call him the Arab, in spite of my French authors) distinctive dress would go. No one who has not put it on can realize in what a cuirass, in what folds, he is involved. As he is he could 


.




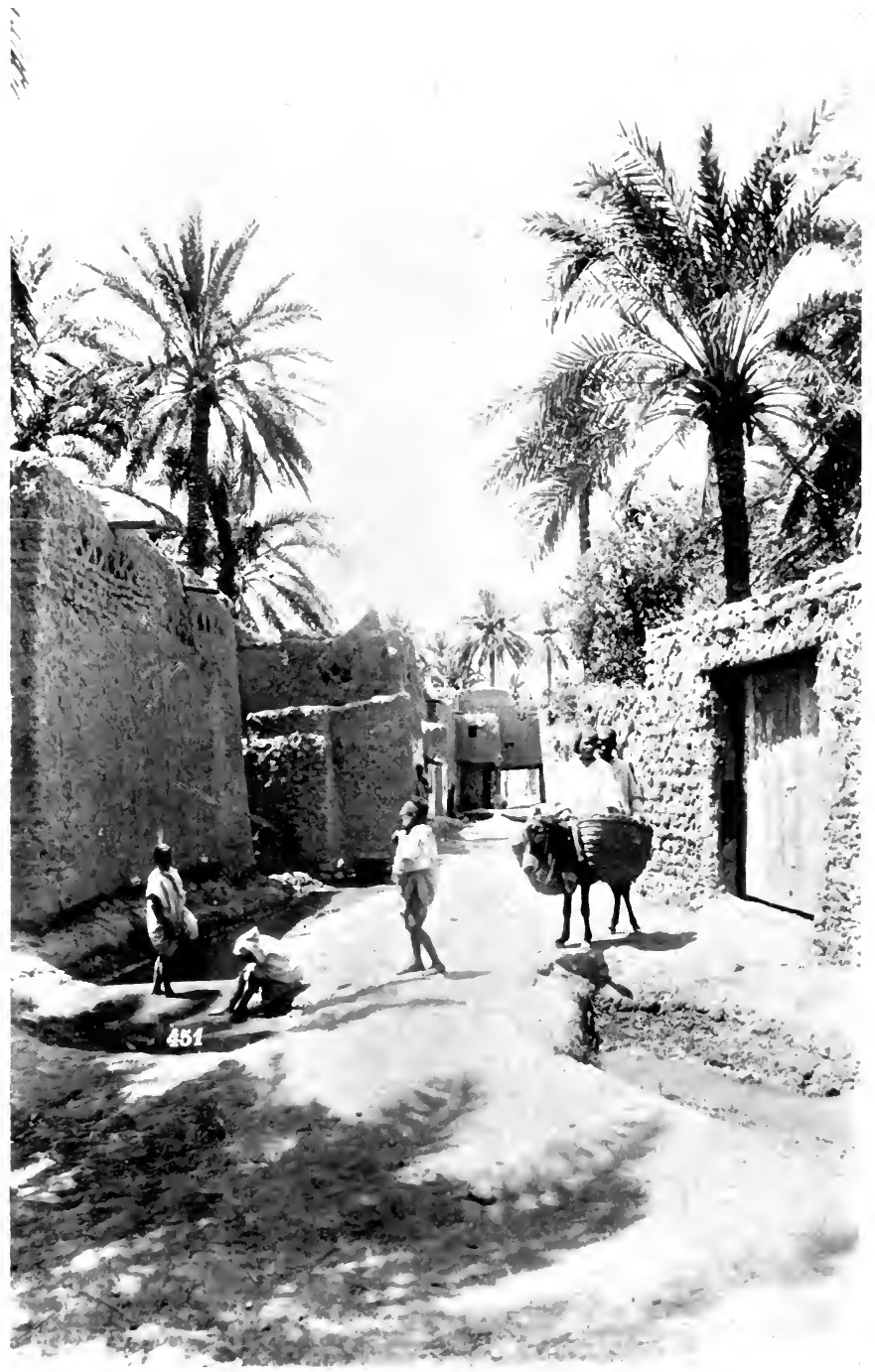

(I.1) MISKRA 


\section{The Alluring Oasis}

never hope to drive a decent ball. Array him in a Norfolk jacket and knickerbockers and putties (I observe that his French conquerors are greatly affecting putties) and his aloofness disappears. At a stroke he enters the worldmovement; Colonel Bogey will oust the Lord Okba ; and when Hadji ben Mohammed ben Yakoub comes over to represent the Biskra and North Sahara Golf Club at St. Andrews may I be there to see him win.

A little way further south than the garden of Count Landon, on the Touggourt road lie the scattered native hamlets known to the French as La Vieille Biskra, the crumbling houses of a ragged population. Here is the very ne plus ultra of Arab untidiness. But the play of sunbeams through the palm trees' grateful shade turns squalor into beauty. Arab villages are often half in ruins. Their irregular construction of blocks of dried mud gives them the aspect of the homes of animals rather than of men,- the creation perhaps of some gigantic ant. When it rains they not infrequently fall down. And the labour of rebuilding is not lightly undertaken.

Biskra is soon to lose its present distinction 


\section{About Algeria}

as the end of the railway line. The rails are being rapidly laid towards Touggourt, 212 kilometres to the south, a desert town where splendid gardens flourish beneath the shade of 200,000 palm trees. The irrepressible motor-car has already stirred its dust. The prudent Michelin guide describes the road thither as piste carrossable mais imprudente $a$ suivre par mauvais temps. You are advised to take mats to lay down in the softer places for the car to run over. But what happens in the event of a serious breakdown is not explained. When the rail is finished the enterprising tourist may pass by Biskra as a mere wayside station and continue to the end. But he may be only going farther to fare worse. It does not appear that the distant towns of the Sahara present any special points of interest beyond their existence. Yet perhaps there are some to whom the desert calls as to others the veldt. But they will stick to their camels and their mules, and merely use the railway extension as a jumping-board for further explorations.

To him who strives to peer beneath the obvious surface nothing in Biskra is more significant than the statue of Cardinal Lavi- 
$=$

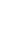
2) 


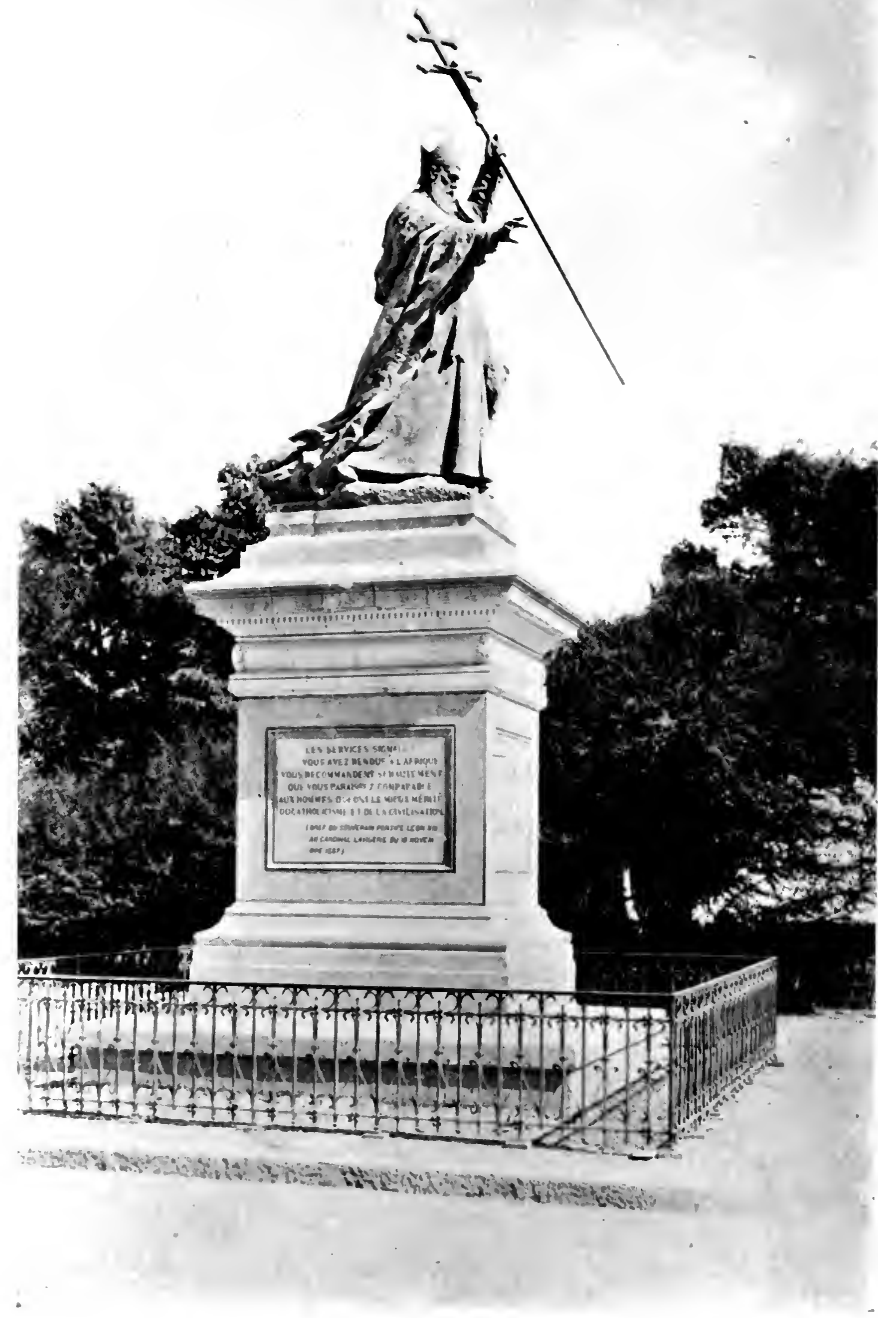

BISKRA : STATUE OF CARIINAI, IAWGIFKIE 


\section{The Alluring Oasis}

gerie. It stands in the main street close to the luxurious Royal Hotel, hard by the quarter of the Arab cafés and the street of the OuledNail dancing-girls, a symbol of the eternal amidst the evanescent, a protest for God against the Devil and the world. And it looks south. Thousands of miles away, across the vast expanse of the continent, another statue looks north. Rhodes and Lavigerie, two types of our civilization, further apart in intention and in ideals of human conduct than are their statues, look forth over Africa from their separate standpoints, the Africa for which each spent his strength. Both worked to bring to the Dark Continent the accumulated wealth of light to which Europe is heir ; they drew perhaps on different departments in the great storehouse; they directed the illumination to different points; but to evolve order from chaos, to substitute freedom for tyranny, to impose peace even, if need were, by the sword,-these were the objects which both pursued.

The neighbourhood of Biskra is rich in memories of Sidi Okba, the barber of the Prophet, and the first of the Arab conquerors. 


\section{About Algeria}

It was he who pushed westward from Kairouan through Barbary to the Atlantic, having defeated the Berbers under Koceilla and other chieftains. Arrived at the shore of the ocean he raised the standard of the Prophet crowned with the crescent, and indicating with it the course of the sun from its rising to its setting, dashed forward and breasted the waves with his horse, crying, "God of Mahomet, were I not stopped by the waves of this sea, I would go to the ends of the earth to carry the glory of thy name, to fight for thy religion and to destroy those who will not believe on thee!" On his return journey he was attacked by a force of Berbers under Koceila near Biskra and killed with three hundred of his followers. He was buried in the oasis which bears his name, and his tomb is an object of pilgrimage and veneration.

But the Berbers, if they had killed one leader, did not succeed in maintaining their independence. That they adopted the invaders' religion is not very surprising. Their previous religions seem to have sat lightly on them: idolaters, pagans, converted in numbers to Judaism, orthodox Christians, Donatists, - they 


\section{The Alluring Oasis}

had been all in turn. The dogmatic simplicity of Islam is summed up in the words, "There is noGod but God, and Mohammed is the Prophet of God." It only demands a belief in this one God and the veneration of Mahomet, last of the prophets, invested by God with the mission to bring back men to the religion of the ancient patriarchs and to the acknowledgment of the Unity of the Godhead. It is completed by belief in three revealed books, the Bible, the Gospel, and the Koran. It denies the Trinity and the divinity of Jesus Christ, who is regarded only as a prophet, but allowed to have possessed a special nature.

The simple formula of Mohammedanism was not very difficult for a man with no prejudices to accept. It meant, of course, more than appeared from its positive assertion; it was directed alike against the Trinitarianism of the Christians and the idolatry or imageworship of pre-Mohammedan Arabians. In its rejection of anthropomorphism it stands on a high intellectual plane; and it is one of the marvels of history that such an abstraction as the God of Mahomet should have been sufficient to rouse the Prophet's followers to their 


\section{About Algeria}

pitch of conquering enthusiasm. Races beaten in battle no doubt easily accepted its primary proposition. "People follow the religion of their kings," says an Arab proverb. But there was more behind. The Prophet attached to his religious doctrine a very precise ethical code, a moral system admirable on the whole in its exposition of the duties of man to man; yet in its permission of polygamy regarding women as inferior to men. And on the political side he united the functions of the priest, the judge and the king. It follows that however enlightened the main basis of Mohammedanism it is fundamentally opposed alike to Christianity and to modern theories of democratic government and the equality of the sexes. "Men are superior to women on account of the qualities with which God has gifted the one above the other," says the Koran.

After the manner of organized religions all sorts of complicated additions have been made to the originally simple rule of the Prophet, which enjoined prayer, ablutions, fasting, abstinence from wine and the flesh of the pig. These accretions are largely concerned with the veneration of saints and the exorcising of 


\section{The Alluring Oasis}

spirits. Among the former not the least is Sidi Okba, canonized rather, we may suppose, for his prowess as a conqueror and his zeal as a propagandist than for any peculiar sanctity of life.

The oasis of Sidi Okba lies about twenty-one kilometres south-east of Biskra. The road crosses a level plain, and is at present in a rather rough condition, but is being remetalled. The drive is a pleasant one, with the long line of mountains on the left fading away into a blue distance; on the right the desert with an occasional oasis marked by its group of palms. As we approach Sidi Obka the dark belt visible from Biskra takes shape. The little town lies in the midst of an immense group of date-palms, of all sizes, some of great age ; one has the honour of being described as the oldest palm in Africa. Sidi Okba has not been in any way Europeanized, it is still the unadulterated East; its houses built of mud, of one story; its streets narrow, winding and very unclean. It appears to be greatly overpopulated, and the mass of its inhabitants to be very poor. The streets are thronged with men, but scarcely a woman is to be seen. The 


\section{About Algeria}

stranger, who will do well on this occasion to bring a guide, will be quite unmolested, and to all appearance totally disregarded. A main street full of little shops, curious and interesting, leads to the market-place, which is the very climax of Arab untidiness. Sidi Okba is not a place for the squeamish.

The chief object of interest is the mosque, which is considered to be the oldest Mohammedan building in Africa. It is a square building surrounded by a portico, with a flat roof supported on twenty-six rudely carved columns. The saint's tomb is contained in a little chapel which it is unlawful for the unbeliever to enter. The mosque and its porticoes are greatly resorted to by students and pilgrims; it contains little cells in which they are lodged, and endowments have been created by pious benefactors for their support. There are many present to-day : here a single student reading laboriously a passage of the Koran written on a wooden slab; there a little group of doctors squatting in a circle apparently discussing a knotty point, but in reality only capping each other's quotations from the sacred book. In an adjoining room is the 


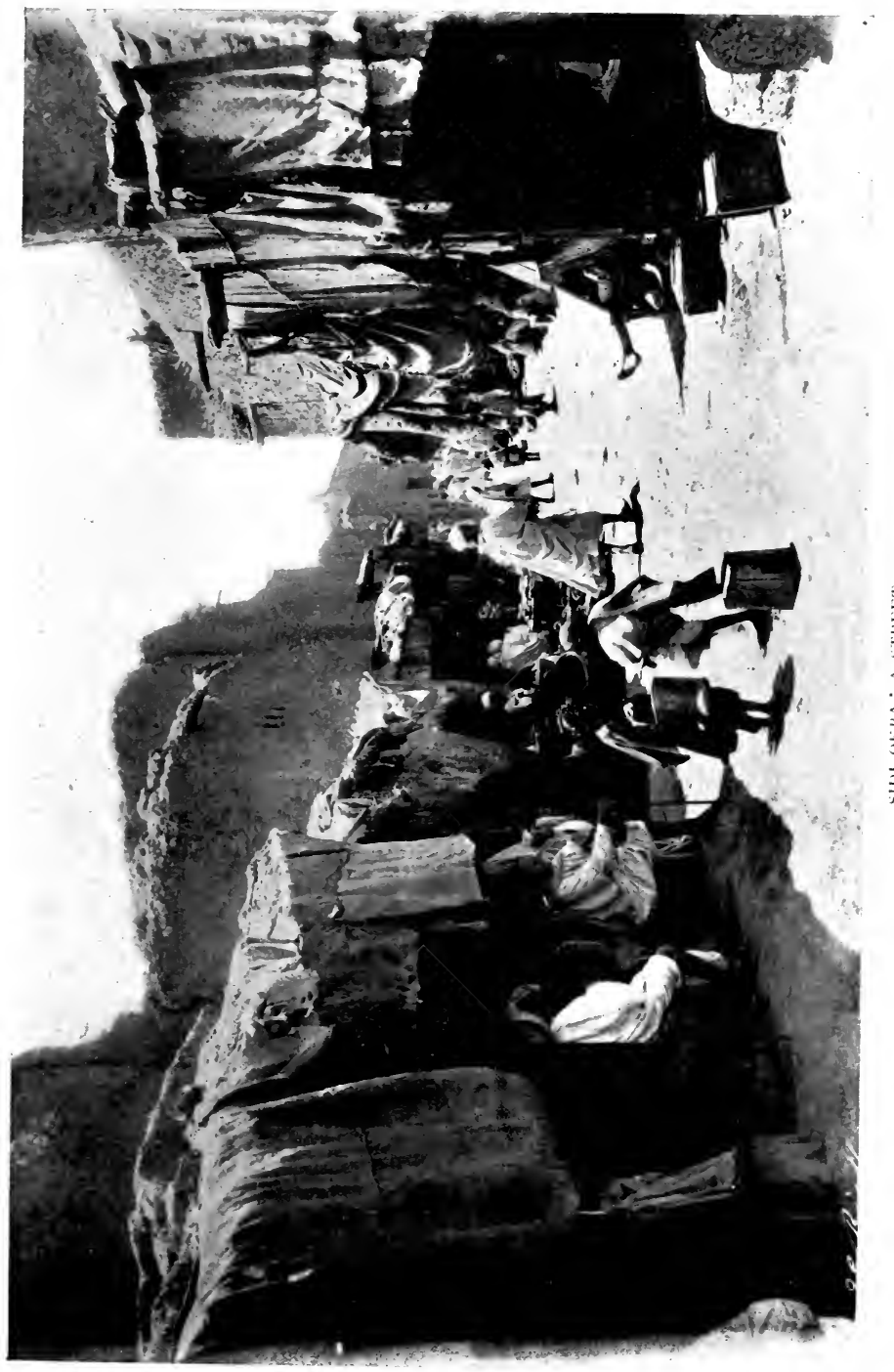




\section{The Alluring Oasis}

usual Arab school-a number of boys surrounding a seated master who is armed with a long cane, and yelling their lesson (the Koran again) with all their might. It is all very far apart from the workaday western world. Yet even into this very shrine of esoteric Islam has the West edged its way. On the walls of the mosque hang highly-coloured prints of the holy cities of Arabia, Mecca and Medina. My guide pointed them out to me as objects of interest. In the corner of the view of Medina I noticed the words, "All rights reserved. The Cairo Punch."

On one of the pillars is engraved in early Cufic characters the grandly simple inscription, "This is the tomb of Okba, son of Nafè. May God have mercy on him." The wooden door of the mosque is very finely carved in a curious design. It is said to have been brought from Tobna, in the high plateau of the Hodna, and to have been formerly covered with precious metals and jewels, which were sold for the benefit of the mosque; but this may be doubted.

To obtain a view of the township and the oasis you may ascend the minaret. Here your 


\section{About Algeria}

guide will not accompany you. Arabs object to any prying eye surveying their roofs, which are the resort of their women. They have perhaps grown accustomed to the irrepressible European, who will always go to the highest point at all hazards; he is also beneath their contempt, and in any case will depart and be no more seen. With one of their own countrymen it is different ; he may be the European's servant, but he is a fellow-religionist and not a mere animal like his employer. So the European is tolerated with a shrug. For the office of muezzin, the custodian of the mosque, whose business it is to ascend the minaret and call the faithful to prayer, a blind man with a brazen voice is in much request. If not actually, the muezzin is conventionally blind. So he will light a candle to guide you up the dark staircase, and accompany you to the top. The town lies below you and all around,-a curious collection of square mud boxes. On many of the roofs are basket-work erections, which are explained to you as the framework of tents, in which the inhabitants sleep during the great summer heats. Over the heads of countless palm trees your eye ranges to the desert, 


\section{The Alluring Oasis}

bounded on the north by the cliffs of Barbary, limitless to the south. And southwards you will gaze till you grow weary of immensity.

Perhaps nowhere more than at Sidi Okba, under the shadow of the great conqueror's tomb, may you feel the haughty disdain of the Arab. He stalks past you apparently in utter unconsciousness of your presence. You belong to a civilization which for the moment has conquered his in war. Allah has willed it. But you represent with your anthropomorphic religion, your abominable demeanour and social arrangements, especially your own lack of dignity and the licence you allow to your women, all that he holds most accursed. You attach undue importance to human life in this world; and this leads you into a ridiculous state of worry about trumpery matters of sanitation and so forth, which are quite beneath the notice of a man concerned with the higher mysteries of the universe and considerations of eternity. Your grovelling disregard of the really great things gives you leisure to devote yourself to such trifles as trade and transport, and so you grow rich, which is rather to your discredit than the reverse. 


\section{About Algeria}

Wherefore the Arab expresses his contempt for you by the supremest indifference, striving only to preserve the hem of his robe from contact with the unclean.

The ordinary traveller will perhaps leave Biskra with no great regret, however much he may have found of interest in his visit. But to those rare spirits among us who endeavour to repair the mischief caused by our first parents, Biskra presents very special opportunities. There is very little to see, and nothing whatever to do ; it is a capital place for sitting in the shade with a brilliant sky above. The Garden of Eden is an Oriental ideal; these Arabs who exist in contemplation of their palm trees are striving to live up to it. It is not at all an English ideal. The primeval curse lies heavy on the Englishman; he has made the best of it and has come to regard work as a virtue. Not only by the sweat of his brow must he earn his living; by the sweat of his brow must he achieve his pleasure. A paradise in which he could not knock a ball about or kill the other animals were no paradise to him. Yet even among our strenuous people there are emancipated individuals, to whose simple 


\section{The Alluring Oasis}

needs a sunny climate and regular meals at a comfortable hotel suffice :-

"Here with a Loaf of Bread beneath the Bough, A flask of Wine, a Book of Verse,"

such will find a congenial resting-place. 


\section{IX-THE SAHARA}

The desert in imagination and reality-Underground water-Artesian wells-Mozabites-Touaregs-The camel-Recent developmentsRailway projects-The Army of Africa.

"I've in the desert with these eyes beheld The hurrying pilgrim to the slow-stepped yield;

The rapid courser in the rear remains, While the slow camel still its step maintains."

The Gulistan.

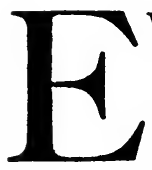

VERYONE, it has been said, has his own Sahara. For many of us perhaps the geography lessons of childhood left an impression of an ocean of shifting sand, sometimes separated from the sea by a narrow strip of cultivated land, sometimes extending to the very shore, from which majestic lions, appropriate lords of the inhospitable desert, gaze pensively at the setting sun. If we had the misfortune to be born half a century or more ago, the maps of Africa of the period, with their vast interior emptiness, suggested to our youthful imagination that 


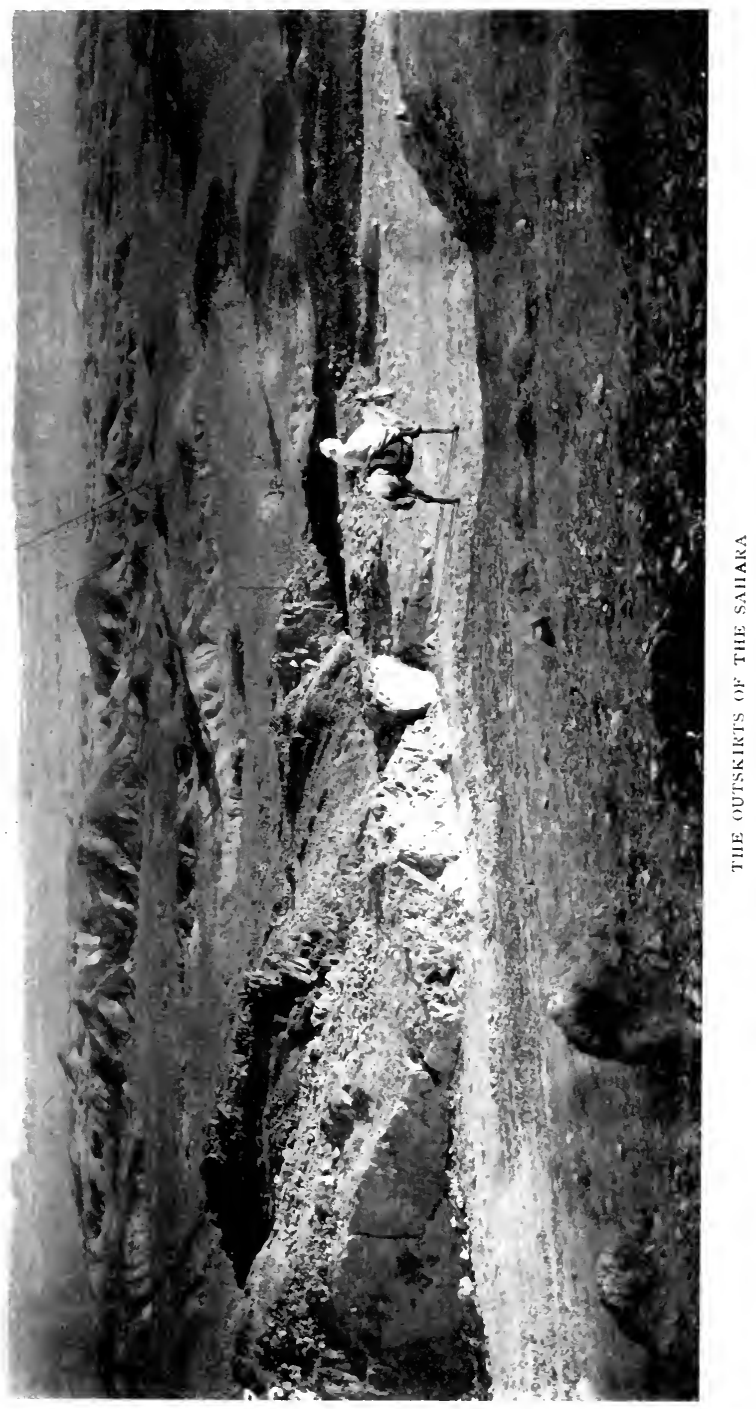




\section{The Sahara}

this unpleasant region extended over the greater part of the continent, the elephant taking the place of the lion in the more southern portions.

"So geographers, in Afric maps,

With savage pictures fill their gaps,

And o'er unhabitable downs

Place elephants for want of towns."

The last generation has seen these mediæval ideas considerably modified. Travel and war have been the means of filling much of the blank space; the arts of peace have followed in their wake; African railways would occupy quite a respectable page in a world-wide Bradshaw; and the Stock Exchange in a searching for economy of syllables has irreverently shortened the poetical Tanganyika to the practical Tank. The great flat plain is last to go; - the millions of acres of rather light soil which the French have been so unaccountably anxious to daub with their colour on the map. We have given up the lions; we know that such carnivorous beasts can only live in a fairly fertile country which supplies sufficient food to their prey. But we have clung to the plain and the sand. Never- 


\section{About Algeria}

theless it seems that they must go too. We read that you may travel for days in the Sahara on rocky hills and not find enough sand to dry your signature. So perish the beliefs of youth.

Yet to any picture of Algeria the Sahara supplies a romantic background. The sight of a caravan arriving from some distant oasis still has power to stir the imagination. Even in face of our information as to the Sahara's only partial sterility, we cherish some shreds of wonder at the men who can wring a livelihood and find the means of travel under such inhospitable conditions.

The Sahara has been defined as the region which receives only as an exception any rainfall, whether of Mediterranean origin, or from the tropical regions of West Africa. It is only relatively a desert in the strict sense of the word ; no part of it is absolutely without rain, and even in the districts which are reputed the most dry the traveller may meet with violent storms. The generally arid nature of the soil is due to the fact that water circulates not on the surface, but underground. Where it comes to light either by natural or artificial 


\section{The Sahara}

means, a focus of intense cultivation, an oasis, is produced.

The Algerian Sahara is only a portion of the great desert of Northern Africa. Yet it is ten times the size of Algeria itself. It consists roughly of two great depressions separated by an isthmus of calcareous hills. Each of these basins contains a great expanse of dunes, and the two chief groups of oases occur in their lower levels. A generation ago it was commonly believed that the Sahara was the bed of a sea which had disappeared at no very distant date; and projects were formed of admitting the Mediterranean by means of a canal. But more precise knowledge has shown that its sterility is due to other causes; that like the rest of the continent it has its ancient conformation of mountain and plain; that it has distinctive flora and fauna long established; and that the portion which lies below the level of the Mediterranean is of very small extent.

Between eighty and ninety per cent of the surface is of rock, slightly undulating and broken occasionally by perpendicular ravines and large crevasses. Here, as a rule, no water can be found, and the only vegetation is an 


\section{About Algeria}

occasional thorny shrub. With the regions of the sand dunes it is different. Their sterility is by no means absolute. They have a vigorous vegetation of their own, which will support camels, and even sheep at a favourable season. They absorb eagerly the rainfall which runs off the rocky plateaux, and acting as a sponge retain it for a long period. Their comparative barrenness is due only to the dryness of the climate; wherever they can be irrigated they become fertile.

Of the underground rivers the best known is the Oued Rir, which is met with about fifty miles to the south of Biskra, and extends as far as Temacin, fourteen miles south-west of Touggourt. Its course is marked by a number of oases, some of which have been created, and others much improved by the Artesian wells of the French engineers. The first experiment of this sort was tried as early as 1856 at the oasis of Tamerna. After twenty-two days of work, in the presence of a crowd of incredulous and scarcely friendly natives the bore produced a veritable river of a thousand gallons a minute.

"In the desert a fountain is springing." 


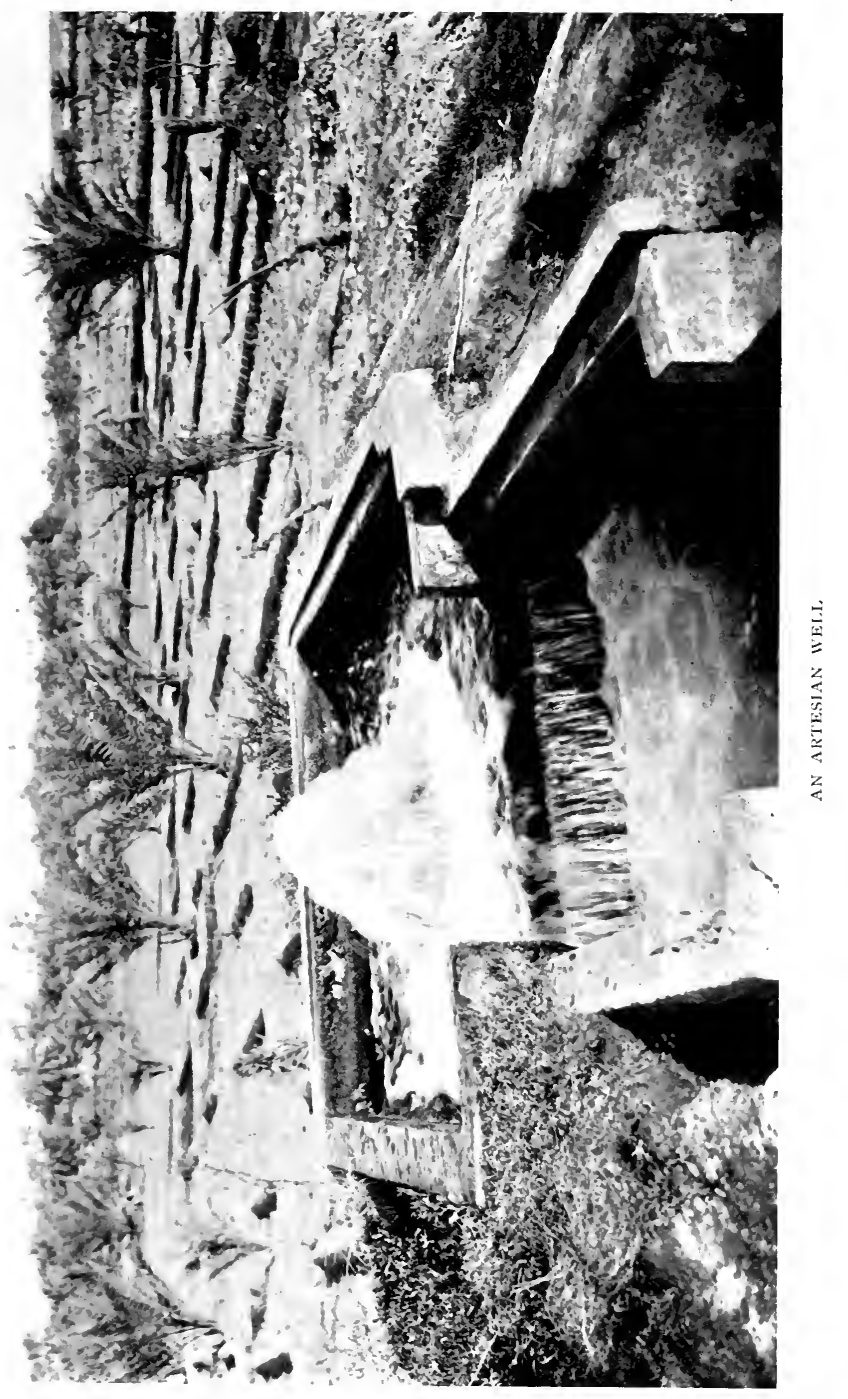




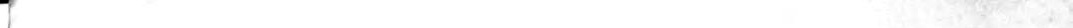




\section{The Sahara}

At this welcome spectacle, the ingrained distrust of and smothered hostility towards the stranger and his methods vanished; all gave way to a transport of joy and enthusiasm. The work thus begun has been continued with great success, chiefly by French companies; new wells have been sunk and old wells repaired; and it is estimated that the value of the oases of the Rir has increased fivefold, and their population more than doubled.

Similar results have been attained elsewhere. But while they increase the productiveness of the oases, and at the same time improve the routes and the condition of the nomads, they do not warrant any hopes of extensive cultivation in the Sahara. The conditions of life continue difficult. The oases are very unhealthy; their sedentary inhabitants are the prey of malignant fevers and chronic diseases. The summer climate is appalling; a variation between freezing-point and $120^{\circ}$ Fahrenheit in the twenty-four hours is not unknown. Those of the inhabitants, Arabs or Berbers, who have an admixture of the blood of the Soudanese negroes, are best fitted to support such trying conditions. As a place of residence 


\section{About Algeria}

for Europeans the Sahara cannot be recommended with any confidence.

Of the sedentary peoples of the Sahara the most interesting are the Mozabites; of the nomads the Touaregs, who range over the vast region to the extreme south. Both are considered to be of Berber origin. The Mozabites have already been mentioned as traders in Algiers. Their country, the Mzab, is situate in one of the most sterile parts of the Sahara, on the rocky promontory which separates the eastern and western depressions. It lies about 400 miles due south of Algiers. Here with amazing toil they have created a fertile region. They have dug wells and found water, and have built dams to intercept and retain the occasional rainfall. The contrast of their fertile gardens with the bare and fantastic rocks which surround them, a land of exaggerated sterility where Nature herself seems dead, is described by travellers as very striking. The industry and commercial aptitude of the Mozabites is very remarkable. They excel as money-lenders and in small banking business. It is said that among them a Jew must work with his hands. 


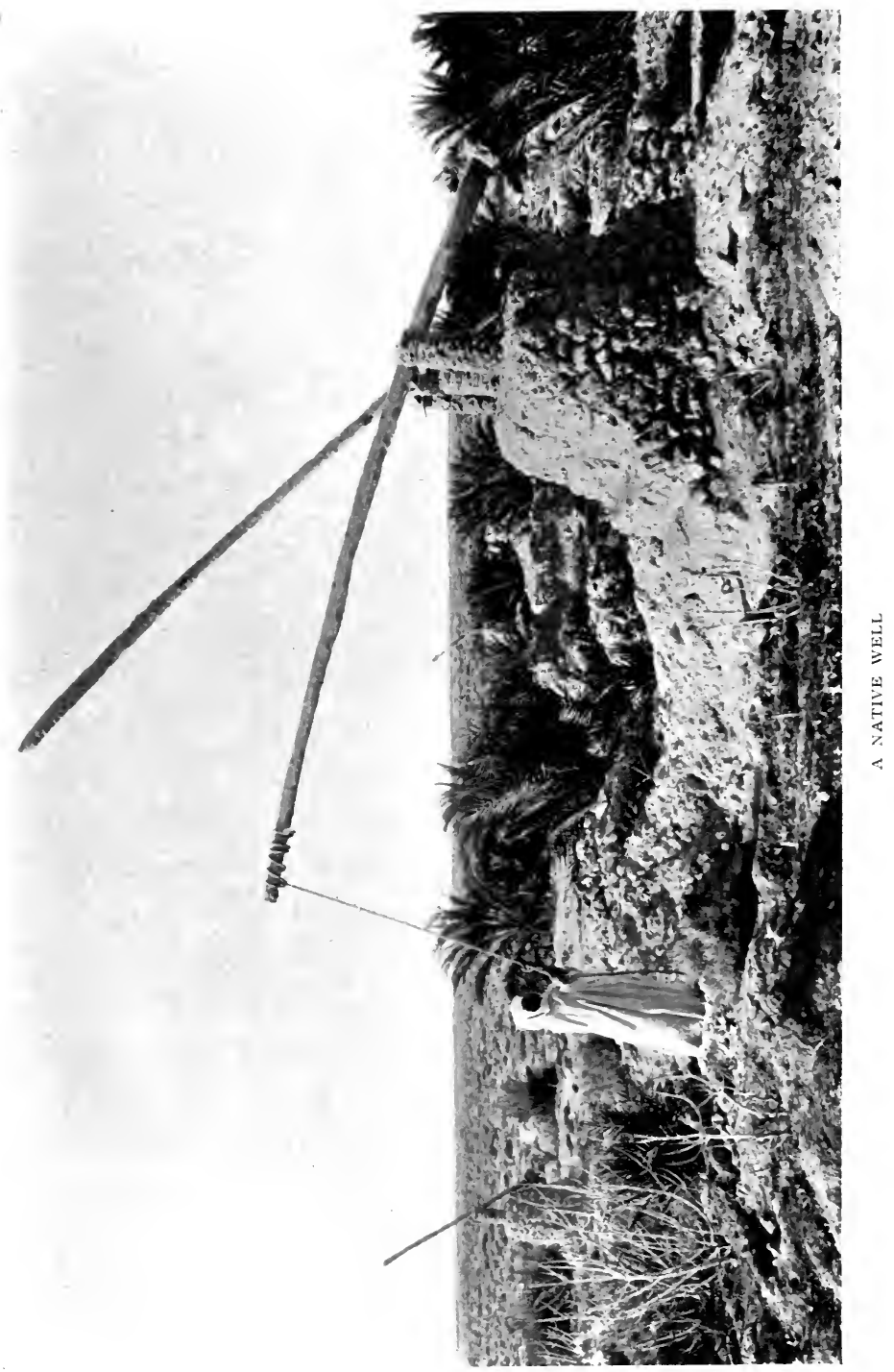




\section{The Sahara}

During the last few years, without attracting much attention from the outer world, France has quietly conquered the Sahara, or at all events brought its nomad tribes under effective control. The Touaregs, neither very numerous nor very well armed, have succumbed to persistent pressure and a few trifling defeats. Some are settling on the fringe of the oases; others drifting into the service of the State. The systematic brigands of centuries will pass, it has been said, in a few years from the Stone Age to the age of aviation. They recognize, not without humour, that their rôle of levying contributions has fallen into other hands. A captain of spahis in garrison at Timbuctoo, was ordered to pursue a caravan which had made off in the night without paying the market dues. "We also," said the Touaregs, "when we stop a caravan, do so to collect le droit de passage."

The conquest of the desert, long delayed, has only been achieved by the regular employment of the camel. For nearly a century, since Napoleon's expedition to Egypt, the French had made spasmodic efforts to utilize this animal, but with little success. The 


\section{About Algeria}

camel corps were regarded with ridicule and contempt, and the peculiarities of the beast were little understood. A common belief in fabulous stories of its powers of speed and endurance, its capacity for doing without food and water, occasioned much suffering and immense loss. In fact it requires, year in year out, as much sustenance as other herbivorous beasts of its bulk; where it differs from others is in its power to support extreme irregularity in its meals. This quality, and especially its ability to take in at one drink enough water for several days, render it of unequalled value for desert journeyings. The camel can work for six months in the year on the meagre diet which the sparse vegetation of the Sahara affords; it is necessary for his existence that he should spend the remaining six in complete rest at pasture, where he feeds voraciously from morning to night without losing a minute. "But it must not be believed," says M. Gautier, " that the camel on active service does not eat; he feeds when he has the opportunity, and the opportunities must not be rare. For a caravan of camels traversing the desert, the stomach of the beasts is the sovereign lord of marches and 


\section{The Sahara}

halts, the director of the daily programme; day and night, the fatigue and hunger and sleep of the men do not enter into the account; everything is subordinated to the single necessity of nourishment for the herd. Whenever a little edible vegetation is met with, at whatever point of the itinerary, a halt is made for several hours or several days; in the intervals, even as happens sometimes, of two or three hundred kilometres or of five or six days, progress, slow and regular, is made without truce, almost without sleep, beneath sun and stars alike. One can only stop at a pasturage; a voyage in the Sahara is a hunt for a blade of grass."

God, says the proverb, having made the desert, repaired the mischief by creating the camel. Considered absolutely it is an inferior beast of burden to the horse and mule, considered relatively to the conditions of the Sahara it is invaluable. But it must be treated according to its necessities. In the mines of Algeria, for props in the galleries, pine is preferred to oak; oak breaks suddenly when the limit of its strength is reached, pine on the contrary cracks and creaks,-it gives warning. 


\section{About Algeria}

The camel is as the oak, he gives no warning. Exhausted, he stops abruptly like a motor-car which has run short of petrol; he crouches and dies, with plenty of dignity and with an air of thinking of something else. So have ended countless camels in the service of France. But since I902 camel corps have been raised on a scientific basis; the animal used being almost invariably the mébari, a species of dromedary. A body of natives of the tribe of the Chaamba has been organized, each of whom in return for a definite sum of money supplies two or three camels, which are his own property, to exchange, to sell, to traffic with as he pleases. $\mathrm{He}$ is, in fact, a contractor. For a further sum he provides his own food, clothing and equipment. This system seems to be a reversion to an ancient custom, which the very word "soldier" recalls.

The effect has been magical. Almost without a blow the Touareg has recognized his master. The Chaamba patrol the desert and enforce French conceptions of law and order. Communications have been opened in all directions ; the tremendous journey between Algeria and the West African possessions of France is now 


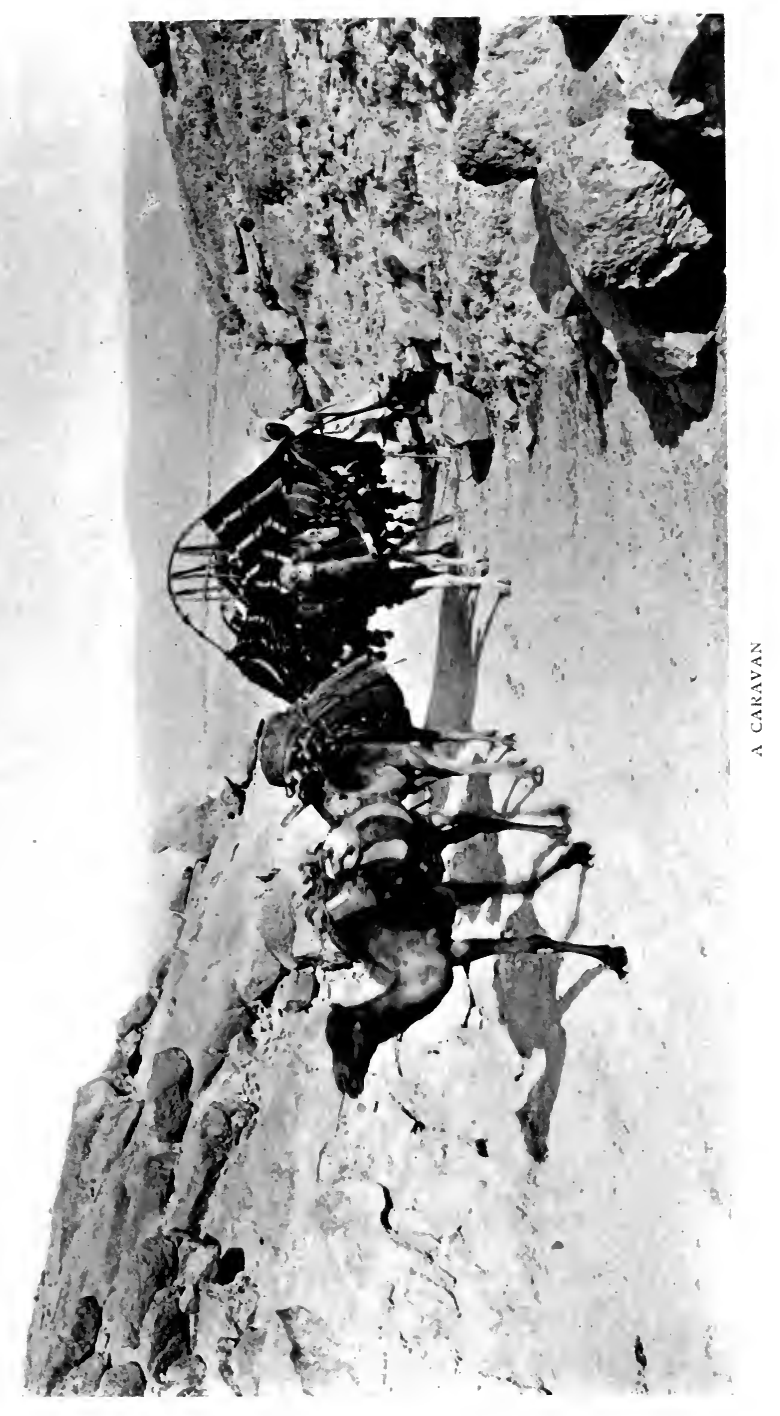


$\bullet$ 


\section{The Sahara}

frequently made without danger and without exciting remark. The mébaristes have solved the problem so long insoluble.

But a greater project is agitating the minds of the forward Colonial party, the linking of the French possessions by a Trans-Saharian railway. The scheme is not a new one. It was much discussed thirty years ago. The French Government appointed a scientific commission to study the matter, and the French public, ever ready to support a vast engineering scheme, was eager to subscribe the necessary capital. The murder by Touaregs of the Flatters mission administered a cold douche, and for the time being the subject dropped. It has been revived of late by M. Leroy Beaulieu and other writers. Two lines are projected, one to Lake Tchad; the other to Timbuctoo. The distance to be covered is enormous, in each case about 2700 miles, of which 2000 is desert. The engineering difficulties are not great, but the commercial prospects of such a line seem very poor. A train or two a year would deal with all the existing traffic, and there appears little scope for development. It is suggested that the 


\section{About Algeria}

Upper Niger may become another Nile, but even then its trade would seek an outlet rather to the Atlantic than to the Mediterranean and across the Great Sahara. The post route to South America might be shortened a little, but at what cost and inconvenience! The best hope for the would-be railway builders lies in the discovery of minerals. A mining industry would develop the Sahara as it has developed the bare uplands of the Transvaal and the icy wastes of Klondyke. But of this there is no present indication.

Meantime, in the extreme west, on the borders of Morocco, the railway has been extended as far as Colomb-Béchar, a distance of 728 kilometres to the south-west of Oran. This is a strategic line. It is in the direction of Morocco that the eyes of the army of Africa are now turned. French writers are never tired of repeating that Barbary is one, and should be undivided, that the masters of Tunis and Algeria must be lords of Morocco too. The safety of Algeria itself is said to depend on the French control of Morocco. Such is ever the language of him who would go forward. We have said it ourselves often 


\section{The Sahara}

enough, and to fix the limits of empire is sometimes more difficult than to advance them.

It may be worth while to note what is the present military force of France in North Africa. According to the project for the Budget of I9I I, the force in Algeria consists of 21 34 officers and 52,927 men; in Tunisia of 698 officers and 17,007 men. The cavalry numbers in all 440 officers and 9074 men. The number of native troops is singularly small, about 15,000 infantry and 1800 spahis. Judging by our experience in India it would be possible to make a far larger use of native military talent, to the great advantage of the population, and to the consolidation of the French hold on the country. The native troops employed in the late Morocco campaign, especially the Tunisians, bore themselves with the greatest credit.

In the Sahara special companies have been recently raised. They contain a certain admixture of French troops:-24 officers and I 23 men to 817 men. It would seem a special field for the raising of a force of natural cavalry and camel-men. 


\section{$X-\mathcal{T} I M G A D$}

The Roman frontier-Lambessa-The Empire ruined by bad financeAfrican Emperors-The plan of Timgad-Buildings, inscriptions, and mosaics-Prosperity of Roman Africa-Local patriotism-The Roman tradition.

"As in those realms where Cæsars once bore sway,

Defaced by time and tottering to decay,

There in the ruin heedless of the dead,

The shelter-seeking peasant builds his shed."

Goldsmith.

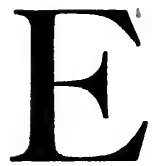

AST and west of Batna lay the Roman frontier line during the first two centuries of the Empire. It was marked by a series of cities, partly military, partly commercial; extensive ruins bespeak their ancient importance. As elsewhere in Europe and North Africa the fall of the Empire seldom meant the abandonment of the city sites; they continued to be occupied by successive generations of men, even though, like Rome herself, for a period they sank to insignificance. And their ruined buildings, public and 


\section{Timgad}

private, offered a convenient quarry to the builders of subsequent ages. It results that we are scarcely able to find an ancient city in which the original plan of house and street has not been seriously interfered with. While, as in many English towns, the main lines of the streets often follow the Roman thoroughfares, we have seldom the opportunity of studying the scheme as a whole, although all through Southern and Western Europe innumerable individual features exist more or less well preserved.

We owe the existence of Pompeii and Herculaneum to the accident of their overwhelming by ashes and lava from Vesuvius. The former has been laid bare; the excavation of the latter, a much more serious matter, awaits the day when the disposers of wealth, public or private, shall see fit to undertake a work which promises the greatest results. It happens by a piece of exceptional good fortune that here, on the southern edge of Barbary, Pompeii has a serious rival. The Roman city of Thamagudi, now called Timgad, has since its destruction at the time of the Arab invasion of A.D. 692 never been the habitation of man. To this cause 


\section{About Algeria}

alone may its present condition be attributed. It has passed twelve centuries in a great silence. Its ruined temples and baths have been the haunt of the panther and the jackal. No neighbouring town despoiled its stones, or ground its marbles to make mortar. Its columns lay prone, its temples and houses were for the most part levelled with the ground; yet a massive arch or two told through the centuries to the watcher from afar that here once stood a Roman city.

The night of centuries is past; the long silence is broken; the jackals have fled to their mountains; and a Latin race is tenderly safeguarding its heritage. Once again a road leads to the portals of the ancient city, and with infinite skill and care the debris has been cleared away. Columns have been re-erected, masonry replaced in its original position and fragments of inscriptions pieced together; a very triumph of that vast capacity for taking pains which is such an important element of French genius. One charm of the place to the visitor is that it is not exploited as a tourist resort. A little museum has been set up to hold the treasures found among the ruins, a modest hotel has been 


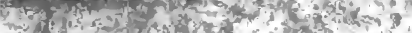

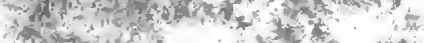

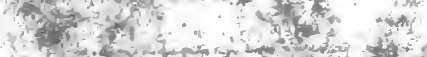

* 50 on 1. , 1 ,

a $32=0$ ?

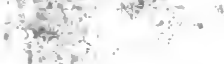

is

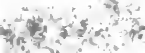

भक

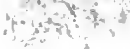

( 


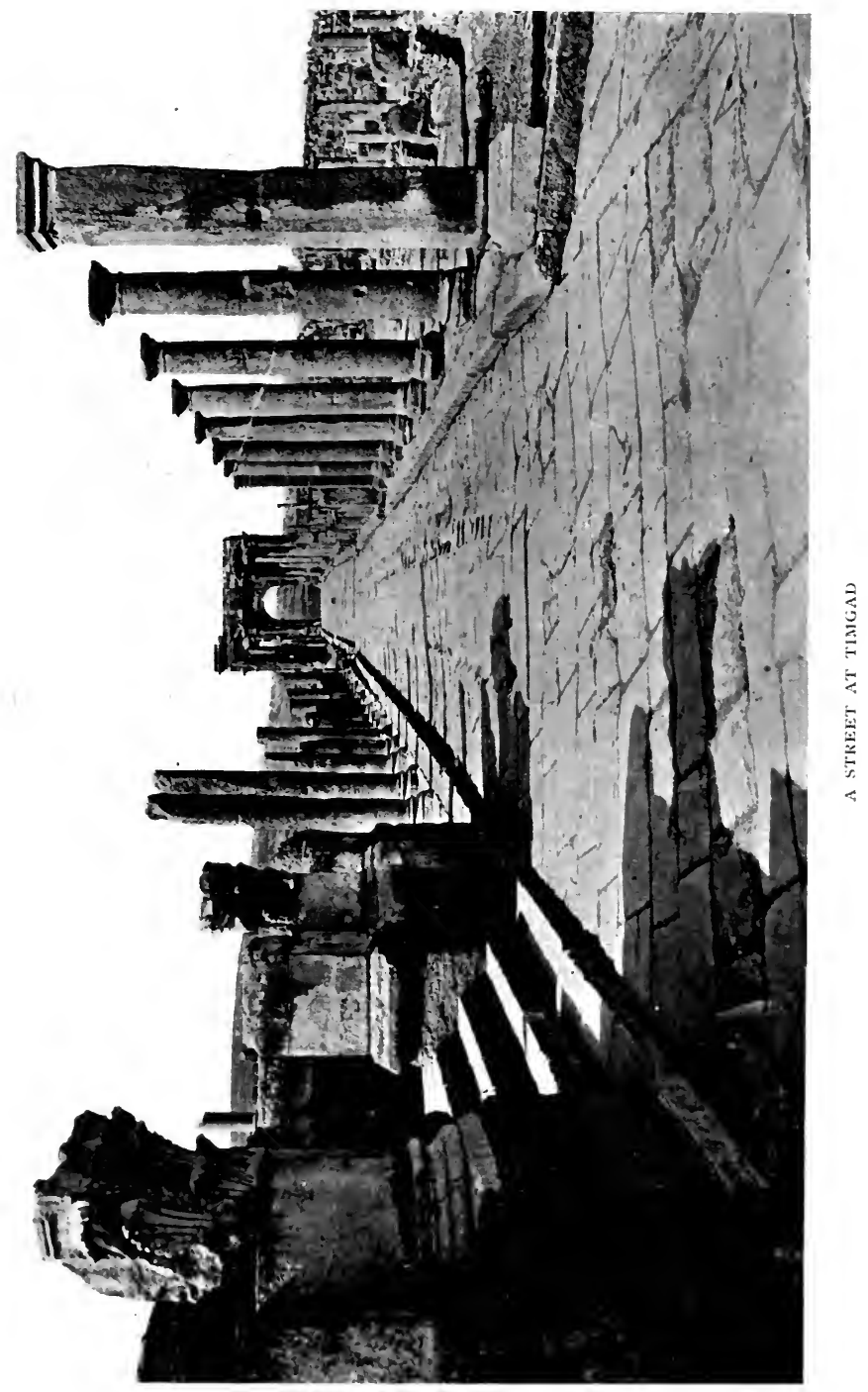




\section{Timgad}

built, and the neighbouring Arabs have been encouraged to hold a weekly market outside the walls; but there is no turnstile to be passed, you are not delivered over to a guide, no tout is permitted to worry you, and you are free to pass to and fro, to go in and out as you list as long as you don't steal or deface anything. So for a contemplative mind every possible attraction is conserved.

The Roman conquest and civilization-or rather assimilation-of North Africa were slow, tentative and reluctant. Scipio Æemilianus burnt Carthage in 146 в.c. ; it was more than a hundred years later that Julius Cæsar handed over Cirta to the soldiers of Sittius. Under Augustus a camp was established at Theveste (Tebessa), and the Third Legion, Augusta, was stationed there with the object of protecting the territory of Cirta, and the proconsular province which is now Tunisia. Under the shelter of this post, during the first century of our era, the great corn lands enclosed by the Aurès mountains were gradually brought under Roman control. The building of Thamagudi in the reign of Trajan, in the year A.D. IOO, is evidence of the importance to 


\section{About Algeria}

which this region had by that time risen. This process continued during the next two centuries. No doubt as the population of Italy declined, and her fertility decreased, Rome came to rely more and more on the corn of Africa, and more land was continually brought under cultivation. This is the significance of such a city as Timgad, lying over 3000 feet above the sea on a slope of the Aurès mountains.

Our ideas of the Roman Empire are perhaps coloured by the title of Gibbon's great work. We are disposed to think that its decline began with its establishment. Gibbon had always at the back of his mind the belief that Christianity was the cause of its ultimate ruin, and that the Empire began to totter on the day when the first Roman citizen was baptised a Christian. But for two or three hundred years, though the Empire was frequently torn by political dissensions, its material prosperity was very great. We know now that it was ruined in the end by its financial errors, its unwise and unjust system of land taxation, the grasping greed of Treasury officials and the anxiety of upstart Emperors to gratify their 246 


\section{Timgad}

supporters in the army and the Roman mob at anybody's cost.

It is a vice of civilizations to believe themselves invulnerable. As late as the fifth century it was inconceivable to a Roman gentleman that the mighty structure could be swept away; and it is perhaps true that even then it might have been saved by a return to sounder systems of finance. Even so to-day the European nations are arming to the teeth against each other, instead of husbanding their resources and concerting measures of defence against races more numerous and more prolific. The uprising of the Asiatic peoples is a fact to which we cannot be other than wilfully blind. A beginning of the trouble may be upon us at any minute.

Timgad was built by the soldiers of the Third Legion, then stationed at Tebessa. Its head-quarters were shortly afterwards moved to Lambessa, and during the second and third centuries the frontier outposts were gradually pushed forward. They occupied a line on the south side of the Aurès range, extending to the south and south-east of Biskra and then branching north-west to Bou-Saida. At least 


\section{About Algeria}

in some districts a ditch and rampart marked the limits of the Empire.

Lambessa grew into a large city said to have contained 60,000 inhabitants. Its considerable ruins, of which the most important are the Prætorium and certain arches, are visible to-day. The importance of the position is realized by the French, who have large barracks and a force of 4000 men at Batna, only a few miles off. Striking evidence of the success of Rome's treatment of subject races is to be found in the fact that with all the wealth of numerous great cities to protect, her military force in North Africa consisted only of one legion of 5500 men and auxiliary forces of infantry and cavalry, making a total of 15,000 men. At first the legionaries were raised in Europe, chiefly in Gaul, but in the second century they were recruited entirely among the indigenous population. Retired soldiers were granted lands and exemptions on the condition that their sons enlisted. In this way towns like Lambessa, half military, half commercial, grew up. The actual number of emigrants from Italy was small; with her declining population she had no emigrants to send. 


\section{Timgad}

There is, therefore, reason to believe that the inhabitants of such cities as Timgad were not to any appreciable extent colonists from Europe; they were rather Romanized Berbers. The names as they appear in inscriptions corroborate this. They are not Latin, if Latin in form. This point is of great importance in considering not only the nature of the Roman rule in North Africa, but also the history and possibilities of the Berber population. They were Romanized once, they are Arabized to-day; what may they be to-morrow ?

As we stand in the Forum of Timgad to-day, we may reflect that this noble city was built and inhabited by the ancestors of the gabbling native crowd which is holding its market at the gate. Doubtless in their simple minds these robed figures are wondering what in the world we come for. They must be aware that it is not a religious exercise; we have our holy places to which they observe that some of us betake ourselves on Sunday mornings; no Christian marabout lies buried here, and we are therefore not votaries making a pilgrimage. Yet is our conduct not mere levity; we wander about with little books in our hands 


\section{About Algeria}

and are very earnest and sometimes vociferous to our companions. Perhaps the most enlightened native opinion inclines to the belief that we are working a spell or enchantment, it may be for the benefit of our motor-cars, which we bring with us to the gate.

Rome, the great mother, welcomed all to her bosom, and it seems that all were glad to come. Little by little the African townships became Latin or Roman municipalities. Roman citizenship became the ambition and the pride of their inhabitants. No higher honour could be inscribed on a tombstone than Civitatem Romanam consecutus. And the Roman religion helped the process of consolidation. Olympus was no close borough. There was always room for another deity. We know, in fact, that the Romans were ever ready to welcome a fresh cult. It was the political, not the religious attitude of the Christians which brought them within the reach of the law and under the displeasure of the Emperors. So the Berbers' gods were Romanized like themselves. Baal Ammon became Saturnus Augustus. The open sanctuaries gave way to closed temples of classical design. Human sacrifice was aban- 


\section{Timgad}

doned. And the Berbers learnt to raise shrines to the Roman allegorical deities, Concord, Fortune, Peace, and Victory; above all to worship the existing order in the divine person of the Emperor. His personal character had nothing whatever to do with this. The infamous Caracalla was the object of as much veneration as the philosopher saint Marcus Aurelius. At the beginning of the third century Africa gave many of its sons to the purple. Macrinus, who attained it by the murder of Caracalla, was a native of the district of Cæsarea. His successor, Elagabalus, of execrated memory, was the son of a former commandant of the Third Legion. And the Gordians, representing as they did the noblest blood in Rome, the blood of the Gracchi and of Trajan, came to the throne from the proconsulate of Africa. Concerning the younger Gordian Gibbon has left us a memorable sentence, which at once exhibits the antithetical bias of his style, and a certain sly humour of which he was master. "His manners were less pure, but his character was equally amiable with that of his father. Twenty-two acknowledged concubines, and a library of sixty-two 


\section{About Algeria}

thousand volumes attested the variety of his inclinations; and from the productions which he left behind him, it appears that the former as well as the latter were intended for use rather than for ostentation. ${ }^{1}$ The Roman people acknowledged in the features of the younger Gordian the resemblance of Scipio Africanus, recollected with pleasure that his mother was the granddaughter of Antoninus Pius, and rested the public hope on those latent virtues which had hitherto, as they fondly imagined, lain concealed in the luxurious indolence of a private life."

Timgad is situate thirty-four miles to the east of Batna, on the fine modern road which proceeds through the Aurès range to Khenchela and Ain-Beida. You may cover the distance in a motor-car within the hour, and you will pass on the way the ruins of Lambessa. These, however, are scarcely worth the prolonged attention of anyone who is not an archæologist, and such picturesque qualities as they may possess are ruined by the proximity of

1 "By each of his concubines the younger Gordian left three or four children. His literary productions, though less numerous, were by no nutans coniemptible."-Note to Gibbun. 


\section{Timgad}

a huge convict prison. The ordinary sightseer, snatching a few hours between two trains, will hasten on to Timgad. The drive itself is very interesting. The road is undulating and at one point ascends to a considerable altitude, and in its way the scenery is impressive. We traverse a great rolling plain which from end to end is one vast cornfield. There is a bare range of hills to the north, and to the south the Aurès mountains, guardians of the desert, with the snow still, in March, lying among their topmost cedars. At the highest point of the road we meet a driving storm of sleet. We are inclined to resent the general treelessness of the landscape, but much may be forgiven to a corngrowing country, and imagination revels in what must be its glory when the crop is ripe for harvesting. But for its fertility the general contour of the country has a very South African appearance. The soil appears to be "rather light," and, no doubt, nothing but the copious rainfall which the Aurès mountains bring redeems it from the miserable barrenness of the high plateaux to the south of Algiers.

At last you come to Timgad, and you see at 


\section{About Algeria}

a glance that you are face to face with what the Americans call " a big proposition." A whole hill-side is covered with the dry bones of a town-a town of which the top seems to have been sliced off, with here and there groups of columns or an arch or two rising from the dismantled mass.

It has been given to few great towns to spring into being at one leap. The growth of towns is usually that of mundane things in general, a gradual process liable to interference from many exterior influences. But Timgad rose full armed from the fiat of the Emperor, as Athene from the brain of Zeus. Trajan said, "Let there be a city," and there was a city. It was no mushroom growth to serve a temporary purpose. It lasted more or less intact for six hundred years, and but for the hand of destroying man it might have lasted six thousand. This is its dominating note,-its huge, its almost unnecessary solidity. And from the circumstances of its birth it presents a fine example of Roman town-planning. British municipal corporations which are concerned in putting into practice our newborn aspirations in such matters should not 


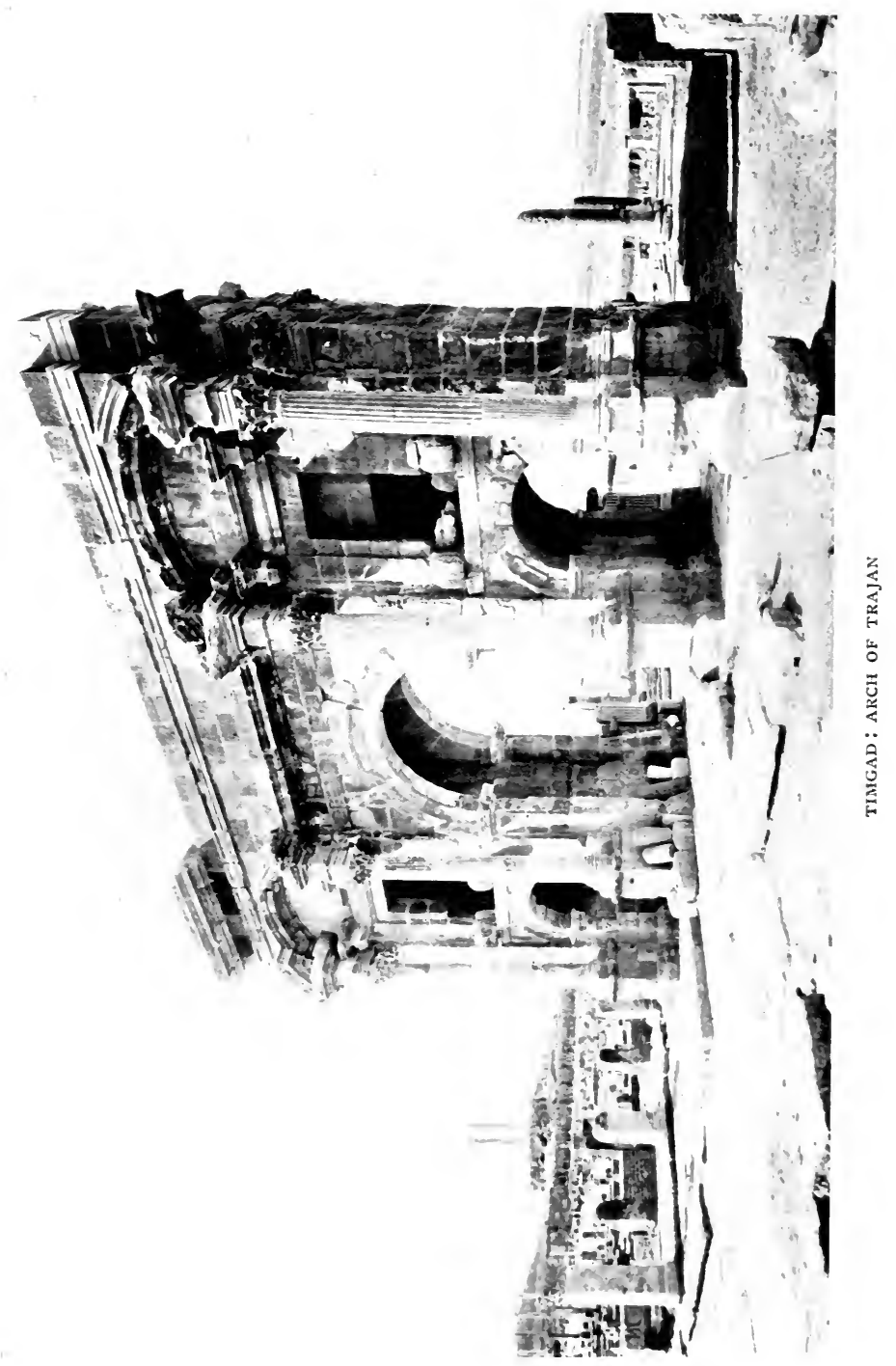




\section{Timgad}

omit to send a deputation to study Timgad on the spot.

But perhaps even with the disquieting possibility of a foreign raid on our shores, denied by our politicians with such emphasis that we are led to believe in its existence, it is not necessary for us to base the plan of our towns on the arrangements of a camp. Such was the underlying plan of Timgad. It was divided, as was the conventional Roman camp, into four parts by two main intersecting streets. That which led from east to west was called decumanus, that which pointed north and south cardo. The former was a portion of the main road from Lambessa to Tebessa, and was doubtless the most used in the town. Its solid pavement shows the wear of wheels, as do the streets of Pompeii. It was naturally at the junction of these streets that the chief buildings were situate. Here is the Forum, with the Theatre behind it and the Municipal Library in front. Looking east from the Forum along the decumanus we see the magnificent Triumphal Arch, the most impressive monument in the town. It is also the best preserved, and thanks to its existence the attention of scholars 


\section{About Algeria}

was called to Timgad in the first instance. With the aid of the excellent and wellillustrated handbook prepared by M. Albert Ballu, Architecte en chef des Monuments historiques de l'Algerie, the visitor will be able to identify and study the whole of the works excavated and restored. Probably most visitors to Timgad will have previously seen Pompeii, and will have some general acquaintance with the arrangements of a Roman town and the nature of its public buildings. Timgad will introduce them to some new features; of its Public Library and the romance of its discovery I shall speak later; it has a remarkably complete series of markets; and the public conveniences behind the Forum will interest those who are concerned about sanitary matters.

However satiated with the wonders of the town itself the visitor should not omit to visit the Museum. Here amid the usual assemblage of mediocre Roman antiquities he will find some mosaic pavements of the highest excellence.

Perhaps we are most of us disposed to be more interested in comparatively trivial matters of decoration and so forth than in the structure and disposal of important edifices. We are 256 


\section{Timgad}

not all architects and town-planners. And here we may take especial delight in a little piece of evidence that even in this frontier city life was not all strenuous. On a stone of the Forum are graven the following words :-

$\begin{array}{ll}\text { VENARI } & \text { LAVARI } \\ \text { LUDERE } & \text { RIDERE } \\ \text { OCCEST } & \text { VIVERE }\end{array}$

"Hunting, bathing, play and laughter,such is life." This symmetrical arrangement of letters is divided by a device consisting of a vase of flowers surmounted by a bird. It speaks to us across the ages a pleasant message ; in such happy human touches Timgad is less rich than Pompeii. And perhaps neither town has anything so delightful as the mosaics found in a bath and a stable at Oued Atmenia between Constantine and Sétif, on the site of a considerable Roman country house. The mosaics in the baths depict various incidents of rural life;hunting scenes in which huntsmen and hounds are named, a garden scene with a lady spinning under a palm tree. One mosaic represents six favourite horses with inscriptions recording their names and qualities; -with Pullentianus is 


\section{About Algeria}

stabled Altus, "unus es ut mons exultas""you have no peer, you leap mountain-high"; Delicatus, "the gentle one," stands alone; Titas, "the giant," shares a manger with Polydoxus, "the glorious"; "vincas non vincas te amamus Polydoxe,"-_"win or lose we love you, Polydoxus." In a corner by himself stands Scholasticus, "the Scholar." In the scene representing a stag-hunt, the master himself appears with his hounds, Fidelis and Castus. Other mosaics represent the farm, the fish-ponds with aquatic plants, the quarters of the huntsmen and the mansionhouse itself. This is a large building with several storeys and numerous windows, surmounted by a balcony or awning. The buildings are roofed with square red tiles, and chimneys appear below the ridge. "This remarkable series of mosaics gives some insight into Roman life and customs in North Africa at the close of the fourth century, and bears striking testimony to the peaceful condition of the country in the declining years of the Empire. Sixteen centuries have passed since Pompeianus presided over this lordly retreat, as a patron of the turf and a lover of sport in all its 


\section{Timgad}

aspects. A few years after his decease the disturbing influence of the invading Vandals must have rendered the maintenance of such an establishment an absolute impossibility, and one can picture the life work of this distinguished Roman neglected, abandoned, and finally becoming a mere hunting-ground for Vandal or Byzantine, Arab or Moor." 1

It has often been suggested that the great prosperity of this region under the Empire was due to a climate superior to that of to-day; that there was in fact a more abundant rainfall and a more equable temperature. The Romans left us no weather statistics (an essentially modern passion), and such evidence as we have appears to be against the theory. The lakes in the province of Constantine were no greater than they are to-day; Roman ruins on their banks attest this. Roman bridges exist here and there throughout the country, and they were not designed to span wider rivers or to resist heavier floods. But this does not settle the matter. It is certain that there was far more timber; the Arab has continually destroyed and he does not plant. The rainfall of

1 Graham, "Roman Africa," 1902, p. 294. 


\section{About Algeria}

to-day is probably less continuous and more uncertain. Yet we cannot believe that the climate is seriously changed. Sallust complains that in Africa both sky and earth have too little water. But the Romans made the best of what there was. The remains of their canals and cisterns are everywhere. In the country to the south of Sétif they dug hundreds of wells, many of which still exist. They barred the course of rivers and created reservoirs. Their extensive works of irrigation are described by Procopius, and appear to be exactly similar to those now in use. Elaborate water-rights existed. A monument found at Lambasba sets forth the number of olives and fruit trees which every farmer possessed and the number of hours of running water to which he was entitled. This system of reckoning a right to water-supply by hours is still in vogue in the island of Madeira, and probably elsewhere. Every effort was made to encourage planting. Exemptions from taxation for a certain number of years were granted to cultivators who planted vines or olives, or grafted the wild olive. Olive oil was exported to Rome in enormous quantities; fragments of jars found in the Tiber 260 


\section{Timgad}

bear the mark of Tubusuctu, a town near Bougie. Such facts go to show that the great prosperity of North Africa was rather due to intelligent use of its resources than to any superiority of those resources. This prosperity seems to have reached its culminating point under the dynasty of Septimius Severus, himself a native of Africa. The fact that he died at York illustrates the extent of his empire. $\mathrm{He}$ and his son Caracalla showered favours on their compatriots, as numerous inscriptions attest.

Arab writers of the seventh century bear ample testimony to the fertility of the territory which had fallen so easily into their hands. From Carthage to Tangier, a thousand miles east and west, the whole country was clothed with olive woods, and it was said that you could walk from village to village beneath a roof of foliage. Therein they have written the condemnation of their successors. A pleasant story is told that the Arab chief who defeated Gregorius expressed his amazement at the richness of the land. "Whence comes this wealth?" he said. A peasant picked up an olive and laid it before the conqueror, saying, 


\section{About Algeria}

"From this." And he added that the Byzantines who had no olives in their country were Africa's best customers.

Timgad is interesting and impressive in itself ; in general as a town surviving through the ages almost untouched at least in its ground plan; and in particular for its several very uncommon and very informing details. But it is even more noteworthy in its suggestiveness. It flashes to us across a yawning chasm a message from a distant past, a message from a civilization not essentially different from our own; a civilization based on ordered liberty and individual effort, on public spirit and service, on private wealth amassed in agricultural and commercial enterprise ; anticipating in its municipal buildings and in the dwellings of its citizens, rich and poor, with sufficient resemblance the conditions of our own life, public and domestic; yet reckoned in the lapse of centuries and the generations of men of an almost incredible remoteness, a remoteness emphasized, as everything is emphasized in this land of staring contrasts, by the hopeless barbarism and neglect which have filled the intervening gulf. Yet there are 


\section{Timgad}

differences. The city stood on the very frontier of the Empire, but it was not built as men build in such situations to-day. Its solidity and magnificence suggest great local pride, the pride of wealthy citizens, who preferred to adorn their own city to spending their money as strangers in the "smart" world of Italy, who chose rather to rule in Africa than to serve in Rome; and they are evidence of provincial prosperity and contentment during that great second century which Gibbon regarded as the happiest period mankind had known. And we cannot suppress our surprise that the very existence of such a town is scarcely known to us from historical sources. If it were not for its ruins very few among scholars would have heard the mean of Thamagudi. In any endeavour to picture to ourselves the Empire as a whole such a fact is of great significance. And with such throbbing life at its extremities it is difficult to regard the heart as unsound.

The contemplation of such a town as Timgad helps us to realize the compelling force of Rome's unequalled genius. On this remote frontier of her Empire we may trace to-day 263 


\section{About Algeria}

the same motives in building-all that meets the eye-which were dominant in the mother city. "In every branch of art, whether in sculpture, painting as displayed in the decorative forms of mosaic, or in architectural design, the same monumental remains await our coming; the basilica, the amphitheatre, the triumphal arch; the aqueduct and the fountain; the bridge, the temple and the tomb. They stand before us as examples of dignity of conception, unerringness of line, justness of proportion, fitness of purpose and soundness of construction." 1 We see nothing but the remains of these buildings, but we may assume from them that in more vital matters,in law, in public life, in the family and in individual habits the pattern set by the capital was equally predominant. And we may further reflect that Rome's influence was not merely geographical in extent; it did not perish with her fall. Modern civilization is essentially Roman. The Roman's "laws, his language, his literature, his festivals, even his calendar, keep their ground." The Roman tradition is ingrained in our minds and conduct, and in

1 Graham, "Roman Africa," p. 304. 


\section{Timgad}

small things as in great we unconsciously and as a matter of course pursue the Roman model. And it may be that the desperate struggle for the hegemony of Europe-and Africa-now proceeding is heralding the evolution of another Empire on Roman lines. 


\section{$X I-A \quad P U B L I C \quad L I B R A R r$}

A romantic find-A municipal library of the third century-A Roman Carnegie-Christian Africa-The Donatists-Genseric the Vandal - Justinian-Timgad and Pompeii.

"They say that scholars thronged the column'd court; To drain reluctant learning's cup they sought ;

Lo! all to utter nothingness have passed, Alike for book and scholar life is short."

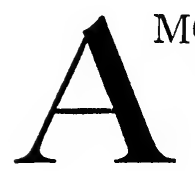

MONG the buildings unearthed at Timgad there is one which, from its nature and the fact that it is unique, or almost unique, is especially interesting, and merits particular attention. The learned world has long been aware that the Public Library, which is a comparatively recent addition to most of our own towns, was a Roman institution. The allusions of Latin authors tell us so much; there were twentyeight public libraries at Rome in the fourth century; and we gather from inscriptions that there is nothing original about Mr. Carnegie, except the extent of his munificence. The 266 


\title{
A Public Library
}

public libraries of provincial cities were often due to the liberality of wealthy citizens, and once established they were frequently enriched by the gifts and bequests of others. By a succession of fortunate accidents, which happily illustrate the romantic side of excavation, the Public Library of Timgad has been found and identified beyond question. This fact in itself gives a very special distinction to the ruins.

In 190I, in clearing a block of buildings in the Cardo, not far from the principal gate of the Forum, the nature of which was unknown, the excavators found a broken portion of an inscription. It seemed to refer to the dedication of the building as a public institution, but threw no light on its nature. It was vaguely considered to be a school or salle de réunion. The mutilated inscription was as follows :-

\author{
VINTIANI FLAVI RO \\ MENTO SUO REIPUBLICAE \\ SIUM PATRIAE SUAE LE \\ EX IS CCCC MIL. NUM \\ CTUM EST
}




\section{About Algeria}

This merely indicated that the building had been erected at a cost of 400,000 sesterces, or about $£ 4000$, as a result of a legacy of one Q. F. Ro-

In 1904, in the course of some digging in a neighbouring house, a little to the north, a second fragment of this inscription was found. It fitted exactly to the left-hand side of the former fragment, and read as follows :-

\section{TE M IVLI $Q$ \\ AD TESTA \\ VGADEN \\ OTHECAE}

A PERFE

This was very tantalizing; it did not explain the exact object of the building, but it proved that it could only be something of which the Latin name ended in the letters oтheca. Now in the Latin language there are five such words;-pinacotbeca, a picture gallery; apotbeca, a wine-shop; oporotbeca, a store-room for fruit; zotbeca, an apartment with niches for statuary; bibliotbeca, a library. Of these the only words at all applicable were the two last. 


\section{A Public Library}

Between them the usual controversy of savants arose; much could be said, and was said, on either side. From the first the advocates of the library seemed to have the best of it. They based their arguments on the nature of the building. It occupies with its dependencies a rectangular space measuring 77 by 80 feet. Its principal front, facing east, is composed of a portico in the form of a letter $U$ sustained by twelve columns of white calcareous stone, framing a court which opens on to the street. On each side of the portico was an entrance to two partially open chambers, bounded by two side streets leading to the Cardo. Behind these was a great central hall with a room on either side of it, each having a niche at the further end. The termination of the hall was of semicircular form; on each side of it were six detached columns of white marble, corresponding to the same number of pilasters in the wall, between each side pair of which was a square recess. In the middle of the semicircle was a larger and deeper recess, which doubtless contained a statue. The advocates of the zotbeca theory urged that the main purpose of the building was to be the shrine of 269 


\section{About Algeria}

an important statue, bequeathed by Quintianus Flavus Ro- to his mother city. The case for a library seemed stronger and more attractive. It was suggested that the rectangular recesses were receptacles for volumes or rolls of papyrus, and that benches or steps which led up to them from the centre of the building were intended to serve as seats for readers. The detached columns were considered to have supported two upper galleries containing a second set of bookcases, while the great niche at the end was an architectural feature, doubtless containing a statue of Minerva. The head of such a statue was found in the neighbourhood. The two side rooms were held to be further store-rooms for books; one of them, having a door into the street, perhaps reserved for the use of the librarian. There are indications of recesses in their walls also. The great hall, it was observed, was exceptionally well lighted by a skylight in the vaulted roof of its semicircular portion, and therefore very suitable for reading.

The question was settled in 1906,-on the 17th of March, at five p.m.,-as M. Ballu records with exulting precision. In making an 

and

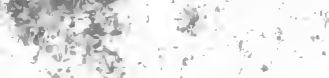




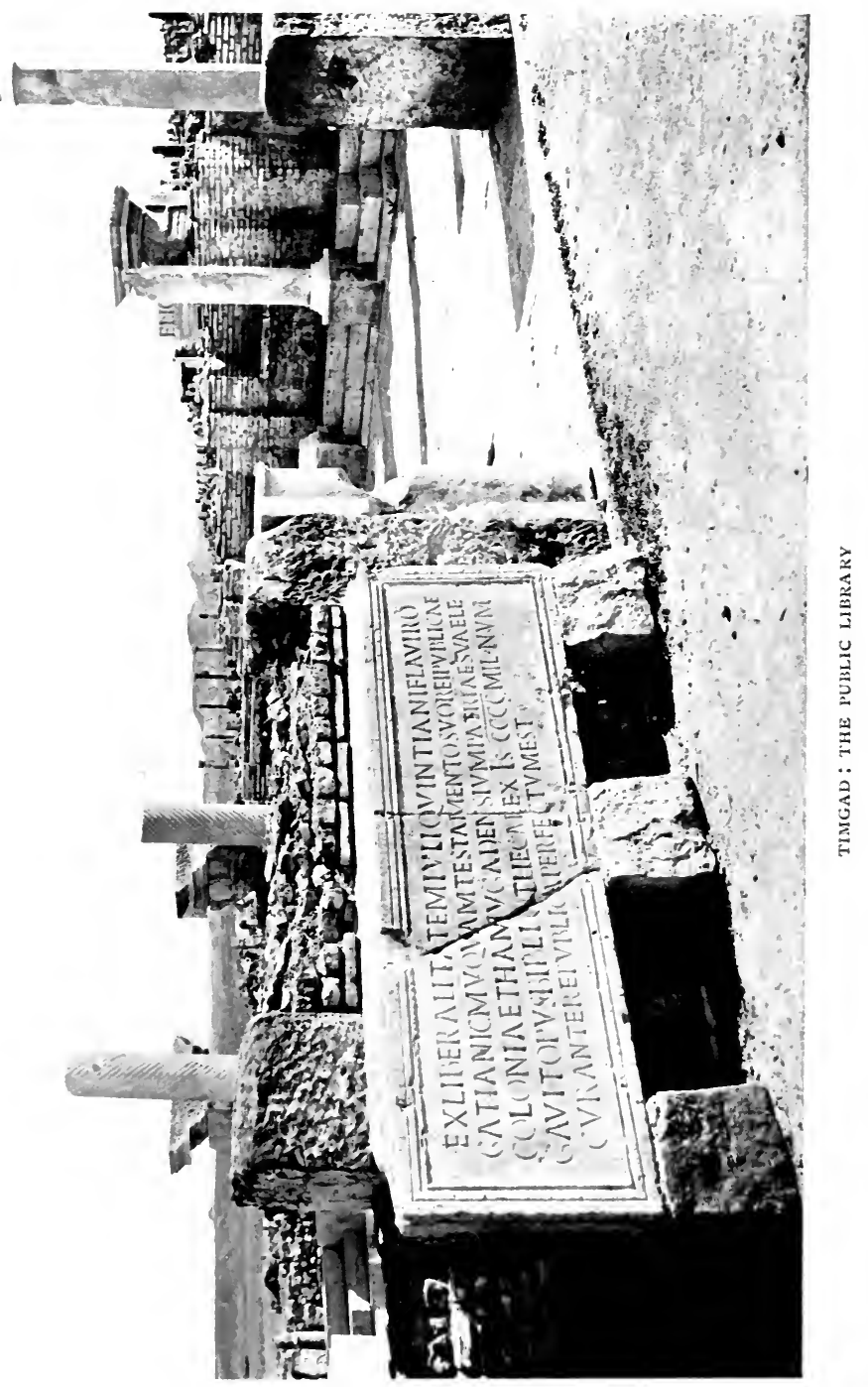




\section{A Public Library}

experimental hole beside the Cardo, a workman drove his pick against a fragment of inscribed stone, which proved to be the missing piece containing the first portion of the inscription. The supporters of the library theory were right. The words on the stone were as follows:-

\section{EX LIBERALITA \\ GATIANI. C.M.V. QV \\ COLONIAE THAM \\ GAVIT OPUS BIBLI \\ CVRANTE REPVBLIC}

"There is no necessity," says M. Ballu, " to tell with what joy we received a telegram announcing this discovery. It was the consecration of our suppositions, certitude succeeding to probabilities, which had nevertheless not left much room for doubt. It was, above all, a revelation of the arrangements of those ancient Roman libraries of which so many Latin authors speak; but as to the construction of which we possessed no evidence."

The full inscription is to the following effect :-

"Out of the funds bequeathed by Marcus 


\section{About Algeria}

Julius Quintianus Flavus Rogatianus, of senatorial memory, by his will to the colony of Thamagudi his mother city, the erection of a library has been completed at a cost of 400,000 sesterces, under the direction of the city authority."

The name of this benefactor is otherwise unknown. The building which bears it was well built of fine materials, with marble columns, and marble veneerings to the walls, of which copious fragments have been found. Among these fragments are some of particularly fine coloured marbles which perhaps adorned the niche in which stood the statue of the presiding goddess. The pavement, which remains, is of a very finished type.

It is not possible to assign a precise date to the building, but it is considered to be of the third century. It doubtless took the place of an insula, or large private house isolated by four streets, of which other examples line the Cardo. It occupies a rather larger space than these houses; the semicircular portion of the hall extends into the back street, and on the south side the normal width of the street is reduced by it. 


\section{A Public Library}

A somewhat fanciful calculation has been made of the number of books which the library might contain; and the figure of 6800 for the interior hall, and 16,200 for the other chambers, has been arrived at. This seems to be carrying reconstitution a little too far.

There are some to whom Timgad is the most interesting place in Algeria; to many antiquaries, and perhaps to many of that large class which is concerned one way or another about all that appertains to books, this Public Library, identified beyond all cavil by such happy fortune, will be Timgad's most interesting building.

It may be noted that about the time of the discovery of this library, the Austrian Archæological Institute, in the course of excavations on the site of Ephesus, found a building in many respects similar to this one. An inscription in Greek and Latin left no doubt that it was a library. Its form is rectangular instead of semicircular, but it possesses a niche at the end for the statue of Minerva, and the walls contain similar recesses for the reception of books. It has a portico in front, but lacks the side chambers which occur at Timgad. 


\section{About Algeria}

The interest of Timgad, and its part in illustrating history, are not exhausted by a view of those buildings of the second and third centuries which mark the period of its greatness. If in the troublous times which followed it suffered, yet it played a part in African affairs until the Arab conquest. To the understanding of its monuments some slight acquaintance with events is necessary.

During the latter part of the third century two processes were at work in Africa, the formation of great estates out of the ruin of small proprietors, and the spread of Christianity. The two were not unconnected. The new religion attracted all who were dissatisfied with the existing order. It ran like a flame through Barbary. It produced three great men: Tertullian in the second century, Cyprian in the third, and Augustine in the fourth. But the movement throughout was more political and social than religious. It was based among the Berber population rather on discontent than conviction. With the official recognition of Christianity under Constantine its attraction as a symbol of revolt disappeared. A substitute was found in schism. The curious inter- 


\section{A Public Library}

workings of finance, politics and religion have never been more fully illustrated. The misery of the cultivators under the wretched financial system of Rome has not been accorded its due weight as a factor in the most extraordinary event in history, the conversion of the Empire to Christianity.

Even under Constantine, the first Christian Emperor, the schism of the Donatists, destined to ruin Roman Africa, grew to a head. It arose from a personal dispute as to the position of a bishop named Donatus ; if there were any differences on points of doctrine they were insignificant. But it plunged Africa into anarchy for centuries; it laid open the way to the invasion of the Vandals, and was extinguished only with Christianity itself.

Timgad was the very focus of Donatist agitation. Its bishops took a leading part; of one of them Augustine says that for ten years Africa trembled beneath his yoke. To this century perhaps belong the ruins of several Christian churches unearthed in the city. The schism was not bounded by the arguments of doctors. It extended to the 


\section{About Algeria}

pillage of estates and the sack of cities. The wild tribes of the Aurès and other mountain districts which had never completely owned the sovereignty of Rome made common cause with the schismatics. And Roman Africa was ruined. Then came the Vandals.

The historian Gibbon, who rises to his highest flights in the consideration of Christianity and its heresies, has sketched the Donatist pretensions in immortal words : " $\mathrm{Ex}$ cluded from the civil and religious communion of mankind, they boldly excommunicated the rest of mankind. They asserted with confidence, and almost with exultation, that the apostolical succession was interrupted; that all the bishops of Europe and Asia were infected by the contagion of guilt and schism; and that the prerogatives of the catholic church were confined to the chosen portion of the African believers, who alone had preserved inviolate the integrity of their faith and discipline. This rigid theory was supported by the most uncharitable conduct. Whenever they acquired a proselyte, even from the distant provinces of the East, they carefully repeated the sacred rites of baptism and ordination; 


\section{A Public Library}

as they rejected the validity of those which he had already received from the hands of heretics and schismatics. Bishops, virgins, and even spotless infants, were subjected to the disgrace of a public penance before they could be admitted to the communion of the Donatists. If they obtained possession of a church which had been used by their catholic adversaries, they purified the unhallowed building with the same jealous care which a temple of idols might have required. They washed the pavement, scraped the walls, burnt the altar, which was commonly of wood, melted the consecrated plate, and cast the holy eucharist to the dogs, with every circumstance of ignominy which could provoke and perpetuate the animosity of religious factions." Such an account would almost describe proceedings of religious fanatics at a date much nearer our own age. But the fervour to which the Donatist schism gave birth produced under the African sun remarkable developments. "The rage of the Donatists was inflamed by a frenzy of a very extraordinary kind; and which, if it really prevailed amongst them in so extravagant a degree, cannot surely be paralleled in any 


\section{About Algeria}

country or in any age. Many of these fanatics were possessed with the horror of life and the desire of martyrdom; and they deemed it of little moment by what means, or by what hands they perished, if their conduct was sanctified by the intention of devoting themselves to the glory of the true faith, and the hope of eternal happiness." They would disturb worshippers, waylay travellers, or insult courts of justice, in the hope of achieving martyrdom. Failing other resources, they would cast themselves headlong from some lofty rock. "In the actions of these desperate enthusiasts, who were admired by one party as the martyrs of God, and abhorred by the other as the victims of Satan, an impartial philosopher may discover the influence, and the last abuse, of that inflexible spirit which was originally derived from the character and principles of the Jewish nation."

Genseric, King of the Vandals, landed in Africa from Spain in A.D. 429. Born a Catholic, he embraced the Arian heresy, and made common cause with the African Donatists. He swept through Barbary, an easy conqueror. His fleets ravaged the coasts of Italy and Sicily. 


\section{A Public Library}

In A.D. 455 he sacked Rome. For a hundred years the rough Northmen held the fertile provinces. They rased the fortifications, but did not overthrow the Roman cities; they rather succumbed to their luxury. They did not destroy, but they constructed nothing. They had no thought of substituting their own institutions for those of the conquered races. They considered themselves merely a garrison, for which the country must provide subsistence. Their decadence commenced with the death of their leader.

In the early part of the sixth century Byzantium set himself to take up the mantle which Rome had let fall. The great Justinian determined to make good his claim to all the former possessions of the Empire. The Vandals were in no condition to offer a vigorous resistance. The native population was everywhere in revolt. The tribes of the Aurès descended from their mountains and sacked the fair cities which had been raised under the protection of the Third Legion-Tebessa, Bagai, Lambessa, and Timgad. Belisarius, the Byzantine general, landed in Tripoli in A.D. 533, and, marching rapidly westward, met with little 


\section{About Algeria}

resistance. In a few years a great part of the corn-growing districts was brought under effective control. All the ports were held by Byzantine garrisons. Barbary was to experience an Indian summer.

The first care of the Greeks was to build a series of fortresses to hold in check the tribes of mountain and desert which for generations had been acquiring greater boldness in war and pillage. Remains of such forts are all over the country. There is one at Timgad, situate about I50 yards from the Southern Baths. It is a great quadrilateral flanked with square towers, and covering more than 7000 square yards. It is extraordinarily solid in construction, the walls being nine feet thick. But it is at Tebessa that the most perfect example of Byzantine fortification exists. The enceinte encloses the Arab town, and to put it into a state of defence the French have only had to execute a few repairs. For these hastily constructed fortresses any materials which came to hand were used. Into the solid walls faced with square blocks were thrown the debris of private houses, the friezes of temples, the statues of the gods. 


\section{A Public Library}

What the Vandal had spared, the Berber and the Byzantine between them made an end of.

Under the shelter of these fortified places a neo-Roman civilization budded again. The great proprietors and the wealthy financiers of the later Empire had disappeared. Their place was taken by the Church. The bishops occupied themselves with business of every description, political, financial, administrative, and even military. Vast sums were spent in the construction of great basilicas and monasteries, the ruins of which may be seen at Timgad and Tebessa to-day. To this period doubtless belongs the huge building, basilica and monastery, to the west of Timgad. It covers a space of not less than 20,000 square yards. The basilica is 200 feet long and 70 feet wide, and is preceded by a court-yard of the same size as itself. It is built chiefly of stones taken from the neighbouring pagan temples, which must have been already in ruin at the time of its erection. If, as some suppose, these great churches were built originally during the fourth and fifth centuries, before the Vandal invasion, there can be little doubt that they 


\section{About Algeria}

were rebuilt with modifications and enlargements during the Byzantine period.

The domination of the Church did not make for the prosperity or security of the people. The great dreams of Justinian were never realized ; his enterprise from the very beginning had in it the seeds of decay. The rapacity of the ecclesiastics at least equalled that of the former Treasury officials; the husbandmen were plunged in a condition of abject poverty ; the persecution of schismatics decimated the population. Native insurrections, mutinies of troops, sullen detestation of the people prepared the way for the easy fall of the Byzantine administration before the invading Arabs of the next century.

It is natural to compare Timgad with Pompeii, and the comparison has often been made. But beyond the fact that both were towns of the Roman Empire, and that the ruins of both have been preserved to an extent unparalleled elsewhere, they have no great resemblance. It happened to me, as probably it has happened to few, two or three weeks after leaving Timgad, while the memory of it was fresh, to stand once again in the Forum of 282 


\section{A Public Library}

Pompeii. I recalled their different conditions. They were not contemporary; Pompeii was destroyed before Timgad was built; Pompeii, rather Greek than Roman in origin, was a pleasure town of the first century, which, after damage by an earthquake at the zenith of its prosperity, was overwhelmed by ashes from Vesuvius; Timgad was a military and commercial town of the second and third centuries, ruined first by religious faction and financial breakdown, and finally overthrown of set purpose by a horde of mountaineers. To compare them is like comparing the Tunbridge Wells of the eighteenth century with the Pretoria of the twentieth. The contrasts their ruins present are those we should expect. Timgad is more solid and more serious; its public buildings are finer; its main streets are more important; and there is nothing at Pompeii to compare with the magnificent arch of Trajan. But Pompeii is richer in minor matters, in all the illuminating incidents of private life; its chief interest lies in its wonderful houses, and in the almost miraculous preservation of much of their interior decoration. And their situations accord with their peculiarities. Timgad 


\section{About Algeria}

lies on a bare hill-side, far from the habitations of man; Pompeii hard by the lovely bay of Sorrento, in one of the fairest landscapes of Italy. The cities are not rivals; they supplement each other; and those of us to whom a study of what was before is one of the chief interests of life may be grateful that we have so much of both. 


\section{XII-THE ROAD THROUGH}

\section{KHABYLIA}

Sétif-The Chabet pass-A fishless river-A lovely coast-BougieKhabylia-Greek types-Fort National.

"A rough laborious people, there, Not only give the dreadful Alps to smile, And press their culture on retiring snows, But, to firm order trained and patient war, They likewise know, beyond the nerve remiss Of mercenary force, how to defend The tasteful little their hard toil has earned."

Thomson.

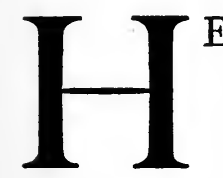

E who returns by motor-car from Biskra to Algiers may avoid the detour via Constantine by taking the new direct road from Batna to Sétif, a distance of 132 kilometres. It ascends to an altitude of over 5000 feet, and in winter is sometimes blocked by snow. But this is not likely to be a frequent trouble. Whichever way he comes, direct or roundabout, by road or rail, the traveller must 


\section{About Algeria}

make Sétif his point. If he omits to take the road from Sétif to Bougie, through the Chabet pass, a distance of II 3 kilometres, he will have no idea of what Algeria is capable of in the way of mountain scenery.

There is a distinct tendency among Englishmen to-day to revolt against the domination of the guide-book. With our ancient constitution in the melting-pot, and our most cherished national convictions openly contested, it is hardly surprising that even the revered name of Murray has failed to maintain its authority. There are abandoned men who openly flout it, who want to see nothing of the things that ought to be seen, to know none of the things that ought to be known. The reaction was inevitable. Murray and Baedeker and the like set poor human weakness an impossible ideal. They direct us as if we were an army of invasion; they map out our operations day by day and hour by hour with a ruthless precision. Has anyone ever carried through the programme of How to spend ten days in Rome, and survived to boast of it ?

Wherefore in our iconoclastic age there are 286 


\section{The Road through Khabylia}

men to whom the guide-book's double star is but a danger signal. Let me implore them to waive their prejudices as far at least as the Chabet pass is concerned. If much be-praised it is still quite un-hackneyed; and it is magnificent. And they may steal a march on the enemy. The guide-books, as far as Algeria is concerned, have not discovered the motor-car. They direct you to hire a carriage at Sétif, to sleep at a roadside inn, and to lumber into Bougie at the close of the second day. We have changed all that. We take a car at Sétif after déjeuner, and loitering by the way we yet reach Bougie in time to stroll round the town before dinner. So we have a day in hand. But let us haste to do it before a revised edition comes out.

The plateau of which Sétif may be considered the centre lies at a high altitude, and as the sea is no great distance off, we may perceive from a glance at the map that there must be a more or less rapid landfall towards it. Such conditions commonly produce a picturesque coast-line. Here we have more than this. The plain is supported by a very abrupt range of mountains rising to twice its height, - 


\section{About Algeria}

the peaks to 6000 and 7000 feet. Such a range must either be crossed by a high pass, or it may be that we may find an outlet where a mountain stream, taking advantage perhaps of a rift caused by a natural convulsion, has worn for itself a passage. Such a passage is the gorge of Chabet-el-Akhira.

From Sétif, most hideous of modern French towns, the road leads northward for some distance through an uninteresting corn-growing country. After a few miles the surface becomes more broken, Khabyle villages begin to appear on neighbouring hill-tops, and Khabyle gardens are rich in apricot blossom. We cross a chain of hills running east and west, from the summit of which we obtain a splendid view of the mountain range which we are about to penetrate. We descend rapidly to the stream which is to be our companion, and at a distance of fifty-three kilometres from Sétif reach Kherrata, at the mouth of the pass. Here is the half-way house where the carriage-folk of former days were wont to pass the night. It lies in a cool upland valley at the foot of bare stony hills which might be in Wales or Cumberland. It is market-day in the village, and the 


\section{The Road through Khabylia}

street is crowded with Khabyles,-as ragged and dirty a crowd as you may see in county Galway. Their Arab dress looks curiously incongruous with such very northern surroundings.

Immediately beyond Kherrata the road enters the gorge with a dramatic suddenness. It descends rapidly by the side of the stream which here becomes a torrent. The valley contracts and soon grows so narrow that the road has to be bored, as it were, through overhanging cliffs, or borne on arches above the river. There are many kinds of gorges; the least interesting perhaps are those which run directly between unbroken cliffs. This is of the finest kind. Its turns are rapid. It has numerous lateral valleys which break its almost perpendicular sides into seeming pinnacles of rock. One looks almost directly upwards to peaks five and six thousand feet high. Even where the road is carried several hundred feet above the river you may toss a stone and strike the opposite cliff. It is said that before the French road-makers came not even an Arab could pass the gorge on foot. Great caves appear on the mountain sides, the haunt of $\mathbf{T}$ 289 


\section{About Algeria}

innumerable pigeons; monkeys are generally to be seen, but on market-days the exceptional traffic scares them to seclusion. Here and there waterfalls descend from the tributary gorges, and rapidly swell the turbid stream.

Even the all-pervading Roman seems to have found this gorge too much for him. Yet it is not easy to discover an endroit which has not echoed to the tramp of the legions. Mr. Belloc ${ }^{1}$ tells a delightful story of a French general who, filled with pride at having conducted his troops through an almost impossible defile, sent a party to inscribe a record of the achievement on the face of a cliff. The men came back to say that there appeared to be lettering on the cliff already. On examination this proved to be "Legio III Augusta."

The actual gorge is about four miles long. The valley then gradually widens, the hills become rather less abrupt, their sides are clothed with ample vegetation, chiefly forests of cork and oak trees, and the lateral valleys grow larger, in due proportion to the general scheme. We pass from the thrilling sensations of the unique defile into a mountain

1 "Esto Perpetua." London, 1906. 


\section{The Road through Khabylia}

valley of great beauty, but less unusual in character.

It happened that I offered a seat in my car to a gentleman whose party were inconveniently crowded in their own. I began by doing the unpardonable thing; deceived by certain guttural syllables, I said, "Are you a German?" He replied : "No! thank God, I am Dutch." And my heart was glad within me, for the Dutchman is our brother, and our friend; perhaps because we have fought him over and over again, and sometimes we have beaten him, and sometimes he us. We have had, as far as I am aware, no such pleasant relations with the German; perhaps if we had fought him for a century or two we should appreciate his good qualities. In spite of this inauspicious beginning, I soon found points in common with my chance companion. We both knew many lands; especially we both knew the same places and the same men in Norway. My Dutchman loved Norway as I love it, and knew it better. Our points of view were different. His to range far and wide, to sip as a bee winging from flower to flower the varied beauties of fjord and fell, of 


\section{About Algeria}

fond and brae; mine to mark the rise and fall of one much-studied river, chained as a galleyslave to my angle.

So we played the pretty and seductive game of resemblances. Here in this fierce African landscape we contrived to see Bratlandsdal, here Sundal, here the smoothened rock-faces of Naerodalsosen. Lower down where a vast amphitheatre of hills guarded the meeting of two waters we saw the Pyrenees. But the while I was hugging to myself a secret study of which my comrade recked nothing. Even as a man may travel by train, and mark a country, and consider within himself how he would ride over it to hounds;-so was I noting the pools and streams of the river, muddy as a glacier-fed river may be in a hot July, and judging where the fish would be like to lie, and how I should put the fly to them. A very pretty pastime, but clouded by the knowledge that no fish that is a fish, not even a wee trout, may live in these waters. They contain calcareous salts, or something unpleasant, which no fish of the royal race will stand. There are hopes of acclimatizing tench; but who can wax warm at the prospect? 


\section{The Road through Khabylia}

Yet was this to look upon a real river, the finest river (with all respect to the Nile and the Zambesi; I speak as an angler) that I have seen in Africa; a fair succession of pool and stream, - of pools running swiftly beneath steep banks and shelving shores, of streams just steep enough to make the pools holding. The pity of it! From end to end Africa has an air of being unfinished and illdesigned; there is always something wanting to its completeness; in some ways it is too big, in others too small; it lacks water, or it has too much; and things are seldom what they seem, -when you descry a distant lake it is generally the mirage; wherefore a salmon river without salmon falls quite within the natural order of African things.

So on through the broadening valley, with glimpses of azure sea ahead, and soaring mountains, clad with primeval forest, all around. The road, well engineered,-that goes without saying, -is much cut up by the heavy traffic to and from certain mining enterprises in the hills. One iron-ore mine,the property of an English company, I hear with national pride,- - on the opposite side of 


\section{About Algeria}

the valley has a little railway and a little port of its own; and two vessels, hovering suspiciously in the offing, are not corsairs, but intent on a lawful freight. But here, as everywhere, the authorities are busy in making the road smooth for the motor-car, and the repairers and a steam-roller are at work. The car is not yet a familiar object to man and beast. A mule bearing a native bolts at our approach, and unseats its rider. We call to the chauffeur to stop. He replies, "Mais, ce n'est qu'un Khabyle"; in which I recognize a common colonial note. We look round to see the mule caught and the rider up again, and go on happily.

The long descent comes to an end at length, and at a point about twenty-three miles short of Bougie we reach the sea. The coast-lands here consist of a series of semicircular plains, divided by great spurs which run northward from the main range, and form capes. Across these flat and highly cultivated plains our road lies where it may with Algerian directness, but rises to dizzy heights by zigzags to surmount the precipitous headlands which once or twice bar its progress. The contour of this 


\section{The Road through Khabylia}

variable and rocky coast is eminently picturesque, the views of sea and mountain of infinite variety. And afar the dazzling whiteness of Bougie stretching upwards from its harbour among the olive groves invites us. The level lands appear to be of great fertility; amid great fields of corn and vine pleasant and prosperous-looking country houses stand, girt about with fruit trees,-figs, apricots and peaches. In some places the cultivation is carried almost to high-water mark, in others a sward of fine turf seems to meet the sand.

Bougie, rising on the steep hill-side behind its protecting cape, looks almost southward, and its bay appears to it as a land-locked lake. On the southern shore stand the majestic mountains through which we have bored our way from Sétif, with plenty of snow on this, their northern face, crowning their copious forests of cedar and pine. Few seaports have such a romantic outlook. It cannot be doubted that this coast is destined some day to be a second and grander Riviera, and if another Lord Brougham sets to work to create another Cannes, it is perhaps in the neighbourhood of Bougie that he will place it. Apart from its 


\section{About Algeria}

own abounding attractions, it is surrounded east and south and west by incomparable scenery. Its charms are already beginning to be known. It is a meeting-place of excellent roads, and the motor-car has rendered it easy of access. Its comfortable hotel is always full, and is making haste to enlarge itself. Let Bougie start a casino and band, and it will begin to have a season. And in my mind's eye I can see golf-links along the shore of the bay, para thina thalasses, where the sea-sand meets the verdure.

There is something theatrical about Bougie's scenery. Stand on the shore in front of the old Saracen gateway and look upwards at the background of the town rising tier on tier, a town of brilliant white houses gay with the dazzling purple of the bougainvillea, with the bastions of an apparently cardboard fort to the right, and a suggestion of ruined castles to the left, and you may fancy that you are in the stalls at the Opera, and that a chorus of fishergirls will shortly appear and point to a pirate in the offing.

Bougie, exporter of wax, is said to have given its name to the candle. And it has other 


\section{The Road through Khabylia}

historical associations. Its story is not very dissimilar from that of many ports on this coast. Phœnician traders, Roman colonists, Vandal invaders, Byzantines, Berbers, Arabs, Spaniards and Turks, -all have had their day, and many of them have left their impress. Traces of the Roman wall exist; the Saracenic enceinte, enclosing a space seven times the size of that which lies within the present fortifications, is still marked by ruined towers which rise picturesquely among the olive trees. In the matter of piracy Bougie followed the example set by Algiers with great zeal and success. So troublesome were its corsairs to Spain that in 1508 Ferdinand V was goaded to action, and sent a fleet of fourteen ships under Don Pedro Navarro to take possession of it; and the Spaniards held it for nearly forty years. But the failure of the expedition of Charles $V$ against Algiers in 1545 put great courage into the Algerians. They attacked the castle on the harbour and the citadel on the heights with an overwhelming force. The governor, Don Alonzo de Peralta, seeing resistance hopeless, and anxious to save the lives of his garrison and its women and children, 


\section{About Algeria}

surrendered the town on condition that all the Spaniards within the walls should be allowed to depart, and that ships should be furnished to carry them to Spain. The Emperor, doubtless still smarting under his defeat, did not take this fresh reverse in good part and condemned the unfortunate governor to lose his head. Thenceforth until the French invasion Bougie was held by a small Turkish garrison, and the town, which is said to have contained in its palmy days a population of 100,000 , fell into decay. It is now once again on the up-grade of prosperity.

From Bougie it is possible to proceed to Algiers by steamer, or by train, but the traveller who has reached it by motor-car from Sétif should on no account miss the opportunity to drive through Khabylia, the beautiful and interesting mountain district which lies between the snowy Djurjura and the sea. The distance via Fort National to Tizi-Ouzou, on the western side of the upland country, whence Algiers may be reached by train in three hours, is about 150 miles. A magnificent new road breasts the mountain wall which confines the valley above Bougie, and leads with intermin- 


\section{The Road through Khabylia}

able curves and zigzags through forest and cultivated land, through heath and downland turf, to a chilly height of nearly 5000 feet.

The configuration of this country, the foothills of the Djurjura, is peculiar. A series of slopes confines a wealth of valleys great and small, into which project knife-edges, commonly crowned at their termination with castle-like rocks. The Djurjura range protects these valleys from the hot and drying winds of the desert, and its snows supply copious torrents and a moist atmosphere. The country affords a very striking contrast to the typical arid upland of Algeria. In such conditions we naturally find a very luxuriant vegetation. Cedars, oaks, olives, figs and vines flourish exceedingly, and beneath them the sward suggests a more northern land. Africa maintains its character as the continent of surprises.

On every vantage-point which offers possibilities of defence, especially on the narrow ridges near their final crests, stand Khabyle villages, commanding both slopes. In such a situation there is seldom water to be found; and it is the perpetual task of the women (who 


\section{About Algeria}

are unveiled) to carry it to their homes from the cascades on the neighbouring hills. The villages are composed of small stone houses densely crowded together, roofed with tiles, the lines of the roofs being generally parallel, which gives them a curiously symmetrical appearance. Their dirt and squalor is indescribable.

A strange people these Khabyles:-a white race, or at least not more tanned than many dwellers on the northern shore of the Mediterranean, and recalling in physique an Italian type; ardent cultivators and determined fighters in defence; with a long-established and intelligent system of local self-government, and elaborate institutions, public and domestic; yet confessing the faith, and wearing the garb of the Arab, with whom they have nothing else in common. Till the French came they had never owned a master. Before $187 \mathrm{I}$ they had maintained and been permitted a modified independence; but to their own undoing they took a leading part in the rising of that year, and committed many savage murders and outrages on helpless French colonists. Their subjugation followed as a matter of course; 


\section{The Road through Khabylia}

many of their lands were forfeited, and they became the servants of the new lords.

There is quite a large and serious literature dealing with the peculiar habits and customs of the Khabyles after the thorough and logical, if somewhat dull, manner of French writers. From an artistic point of view an Englishman, Mr. Edgar Barclay, has made Khabylia his own. His "Mountain Life in Algeria" (London, I882) is a description of the country as it appears to an artist and a scholar. The common eye is filled with the non-essential details of personal uncleanliness and the squalor of seldom-washed garments; the artist looks below these to the inherent qualities of form. In the troops of girls filling their pitchers at the waterfall or bearing them in line to their village, in the wood-cutter and the shepherd, Mr. Barclay has seen again the types of ancient Greece when the world was young.

Fort National crowns a common ridge running east and west between the two chief valleys of Khabylia. It looks southward to the great snowy rampart of the Djurjura, here evident in all its glory. The road westward follows the ridge to its extremity and then descends 


\section{About Algeria}

to the vale in a series of abrupt and, to the motorist, rather alarming zigzags. And so we come to Tizi-Ouzou and Algiers.

The magic carpet of our day has borne us in a brief space through landscapes of astonishing contrast; through territories which are a storehouse of conflicting yet commingled human interests; across the vast cornfields which suggest man's taming of a newly discovered continent, to the siege-scarred cliffs of Constantine, the awe-inspiring immensity of the Sahara, the speaking ruins of the Roman marches, the Alpine gorges and sylvan sweetness of the Mediterranean shore. Perhaps nowhere within so small a compass is the history of twenty centuries writ so large, nowhere the evidence of man's struggles, and especially of his failures, more plain for him who runs to read. 
INDEX 
i

$\therefore$ 


\section{$I N D E X$}

Ain-Beida, 252

Algiers, 2 I seq., 48 seq., 97,

El-Eubbad, I 7 I

El-Guerrah, I 78

103, I04 seq., I 24 seq., 298, 302

Atlas, the Lesser, 28

Aurès range, the, I 85,197 , 202, 205, 208, 245, 252

Bagai, 279

Batna, r 97, r 98, 201, 242, 248, 252, 285

Biskra, 43, 197, 198, 203 seq., 247

Blidah, 88, I 33, I 45

Bône, 72, 184

Boufarik, 89

Bougie, 56, I 7 1, 287, 294 seq.

Bou-Saida, 247

Chabet-el-Akhira, 286 seq.

Cherchel, 88, 92 seq., I I 3

Colomb-Béchar, 240

Constantine, 83, I03, I36, 178 seq., 245

Djebel-Chénoua, 97

Djerba, $5^{8}$

Djurjura, the, 28, 180, 298, 301

El-Kantara, 201

El-Mzab, 43, 234

Fort National, 298, $30 \mathrm{I}$

Foum-ês-Sahara, 201

Gouraya, I I 3

Guelma, I 90

Isly, the, $\mathbf{I}^{2} 2$

Isser, the, I 79

Jardin d'Essai, ro4 seq.

Kairouan, 6o

Khabylia, I 43, I 78, $298 \mathrm{seq}$.

Khenchela, 252

Kherrata, 288

La Macta, I 35

Lambessa, II 3, 247, 252 , 279

La Sikkah, I 37

Mansoura, I 64 seq.

Marengo, 88, 90

Mascara, I 35, I 36

Matifou, Cap, 6r, 97

U 


\section{Index}

Medea, 59, I 33

Medrassen, the, 198

Ménerville, 179

Metidja, the, I 45, I 79

Miliana, I 36

Mustapha Supérieur, 27, 109 seq.

Oran, 56, 59, 83, I 03, I 34, I 43, I 49, I $72 \mathrm{seq}$.

Oudjda, 59

Oued Atmenia, 257

Oued Fedhala, I 98

Oued Rir, 232

Palestro, I 79

Roumel, the, I 80 seg.

Sahara, the, 43,82 seq., I 44, 201 seq., 228 seq.

Sahel, the, 82, 97, 179

Sbeitla, 3 I
Sétif, I 78, I 80, $285 \mathrm{seq}$.

Sidi Bel Abbès, 150

Sidi Bou Medine, I 70 seq.

Sidi Ferruch, 129

Sidi Okba, 22 I seq.

Tafna, the, ${ }^{3} 3^{8}$

Taguine, I4 I

Tchad, Lake, 239

Tebessa, 245, 247, 279,280

Tell, the, $82,85,143$

Temacin, 232

Timbuctoo, 235, 239

Timgad, 187,243 seq.

Tipasa, 95 seq.

Tizi-Ouzou, 298, 302

Tlemçen, 53, 59, I I 7, 136 , $148 \mathrm{seq}$.

Tobna, 223

Tombeau de la Chrétienne, 89, 198

Touggourt, 216,232

Tubusuctu, 26 I 


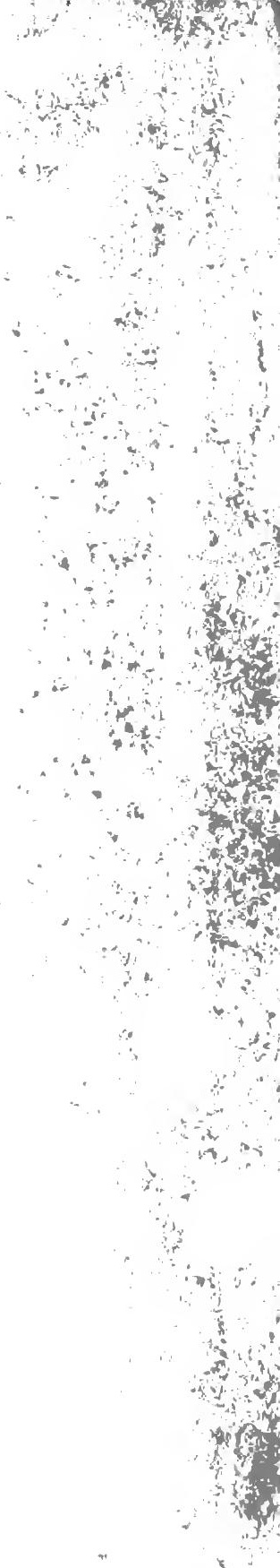


DT

280

T4
Thomas-stanford,

Charles, 1858-1932

About Algeria; Algiers, Tlemcen, Constantine, Biskra, Timgad. J. Lane (1912)

\section{PLEASE DO NOT REMOVE}

CARDS OR SLIPS FROM THIS POCKET 
Q.

5.1.

5.

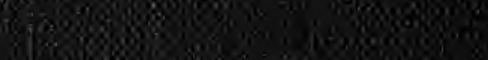

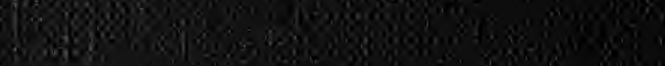

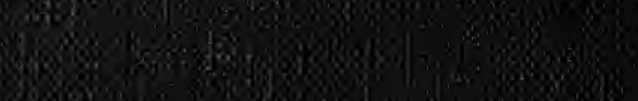

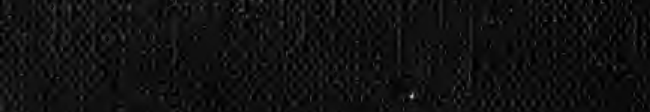

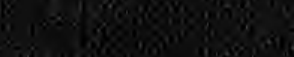

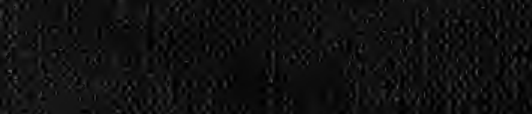

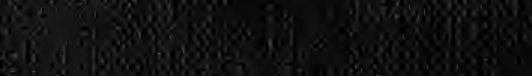

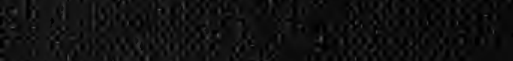

1.8.

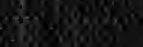

(5)

S)

328

3.

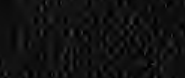

$\operatorname{sig} 60 \%$

*.

$4 \sin ^{2} \sin ^{2}$

3070,80

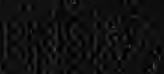

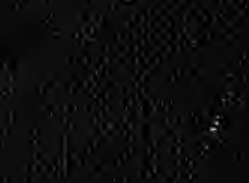

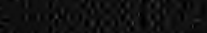

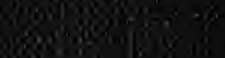

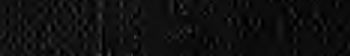

ing

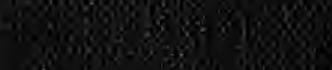

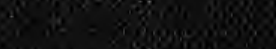

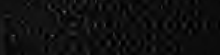

$\cos ^{2}$ 